UNVERSIDADE DE SÃO PAULO

INSTITUTO DE GEOCIÊNCIAS

\title{
COMPORTAMENTO DE ÍONS E SUA ASSOCIAÇÃO A RESÍDUOS DE INDÚSTRIA SIDERÚRGICA EM MANGUEZAL DO SISTEMA ESTUARINO DE SANTOS - CUBATÃOISP.
}

Silvia Cremonez Nascimento

Orientador: Prof. Dr. Raphael Hypolito

TESE DE DOUTORAMENTO

Programa de Pós-Graduação em Recursos Minerais e Hidrogeologia

SÃO PAULO

2007 
Is there a time for keeping your distance A time to turn your eyes away Is there a time for keeping your head down For getting on with your day.......

(Miss Sarajevo -U2) 
É muito bom passar por uma jornada e ter tanto a agradecer, e querer a tantos homenagear. É muito bom dizer obrigada a tanta gente que, neste período, em que se é acometido de tantos surtos de tristeza, incapacidade, euforia, incerteza, cansaço, alegrias, conseguiu se manter simplesmente presente. Por isso, as homenagens:

Ao CNPq, agradeço pela bolsa concedida e pelo auxílio financeiro (Processo $\mathrm{n}^{\circ}$ $141391 / 2003)$;

Ao Curso de Pós-Graduação em Recursos Minerais e Hidrogeologia do Instituto de Geociências da Universidade de São Paulo por toda infraestrutura colocada à disposição;

Ao meu orientador Prof. Dr. Raphael Hypolito mais que um professor, um amigo com quem interagi tantos anos e com quem participei de lutas que me trouxeram cada vez mais experiência e amadurecimento e, sem dúvida, um professor no sentido profundo da palavra;

Ao Élio Lopes e Ministério Público do Estado de São Paulo - Curadoria do Meio Ambiente/ Promotora de Justiça da Comarca de Santos pela colaboração sem a qual este projeto não teria se concretizado;

Aos funcionários Lucia Helena, Gisele e Alyne (CEPAS) pelas análises químicas;

À Ana Paula e Magali e Tadeu secretários da Pós-Graduação, pela simpatia e disposição em ajudar;

À Cristiane, amiga de longa data, sempre prestativa, amiga recentemente adquirida Luciana, que também contribuiu na construção do abstract;

Aos amigos Cristiane e Claudio, Janaina e Sérgio, Anísia e George, que acompanharam diversas etapas deste trabalho cada um com seu diferente grau de ajuda, mas que sempre estiveram ao meu lado incentivando e apoiando;

À Equipe do Laboratório de Hidrogeoquímica III: Claudia, Janaína, Sibele, Marisa, passamos por muitos desafios, momentos difíceis em que várias vezes achamos que não vamos conseguir. Mas consegui e vocês foram meu apoio em vários momentos. E aos novos integrantes: Vinícus, Fernando, Robercal, Daniela e Bruna;

Ao meu "pupilo" André Ribeiro que colaborou nos trabalhos de campo e para várias publicações;

Ao amigo Flavio Monteiro pelo auxílio nas coletas de água do Mar;

Às amigas da UAPGeo: Paula $(\pi)$, Aline, Cintia (Cídia), Roseane (Rossana), Márcia, Lucelene (Wau) e Deborah (Comuna), que me "aturam" todos os dias, vocês ficarão para sempre na memória, tantos momentos partilhados, com simples palavras ou sutil silêncio ou a inacreditável loucura, a vocês minha gratidão por tanta filosofia, tanta alegria e amizade;

Aos meus amigos da Pós-Graduação: Gaston (Edir), Josiane (Jô), Fabrício, Glorinha, Marcelo Rocha, Valéria, Veridiana, Rogério, Adriana (Bisteca), July e Luís pessoas que 
passaram e passam pelo que eu passei e passo: ficar longe da família em busca de um ideal comum;

Às amigas Karine, Janaina Marques e Andreza que torceram pelo meu êxito, o meu sincero agradecimento;

Aos mais novos amigos: Silvia, João Paulino, Flavio Teramatsu, Domingos, Faé, Lissandra, Claudia Algemima, Tati, Michele, Bruno, Ricardo, Eduardo (Deby), Camila, Silvia Alvarez, Bianca e Shigueo que acompanharam somente algumas etapas, mas de alguma forma colaboraram no desenvolvimento deste estudo;

Às tias Abgayl, Amélia, Augusta e Maria Helena; aos tios Donizeti, César, Luiz e Neves e primos Márcia, Fernando, Carla ,Luiz, Tânia e Matheus que apesar da distância física em que nos encontramos, sempre estivemos unidos. E graças a essa união, obtive todo apoio e incentivo necessários, em todo e qualquer momento, para desenvolver mais esta etapa;

Com um carinho muito especial ao Gilberto por toda a paciência, disponibilidade, atenção e colaboração durante a execução deste trabalho a quem qualquer agradecimento será pouco;

E finalmente considero que a elaboração de uma tese é um produto coletivo e graças a Deus e ao carinho de amigos e família foi possível a conclusão de mais esta etapa em minha vida. 


\section{ÍNDICE}

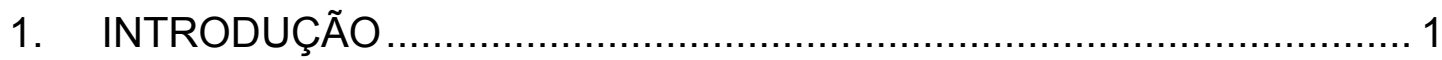

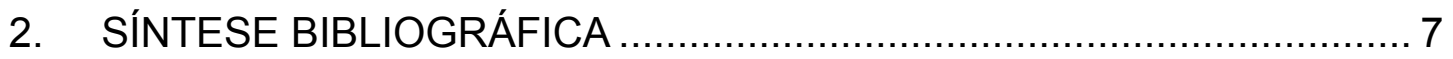

2.1. Íons Metálicos em Ambientes Estuarinos e MANGUEZAL ................ 7

2.2. GeOQuímica e Comportamento dos ÍONS METÁlicos DE INTERESSE. 12

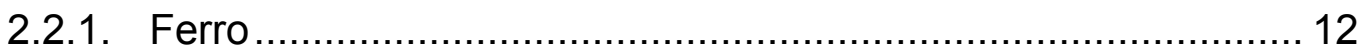

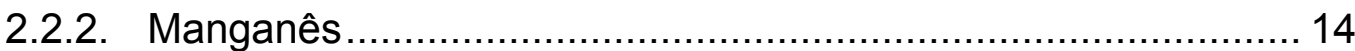

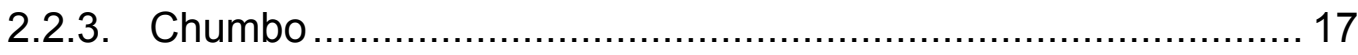

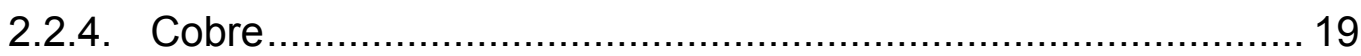

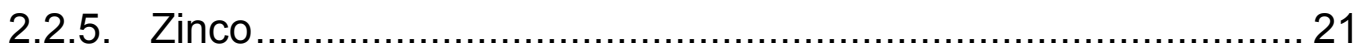

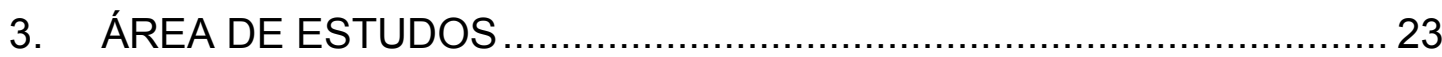

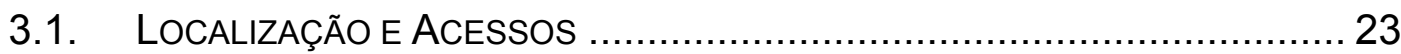

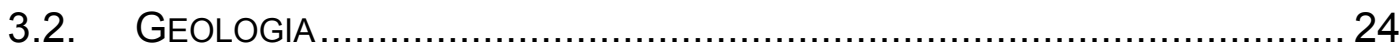

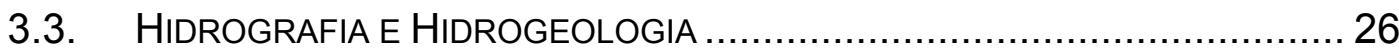

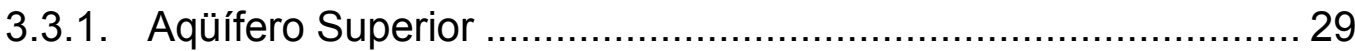

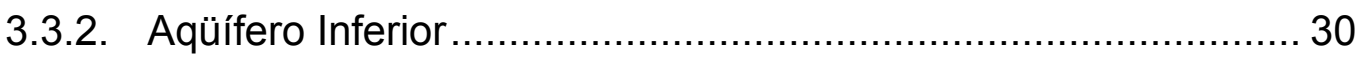

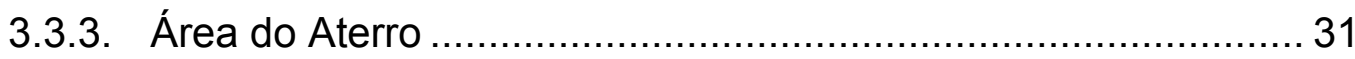

3.4. VEGETAÇÃO GEOMORFologiA E CLIMA ............................................. 32

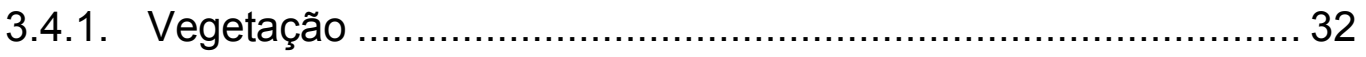

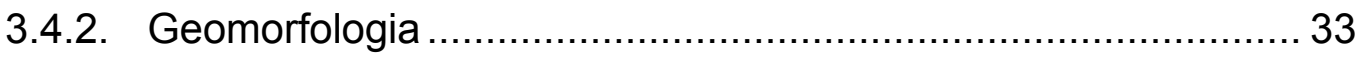

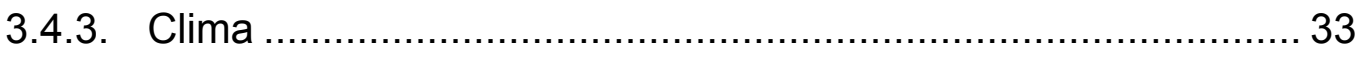

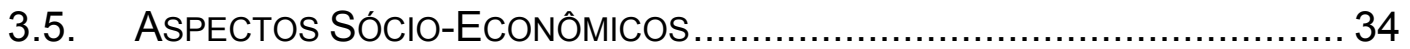

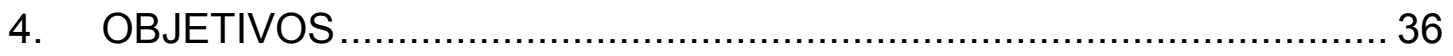




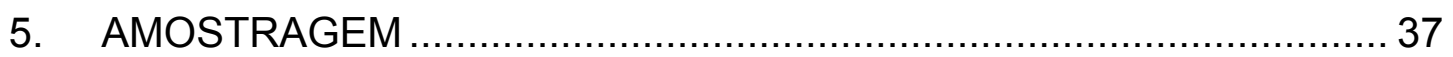

5.1.1. Águas Subterrâneas e Superficiais ......................................... 41

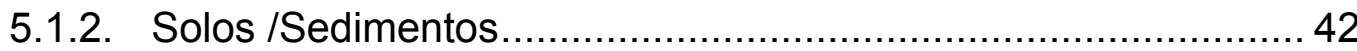

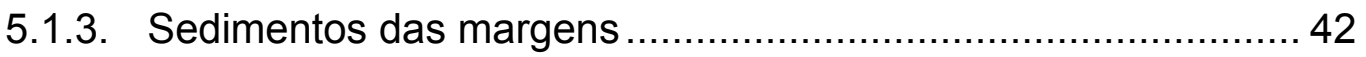

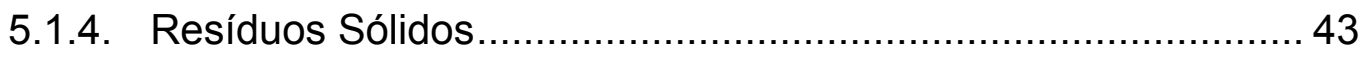

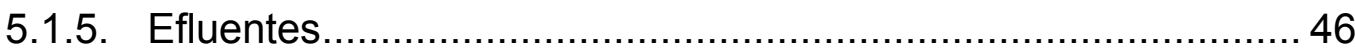

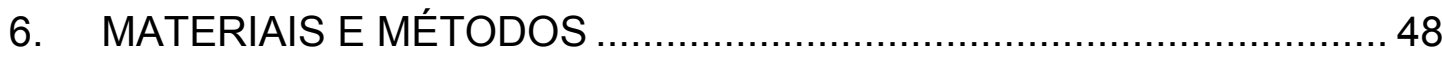

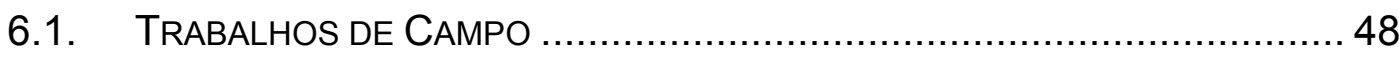

6.1.1. Águas Subterrâneas e Solos/sedimentos associados aos poços.. 48

6.1.2. Águas Superficiais e Sedimentos da Margem do Rio Piaçaguera. 49

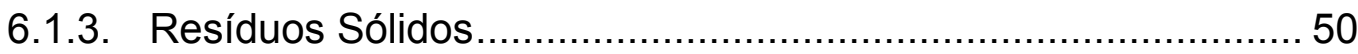

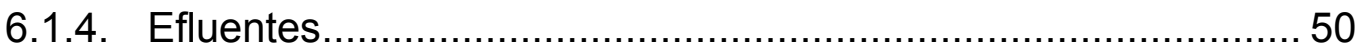

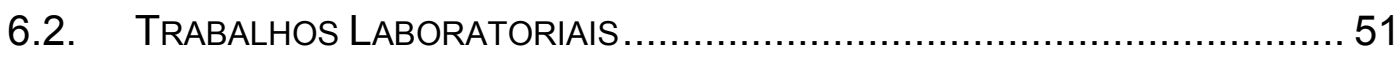

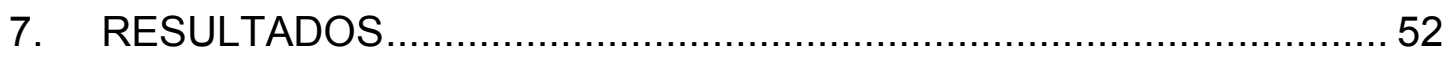

7.1. PaRÂmetros Físico-Químicos Medidos em CAMPo .........................52

7.2. ANÁlises QuímicAs Águas SUPERFICIAIS, SubTERRÂNEAS E EFLUENTES 54

7.3. Análise Granulométrica de Sedimentos da margem do Rio

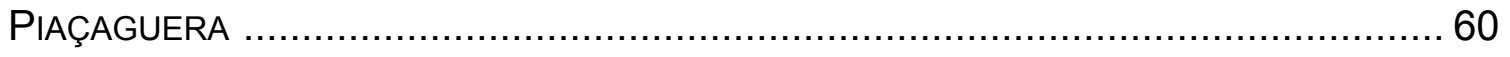

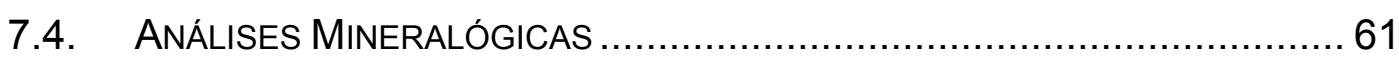

7.5. CAPACIDADE DE TROCA CATIÔNICA .............................................. 70

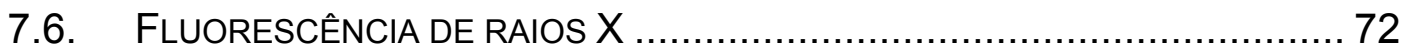

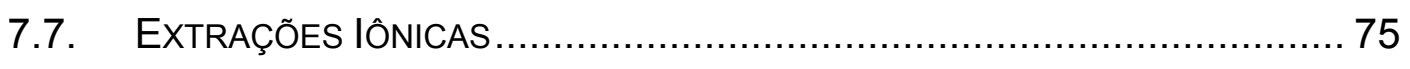


7.7.1. Ácido Nítrico

7.7.2. Extração com Extrator do Tipo Soxhlet ................................... 81

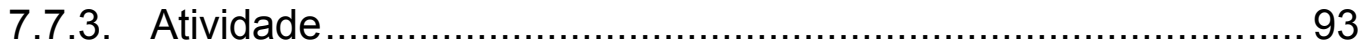

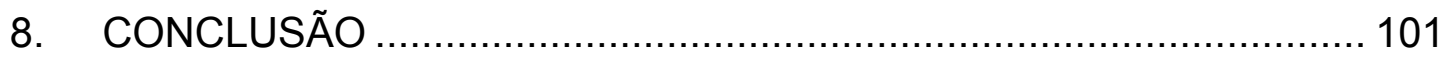

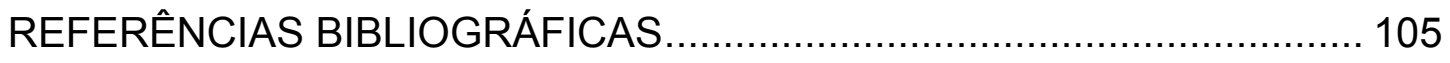




\section{ÍNDICE DE FIGURAS}

Figuras 1-1.(a).: Foto do minério de ferro (hematita) e coque (fundente) para abastecer Altos Fornos. (b): Desenho esquemático de um Alto- Forno................... 3

Figura 1-2.: Seções de lingotamento contínuo $(\mathrm{mm})$................................. 5

Figura 3.1-1 - Localização da área de estudos no Município de Cubatão -

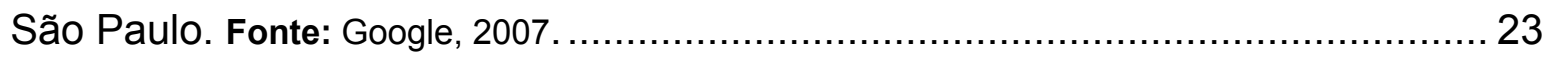

Figura 3.3-1.: Principais Rios da Área de Estudos. Fonte: www.cetesb.sp.gov.br, 2007

Figura 3.5-1.: Vista parcial do Bairro Vila Parisi, como exemplo da falta de planejamento da ocupação do solo. Fonte: Gutberlet, 1996. 35

Figura 5.1-1 ( $\mathbf{a}, \mathbf{b})$.: Fotos mostrando a adaptabilidade da vegetação junto ao aterro formado pelo descarte de resíduos siderúrgicos. 38

Figura 5.1-2: Localização dos pontos de amostragem no Aterro Industrial. Fonte: Google, 2007 40

Figura 5.1.1-1: Poço de monitoramento (PM 2) no Aterro Industrial 41

Figura 5.1.1-2.: Coleta de amostra de água superficial e sedimento da margem do Rio Piaçaguera 42

Figuras 5.4.1-1.a : Coleta na pilha de resíduos de lama de aciaria (R2) b: Coleta na pilha de resíduos (R3) de materiais ricos em escórias 44

Figura 5.4.1-2.(a).: Coleta de Resíduos (R1) na célula do Aterro . (b): Amostragem em vários pontos da célula que constituíram em uma amostra composta 45

Figura 5.4.1-3.: Amostras de Escória (ES) armazenadas na área do Aterro Industrial 46

Figura 5.1.5-1.: Tanque para coleta de percolado da Célula do Aterro Industrial (EF1) 47 
Figura 6.1.1-1: Coleta de água subterrânea do poço de monitoramento PM-1 com amostrador tipo bayler. 49

Figura 7.2-1. a-e: Diagramas $\mathrm{pH}=\mathrm{f}(\mathrm{Eh})$ de compostos de ferro, manganês, cobre, chumbo e zinco à $25^{\circ} \mathrm{C}$ e 1 atm., com projeção dos valores das águas subterrâneas (PM1 a PM5), águas superficiais (As1 e As2) e efluentes (EF1 e EF2). Fonte: modificado de Garrels et al., 1965; Hypolito, 1980 e Brookins, 1988. 59

Figura 7.3-1: Projeção das amostras de sedimentos da margem do Rio Piaçaguera em Digrama Triangular de Sheppard (1965). 60

Figuras 7.4-1. a e b: DRX de sedimentos da margem do Rio Piaçaguera a jusante (a) e a montante dos limites do Aterro (b).

Figura 7.4-2.: Difratometria de Raios $X$ da amostra do minério de ferro utilizado pela Siderúrgica como matéria prima para fabricação do aço. 63

Figuras 7.4-3. a, b, c: Amostras de resíduos depositados na célula do Aterro (R1), e daqueles dispostos na área formando pilhas (R2) (R3) . 65

Figura 7.4-4.: Amostra escória produzida no processo de obtenção do ferro gusa 66

Figura 7.4-5.: Difratograma de amostra de lodo (LD) depositado no tanque de armazenamento de percolado da célula do Aterro.

Figura 7.4-6. a, b, c, d: Difratogramas das amostras de solos/sedimentos associados aos poços de monitoramento (PM1 a PM4) na área do Aterro. ......... 70

Figura 7.7.1-1: Amostras de resíduos descartados na área do Aterro......... 77

Figura 7.7.2-1: Extrator do tipo soxhlet utilizado nas lixiviações com $\mathrm{H}_{2} \mathrm{O} / \mathrm{CO}_{2}$ nas amostras de resíduos siderúrgicos 82

Figuras 7.7.2-2. (a, b) à 7.7.2-9. (a,b): Representação gráfica dos teores de sódio, potássio e pH das soluções obtidas pela lixiviação (soxhlet) das amostras de resíduos depositados na área do Aterro. 88

Figura 7.7.3-1.: Agitador horizontal com amostras de resíduos siderúrgicos em contato com soluções com forças iônicas variadas (AD, IM e AM). 97 


\section{ÍNDICE DE TABELAS}

Tabela 2.1-1: Sumário dos minerais sulfídricos comuns e seus produtos de oxidação (Maia, 2004). 10

Tabela 7.1-1: Parâmetros físico-químicos das águas dos poços de monitoramento (PM1 a PM5) 52

Tabela 7.1-2.: Dados físico-químicos, a montante (As1) e a jusante (As2), das águas do Rio Piaçaguera 52

Tabela 7.1-3.: Medidas físico-químicas dos efluentes depositado no tanque (EF1) e da tubulação de descarte no Rio Piaçaguera (EF2).

Tabela 7.2-1: Análises Químicas dos cátions de interesse $\left(\mathrm{mg} \mathrm{dm}^{-3}\right)$ das amostras de águas subterrâneas (PM1 a PM5), superficiais (As1 e As2) e efluentes (EF1 e EF2) da área do Aterro Industrial e respectivos valores orientadores 1

Tabela 7.2-2: Análises Químicas dos ânions de interesse (mg dm -3) das amostras de águas subterrâneas (PM1 a PM5), superficiais (As1 e As2) e efluentes (EF1 e EF2) da área do Aterro Industrial 1

Tabela 7.3-1.: Resultados das análises granulométricas de sedimentos da margem do Rio Piaçaguera coletadas a montante (Sd1) e jusante (Sd2) nos limites do Aterro. 60

Tabela 7.5-1: Resultados de CTC e de matéria orgânica dos sedimentos da margem do Rio Piaçaguera 71

Tabela 7.6-1.a.: Análises químicas dos constituintes maiores e menores das amostras de matérias primas utilizadas na fabricação do aço. 72

Tabela 7.6.-1.b.: Análises químicas das amostras de resíduos gerados na fabricação do aço. 73 
Tabela 7.6-1.c.: Análises químicas das amostras de solos/sedimentos associados aos poços de monitoramento (S1 a S4) e sedimentos da margem do Rio Piaçaguera (Sd1 e Sd2) ....................................................................... 73

Tabela 7.7.1.-1.a.: Extração seletiva das amostras de resíduos descartados na área do Aterro Industrial, utilizando ácido nítrico (8M) 76

Tabela 7.7.1.-1.b.: Extração seletiva das amostras de solos/sedimentos (S1 a S4) associados aos poços de monitoramento e sedimentos da margem do Rio Piaçaguera (Sd1 e Sd2), utilizando ácido nítrico (8M) ........................................ 76

Tabelas 7.7.2-2 a, b, c, d, e, f, g, h: Dados analíticos de sódio e potássio $\left(\mathrm{mg} \mathrm{dm}{ }^{-3}\right)$ e $\mathrm{pH}$ das soluções obtidas por extração soxhlet das amostras de resíduos descartadas na área do Aterro. 83

Tabela 4.7.2-10: Teores dos cátions, de interesse, obtidos através de extrações seletivas (soxhlet). 1

Tabela 4.7.2-11:Teores dos ânions, de interesse, obtidos através de extrações seletivas (soxhlet) 91

Tabela 7.7.3-1.: Valores de Força lônica (I) calculados para a água subterrânea coletada em poços de monitoramento na área do Aterro Industrial. . 96

Tabela 7.7.3-2: Análise Química $\left(\mathrm{mg} \mathrm{dm}^{-3}\right)$ da água do mar (AM) coletada próxima á área de estudos utilizada nos ensaios laboratorias . 96

Tabela 7.7.3-3.: Valores de potencial hidrogeniônico $(\mathrm{pH})$, potencial redox (Eh), condutividade elétrica (CE) e força iônica (I) das soluções em contato com os resíduos em experimentos sobre comportamento sólido/solução. 97

Tabela 7.7.3-4.: pHs finais e respectivas condutividade elétrica $\left(\mathrm{mS} \mathrm{cm}^{-1}\right)$ em ensaios de sólidos/soluções com força iônica variada 98

Tabela 7.7.3-5.a: Monitoramento analítico dos cátions $\left(\mathrm{mg} \mathrm{dm}^{-3}\right)$ em ensaios de força iônica nas amostras de resíduos siderúrgicos e solos/sedimentos associados ao poços de monitoramento da área do Aterro Industrial. 98 
Tabela 7.7.3-5.b: Monitoramento analítico dos ânions $\left(\mathrm{mg} \mathrm{dm}^{-3}\right)$ em ensaios de força iônica nas amostras de resíduos siderúrgicos e solos/sedimentos associados ao poços de monitoramento da área do Aterro Industrial................... 99

Tabela 7.7.3-6.: Força iônica $\left(\mathrm{mol} \mathrm{dm}^{-3}\right)$ e $\Delta \mathrm{pH}$ de soluções obtidas em ensaios de resíduos do Aterro Siderúrgico com força iônica variada..................... 99 


\section{RESUMO}

O sistema estuarino de Santos, situado em Cubatão, representa um dos mais importantes exemplos brasileiros de degradação ambiental por poluição de origem industrial do país. Entre as atividades industriais geradoras de resíduos do estuário, destaca-se a indústria siderúrgica, de especial interesse nesse trabalho.

O minério de ferro utilizado para a fabricação do aço é constituído essencialmente de hematita e no processo siderúrgico ele é fundido em altosfornos utilizando calcário como fundente e carvão mineral como redutor. Esse processo origina o ferro gusa tendo como impurezas carbono, silício, enxofre, fósforo, manganês etc. $O$ ferro fundido assim obtido por meio do resfriamento desta mistura é muito quebradiço, não podendo ser utilizado, e a adição de alguns elementos como manganês, cobre e chumbo produzem aços com propriedades especiais e auxiliam na eliminação de impurezas.

Os insumos utilizados nos processos siderúrgicos resultam em subprodutos que são diariamente descartados em área de manguezal que, como se sabe, são sistemas funcionalmente complexos, que se desenvolvem na zona de contato das águas marinha e fluvial.

Esta área serviu para descarte de resíduos durante um período de aproximadamente 30 anos e somente a partir da década de 90 a CETESB exigiu a instalação do Aterro. Desta forma, não há possibilidade de se ter comportamento uniforme relacionado à disponibilidade iônica para o meio ambiente.

Neste trabalho os dados analíticos indicaram baixa mobilidade iônica dos resíduos sólidos e que ocorrem de modo intermitente.

Resultados de estudos experimentais em colunas de lixiviação, simulando água de chuva, e submetendo os resíduos à diferentes condições de força iônica, comparados com os fenômenos que ocorrem no meio natural, permitiram concluir que as águas pluviométricas têm menor influência e o fator decisivo para a disponibilidade iônica são $\mathrm{pH}$ e as variações dos níveis d'água em função das marés. 


\section{ABSTRACT}

The estuarine system in Santos, located in Cubatão, is one of the most important Brazilian examples of environmental degradation caused by the pollution from Brazilians industries. Among the industries that dispose waste into the sewage, the steel mill stands out, and that is the reason why it the subject of this project.

The iron ore used to produce the steel is a compound essentially of hematite and in its manufacture, it is casting in great temperature ovens by using calcareous to casting and coal to reduce. This process produces iron that is compound of impure carbon, silicon, sulphur, phosphorus, manganese and so on. The cast iron obtained by cooling this mixture has low resistance to break so it is no longer used, and the impurity are later removed by adding some elements as manganese, copper and lead and that produces steel with special properties.

The incomes used in the manufacture of steel generates others products that are daily disposed in the fenland with no specific requires that, as known, are complex systems which develop in the contact area of the sea water and the fluvial one.

In this land waste was disposed during 30 years and only after the 90's, CETESB demanded the landfill project. So, there is no stable behavior of the availability of ions to the environment.

The analytical data show low mobility of the ions and that it occurs in an intermittent way.

The result from the experimental studies in a column that leached, which simulates the rain water moving through the waste in several conditions of ion strength, compared to the what happens in natural environment, concluded that the sea water and $\mathrm{pH}$ has lower influence and the reason for that is because the availability of ions are the variation of the water table according to tidal influence. 
It is proved that iron ions, manganese, copper, lead and zinc are constantly being freed which is a great hazard to the bioaccumulation once the fenland is one of the most productive ecosystems of the planet. 


\section{INTRODUÇÃO}

No sistema estuarino de Santos e São Vicente encontra-se aproximadamente $43 \%$ dos $231 \mathrm{~km}^{2}$ de manguezais da Costa Paulista (Herz, 1991). Levantamento do estado de conservação dos manguezais nesta região, baseado em fotografias aéreas do período compreendido entre 1958 e 1989, demonstrou que $44 \%$ encontravam-se degradados e $16 \%$ haviam sido aterrados para ocupação urbana ou industrial, sendo apenas $40 \%$ mantidos em bom estado de conservação (Silva et al., 1981). No Município de Cubatão restam apenas 17\% da área de cobertura de manguezais $\left(29 \mathrm{~km}^{2}\right)$ em bom estado.

Os estuários são encontrados em todos os tipos de clima e condições de maré sendo melhores desenvolvidos em planícies costeiras de média latitude (Olausson \& Cato, 1980). Atualmente, o conceito mais utilizado sobre o que constitui um estuário é o de um corpo d'água costeiro semi-fechado com livre acesso ao oceano no qual a água do mar é diluída por águas doces da drenagem terrestre (Reinson, 1992) e Manguezal, por sua vez, é um ecossistema de transição entre ambientes marinho e terrestre que ocupa a zona de intermaré dos estuários (Amaral, 2003).

Os manguezais se distribuem na faixa tropical-subtropical entre os Trópicos de Câncer e Capricórnio e em algumas ocorrências de bosques de mangue em latitudes mais altas, no entanto, neste caso, com menor desenvolvimento estrutural (Citron e Schaeffer-Novelli, 1983); na costa brasileira é encontrado desde o extremo norte, no Rio Oiapoque $\left(04^{\circ} 20^{\prime} \mathrm{N}\right)$, até o litoral centro-sul catarinense, Laguna ( $28^{\circ} 30^{\prime}$ 's) (Amaral, op.cit.).

O substrato deste ecossitema é constituído por sedimentos lodosos ricos em matéria orgânica, onde ocorre o desenvolvimento de flora típico, representado por associação de árvores e arbustos (Ex: Rhyzophora mangle, Avicena sp.), adaptada às variações de salinidade e baixos teores de oxigênio (Sugio, 1998).

Os sistemas estuarinos de Santos e São Vicente, inseridos na Região Metropolitana da Baixada Santista, Estado de São Paulo, representam um dos 
mais importantes exemplos brasileiros de degradação ambiental. Esta degradação afeta o meio ambiente por poluição hídrica e atmosférica de origem industrial em ambientes costeiros.

A região abriga o mais importante Porto da América Latina (Porto de Santos), bem como o maior Pólo Industrial do país, situado em Cubatão.

O Pólo Industrial de Cubatão é apontado como principal contribuinte no processo de degradação na região da Baixada Santista que se dá através de aterramento de manguezais para ocupação urbana e industrial, lançamento de efluentes tóxicos, disposição de resíduos sólidos industriais e domésticos, além de freqüentes acidentes com derramamentos de óleo, substâncias tóxicas etc.

Apesar de todos os esforços desprendidos pelas indústrias locais no programa de controle de poluição desencadeados pela CETESB em 1983, o histórico ambiental negativo resultou numa carga de poluente superior à capacidade de assimilação do estuário. Estes poluentes, altamente tóxicos, acumularam-se nos sedimentos transformando-se em fontes de contaminantes que se somam àqueles gerados pela descarga das indústrias contaminando organismos aquáticos constituindo-se em perigo latente à saúde pública.

Entre as atividades industriais geradoras de resíduos do Pólo Industrial de Cubatão destaca-se a indústria siderúrgica de base, de especial interesse nesse trabalho, que por utilizar metais diretamente como matéria prima, libera para o meio ambiente ampla variedade de produtos poluentes, dentre os quais metais pesados.

A disposição de resíduos sólidos, oriundos dos diferentes processos industriais siderúrgicos, vem sendo realizada já há mais de três décadas no manguezal de Cubatão-São Paulo; por exigências legais esses resíduos serviram de sustentação para que se implantasse um Aterro Industrial somente na década de 90 .

A indústria siderúrgica instalada na área de estudos utiliza como matéria prima minério de ferro (hematita) que é inicialmente beneficiado em alto-fornos, 
nos quais são adicionados, em sua parte superior, junto ao minério de ferro, calcário $\left(\mathrm{CaCO}_{3}\right)$, coque e na base ar ou oxigênio pré-aquecido (Figuras 1-1 a, b).

a)
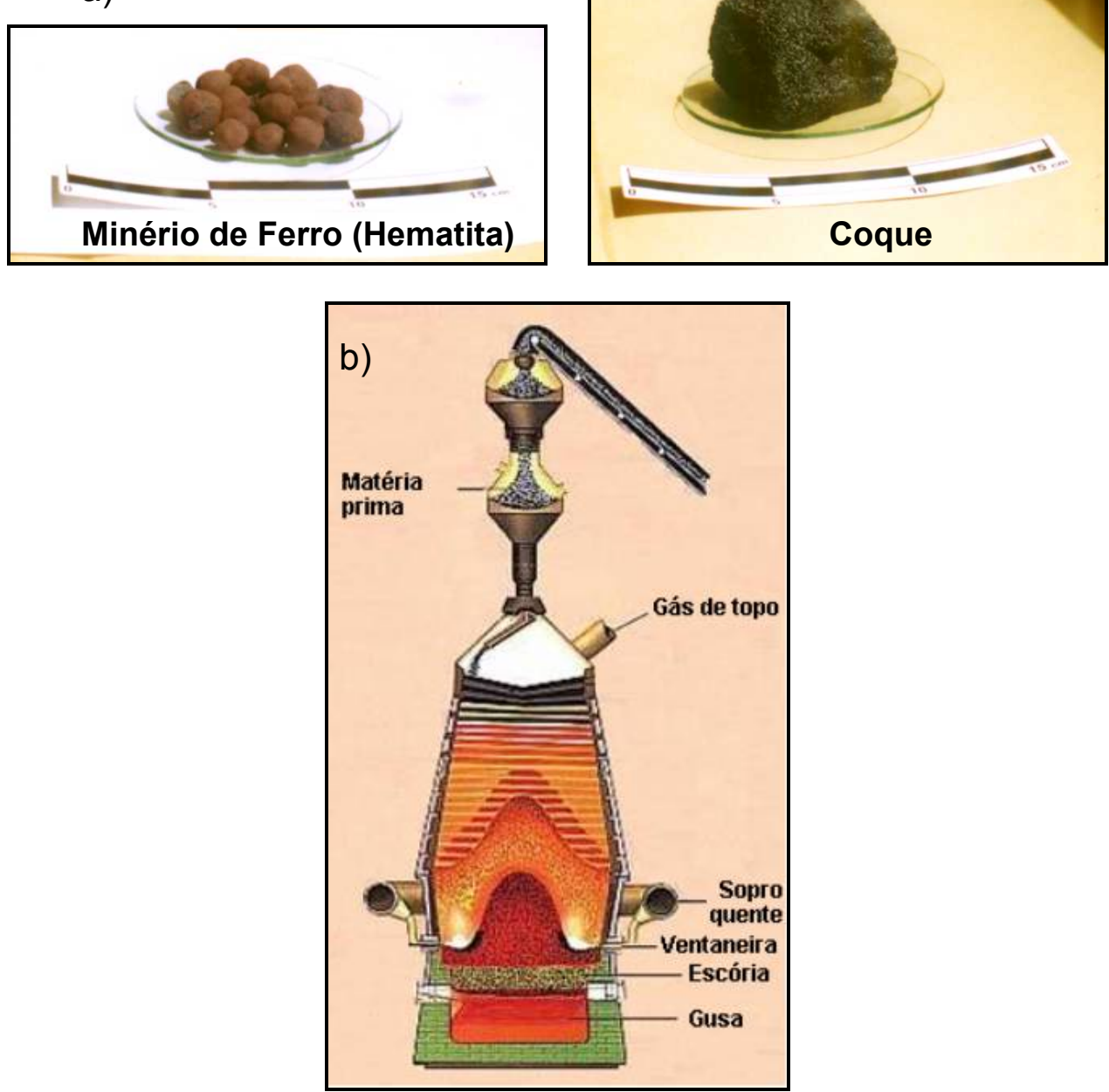

Figuras 1-1.(a).: Foto do minério de ferro (hematita) e coque (fundente) para abastecer Altos Fornos. (b): Desenho esquemático de um Alto- Forno.

À medida que a carga se deposita no forno o coque reage com o oxigênio formando monóxido de carbono e o calor liberado faz com que a temperatura se eleve chegando acima de $1900^{\circ} \mathrm{C}$.

No topo do forno, onde a temperatura é mais baixa $\left(350^{\circ} \mathrm{C}\right)$, o minério de ferro é reduzido para $\mathrm{Fe}_{3} \mathrm{O}_{4}$ e, em seguida, a ferro metálico (Sienko, 1977): 


$$
\begin{gathered}
3 \mathrm{Fe}_{2} \mathrm{O}_{3}(\mathrm{~s})+\mathrm{CO}(\mathrm{g}) \rightarrow 2 \mathrm{Fe}_{3} \mathrm{O}_{4}(\mathrm{~s})+\mathrm{CO}_{2}(\mathrm{~g}) \\
\mathrm{Fe}_{3} \mathrm{O}_{4}(\mathrm{~s})+\mathrm{CO}(\mathrm{g}) \rightarrow 3 \mathrm{FeO}(\mathrm{s})+\mathrm{CO}_{2}(\mathrm{~g}) \\
\mathrm{FeO}(\mathrm{s})+\mathrm{CO}(\mathrm{g}) \rightarrow \mathrm{Fe}(\mathrm{s})+\mathrm{CO}_{2}(\mathrm{~g})
\end{gathered}
$$

Concomitantemente a essas reações de redução que envolvem o minério de ferro, ocorrem também reações relevantes como a do $\mathrm{CaCO}_{3}$ que se transformam em $\mathrm{CaO}$ e $\mathrm{CO}_{2}$, que com excesso de coque produz mais $\mathrm{CO}$ :

$$
\begin{gathered}
\mathrm{CaCO}_{3}(\mathrm{~s}) \rightarrow \mathrm{CaO}(\mathrm{s})+\mathrm{CO}_{2}(\mathrm{~g}) \\
\mathrm{C}(\mathrm{s})+\mathrm{CO}_{2}(\mathrm{~g}) \rightarrow 2 \mathrm{CO}(\mathrm{g})
\end{gathered}
$$

$\mathrm{O} \mathrm{SiO}_{2}$ e $\mathrm{Al}_{2} \mathrm{O}_{3}$, presentes como impurezas do minério de ferro, reagem com - $\mathrm{CaO}$, formando $\mathrm{CaSiO}_{3}$ e $\mathrm{Ca}\left(\mathrm{AlO}_{2}\right)_{2}$ (Sienko, 1977). Estas reações são importantes, uma vez que facilitam a remoção de impurezas contendo sílica e alumínio. $\mathrm{O} \mathrm{CaO}$, sendo óxido básico, reage com $\mathrm{SiO}_{2}$ formando silicato de cálcio $\left(\mathrm{CaSiO}_{3}\right)$ que sob a forma de escória se deposita no fundo do forno, onde flutua sobre o ferro fundido.

Próximo à base do forno, a temperatura acha-se em tono de $1930^{\circ} \mathrm{C}$ que funde tanto o ferro como a escória, formando duas camadas distintas que podem ser removidas separadamente. Para cada tonelada de ferro produzida, há formação de meia tonelada de escória (Sienko, op.cit ; Burgess, 1995).

O produto bruto que sai dos altos fornos, com cerca de $4 \%$ de carbono, $2 \%$ de silício, traços de enxofre e até $1 \%$ de fósforo e manganês, é chamado ferro gusa ou ferro fundido. O enxofre é, provavelmente, a impureza mais indesejável, por ser de difícil remoção nas operações de purificação e por causar a quebra do aço quando é trabalhado (Sienko op. cit.). 
O ferro gusa que sai do alto-forno é utilizado para produção de ligas, aço inox, aços especiais, aço convencional e, com adição de alguns elementos, obtém-se também aços com propriedades específicas. Quando, por exemplo, adicionado-se ao aço, manganês em pequenas quantidades, ele age como removedor de oxigênio e enxofre do ferro fundido, formando $\mathrm{MnO}_{2}$ e $\mathrm{MnS}$, que são separados da escória evitando, formação de bolhas quando o ferro se solidifica; quando em grandes quantidades, confere ao aço alta dureza e elevada tenacidade.

Após a obtenção do aço inicia-se a moldagem com fabricação de lingotes, toras e tarugos (Figura 1-2.) e incluem-se também o processo de laminação que pode ser efetuado a quente com obtenção de diferentes tipos de produtos e aplicações como placas, chapas, laminados, folhas, barras, trilhos etc. A laminação a frio produz laminados para uso em engenharia e galvanoplastia.

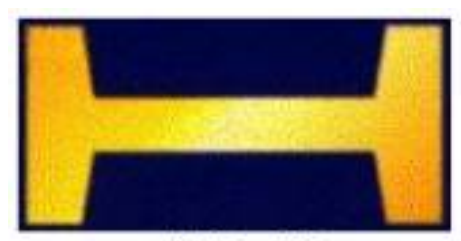

$1048 \times 450$

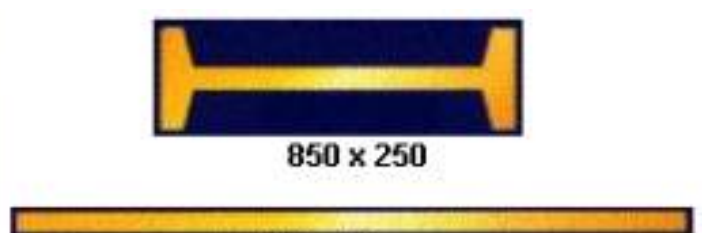

$1680 \times 50$

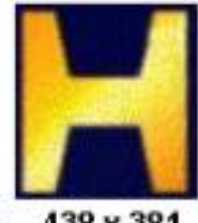

$438 \times 381$

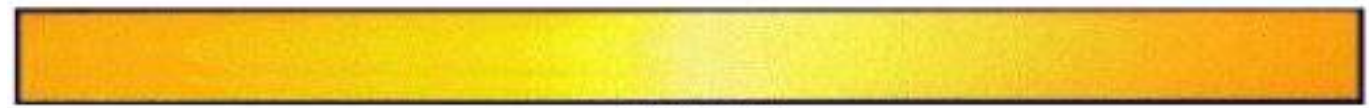

$3200 \times 218$

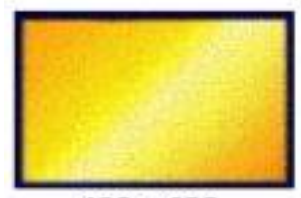

$400 \times 600$

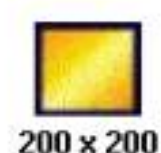

$200 \times 200$

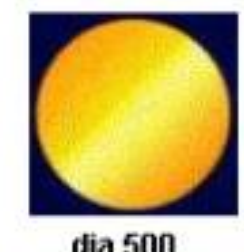

dia 500
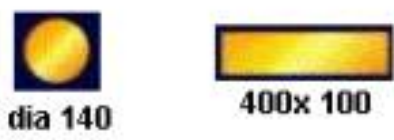

Figura 1-2.: Seções de lingotamento contínuo (mm).

Este é o método mais comum de obtenção do ferro metálico e corresponde a $96 \%$ da produção mundial de ferro. O custo energético é alto e, sem uma política de gestão adequada dos resíduos gerados, o impacto ambiental negativo também é bastante elevado (Kroschwitz, 1995), principalmente pela presença de íons 
metálicos poluentes. Para estudo do comportamento desses íons, selecionou-se como área de estudo, o Aterro Industrial, localizado na Ilha dos Amores, Cubatão, São Paulo, que se encontra em atividade a aproximadamente 20 anos, ocupando uma área útil retangular de aproximadamente $6000 \mathrm{~m}^{2}$ (200 m x $\left.300 \mathrm{~m}\right)$.

O Aterro Industrial encontra-se em área de manguezal, que é um dos sistemas onde têm lugar fenômenos físico-químicos de grande significado científico, os quais ocorrem na coluna líquida, nos sedimentos e na superfície de contato desses dois meios.

Apesar de o Aterro Industrial ter sido construído para receber resíduos inertes, recebendo cerca de 11000 t/mês de resíduos, a área está presente no Cadastro de Áreas contaminadas da CETESB, com indicação de contaminação por metais pesados e outras substâncias (CETESB, 2007).

A nocividade dos metais pesados é sobejamente conhecida, dispensando qualquer justificativa para seu estudo no meio ambiente. Torna-se evidente, desta forma, a grande importância e necessidade de se conhecer, com profundidade, o comportamento dos constituintes desses rejeitos em relação ao impacto ambiental. Os manguezais têm sido, utilizados, em muitos países já há muito tempo como uma alternativa de baixo custo para descarte de resíduos domésticos e industriais, devido sua capacidade de reter metais pesados e de reaproveitar nutrientes destes resíduos. No entanto, apesar do poder de retenção do manguezal, estes elementos acabam atingindo a fauna, flora e, conseqüentemente, a cadeia alimentar tornando-se grave risco também para as populações humanas.

Estudos como este permitem compreensão dos processos hidrogeoquímicos associados às transformações, conseqüentes da disposição desses resíduos industriais siderúrgicos em sedimentos de manguezais, bem como nas águas superficiais e subterrâneas adjacentes. 


\section{SÍNTESE BIBLIOGRÁFICA}

\section{1. Ílons Metálicos em Ambientes Estuarinos e Manguezal}

Manguezal é um ecossistema especial que se desenvolve nas áreas litorâneas tropicais. Ocorre em terrenos baixos, planos, em regiões estuarinas, às margens de lagunas ou ao longo de rios e canais naturais, até onde ocorre o fluxo das marés. Nesses locais a força das marés é branda e a velocidade das correntes é baixa, propiciando intensa deposição de sedimentos finos e matéria orgânica. O substrato formado tem consistência pastosa, pouco compactado, alagadiço, rico em matéria orgânica, pouco oxigenado e sujeito a períodos alternados de inundação e drenagem, conforme variação das marés (IPT, 1988).

Devido aos nutrientes que as águas transportam, é geralmente uma área com elevada produtividade biológica, no entanto, por ser uma região semi-fechada e tratar-se uma área predominantemente de deposição, sofre particularmente os efeitos da poluição.

De acordo com Cintrón \& Schaeffer (1983), os solos desses ecossistemas por se encontrarem em ambientes de baixa energia, apresentam predominância das frações mais finas (argila e silte), elevadas quantidades de matéria orgânica e sais solúveis em função do contato com o mar.

São ambientes anóxicos, favorecidos pela quantidade excessiva de material orgânico e nutrientes, devido à decomposição da serrapilheira que são restos de vegetação, folhas, ramos, caules e cascas de frutos em diferentes estágios de decomposição, bem como de animais, que forma uma camada ou cobertura sobre o solo de uma floresta e devido também à saturação pela água. São solos com cores acinzentadas a pretas, com presença de $\mathrm{H}_{2} \mathrm{~S}$, podendo alcançar vários metros de profundidade, fracamente consolidados e semi-fluidos (Ferreira, 2002).

Nos manguezais a grande produção de serrapilheira resulta em elevadas concentrações de matéria orgânica nos sedimentos, altas concentrações de 
sulfetos - provenientes da água do mar, devido o processo de inundação e ambiente redutor que acabam por atribuir a estes ambientes característica de verdadeiras barreiras geoquímicas ao transporte de poluentes metálicos para o ambiente oceânico adjacente (Barcellos, et. al., 2005).

A inundação a que são freqüentemente submetidos é responsável por importantes alterações físico-químicas nestes solos/sedimentos. Alterações estas que causam queda do potencial redox, aumento dos valores de $\mathrm{pH}$, mudanças drásticas no equilíbrio de minerais e na dinâmica de elementos como ferro e enxofre (Ponnemperuma, 1972).

Em função do alagamento, a taxa de difusão do oxigênio no solo sofre uma diminuição de cerca 10000 vezes, tornando-se muito inferior à demanda microbiana para oxidação da matéria orgânica.

A oxidação da matéria orgânica inicia-se com microorganismos heterotróficos do solo que, através da respiração, oxidam o carbono da matéria orgânica, liberando energia que é utilizada em seus processos metabólicos; em seqüência os microorganismos aeróbios consomem $\mathrm{O}_{2}$ inicialmente presente no solo, tornam-se inativos ou morrem.

Finalmente os microorganismos anaeróbios facultativos obrigatórios que são capazes de proliferar obtendo energia liberada da oxidação da matéria orgânica através da utilização de compostos inorgânicos do solo como aceptores de elétrons $\left(\mathrm{NO}_{3}{ }^{-}, \mathrm{Mn}^{4+}, \mathrm{Fe}^{3+}\right.$ e $\left.\mathrm{SO}_{4}{ }^{2-}\right)$ na decomposição da matéria orgânica $\left(\mathrm{CO}_{2}\right.$, $\mathrm{N}_{2}$ e $\mathrm{H}^{+}$); estas decompõem a matéria orgânica sob condições anaeróbias, reduzindo os íons sulfato a sulfeto e o $\mathrm{Fe}^{3+}$ a $\mathrm{Fe}^{2+}$, levando à formação de pirita $\left(\mathrm{FeS}_{2}\right)$ (Ponnamperuma, 1972).

Segundo Ferreira (2002), a combinação dos elevados conteúdos de matéria orgânica e enxofre com a condição anaeróbia, as fontes de ferro reativo (via aportes de sedimentos inorgânicos) e fontes de $\mathrm{SO}_{4}{ }^{2-}$ prontamente disponíveis, faz dos solos de mangue um ambiente propício à ocorrência da redução bacteriana do sulfato a sulfeto e seu conseqüente acúmulo sob a forma de pirita $\left(\mathrm{FeS}_{2}\right)$. 
Assim, como a drenagem ácida que ocorre em pilhas de rejeitos de mineração, também começou ser investigado tal problema em sedimentos ricos em matéria orgânica e sulfetos (Satawathanonout et al., 1991; Calmano et al. 1993, Borma, 1998; Maia, 2004). Estas reações de oxidação são freqüentemente aceleradas por atividades biológicas, produzem $\mathrm{pH}$ baixo na água com potencial de mobilizar metais que possam estar contidos nos sedimentos.

Os processos da oxidação do sulfeto de ferro pode ser exemplificado pelo processo global de oxidação da pirita:

$$
\mathrm{FeS}_{2}(\mathrm{~s})+15 / 4 \mathrm{O}_{2}(\mathrm{~g})+7 / 2 \mathrm{H}_{2} \mathrm{O}(\mathrm{l})=\mathrm{Fe}(\mathrm{OH})_{3}(\mathrm{~s})+4 \mathrm{H}^{+}(\mathrm{g})+2 \mathrm{SO}_{4}{ }^{2-}(\mathrm{aq})
$$

Esta equação descreve o processo simultâneo de oxidação do $\mathrm{S}$ e do $\mathrm{Fe}^{2+}$ sem considerar o tempo envolvido. A oxidação do sulfeto de ferro, no entanto, acontece em etapas, de acordo com as variações que vão ocorrendo durante o processo e em função do tipo de agente oxidante (Stumm e Morgan, 1981):

\section{Estágios I e II}

$$
\begin{gathered}
\mathrm{FeS}_{2}(\mathrm{~s})+7 / 2 \mathrm{O}_{2}(\mathrm{~g})+\mathrm{H}_{2} \mathrm{O}(\mathrm{l}) \stackrel{\leftarrow}{\rightarrow} \mathrm{Fe}^{2+}(\mathrm{aq})+2 \mathrm{SO}_{4}^{2-}(\mathrm{aq})+2 \mathrm{H}^{+}(\mathrm{aq}) \\
\mathrm{Fe}^{2+}(\mathrm{aq})+1 / 4 \mathrm{O}_{2}(\mathrm{~g})+\mathrm{H}^{+}(\mathrm{aq}) \stackrel{\leftarrow}{\leftrightarrows} \mathrm{Fe}^{3+}(\mathrm{s})+1 / 2 \mathrm{O}_{2}(\mathrm{~g}) \\
\mathrm{Fe}^{3+}(\mathrm{s})+3 \mathrm{H}_{2} \mathrm{O}(\mathrm{l}) \stackrel{\leftarrow}{\leftrightarrows} \mathrm{Fe}(\mathrm{OH})_{3}(\mathrm{~s})+3 \mathrm{H}^{+}
\end{gathered}
$$

Estágio III

$$
\mathrm{Fe}^{2+}(\mathrm{aq})+1 / 2 \mathrm{O}_{2}(\mathrm{~g})+\mathrm{H}^{+} \leftrightarrows \mathrm{Fe}^{3+}(\mathrm{s})+1 / 2 \mathrm{H}_{2} \mathrm{O}(\mathrm{l})
$$$$
\mathrm{FeS}_{2}(\mathrm{~s})+14 \mathrm{Fe}^{3+}(\mathrm{s})+8 \mathrm{H}_{2} \mathrm{O}(\mathrm{l}) \stackrel{\leftrightarrows}{\leftrightarrows} 15 \mathrm{Fe}^{2+}(\mathrm{aq})+2 \mathrm{SO}_{4}{ }^{2-}(\mathrm{aq})+16 \mathrm{H}^{+}
$$

A oxidação química ou biológica da pirita e outros minerais de enxofre ocorrem inicialmente para produzir ácido. $O$ ácido pode ser neutralizado por alguns minerais carbonáticos como calcita e dolomita e/ou minerais silicatados 
como, por exemplo, anortita $\left(\mathrm{CaAl}_{2} \mathrm{Si}_{2} \mathrm{O}_{8}\right)$, presentes no ambiente. A produção de T. ferroxidans aumenta com o decréscimo do $\mathrm{pH}$, e a oxidação bacteriana causa um novo decréscimo do $\mathrm{pH}(<3)$.

Embora a pirita seja um dos minerais mais amplamente citados nos estudos de oxidação, várias outras espécies são freqüentemente encontradas nos produtos resultantes das reações de oxidação como são mostrados na Tabela 2.1-1.

Tabela 2.1-1: Sumário dos minerais sulfídricos comuns e seus produtos de oxidação (Maia, 2004)

\begin{tabular}{|c|c|c|c|}
\hline Mineral & Composição & $\begin{array}{l}\text { Produto após a } \\
\text { completa oxidação }\end{array}$ & $\begin{array}{c}\text { Minerais secundários possiveis formados a } \\
\text { pH neutro após a completa oxidação e } \\
\text { neutralização }\end{array}$ \\
\hline pirita & $\mathrm{FeS}_{2}$ & $\mathrm{Fe}^{3+} ; \mathrm{SO}_{4}{ }^{2-} ; \mathrm{H}^{+}$ & hidróxidos de ferro e sulfatos; gipsita \\
\hline marcasita & $\mathrm{FeS}_{2}$ & $\mathrm{Fe}^{3+} ; \mathrm{SO}_{4}{ }^{2-} ; \mathrm{H}^{+}$ & hidróxidos de ferro e sulfatos \\
\hline pirrotita & $\mathrm{Fe}_{1-x} \mathrm{~S}^{*}$ & $\mathrm{Fe}^{3+} ; \mathrm{SO}_{4}{ }^{2-} ; \mathrm{H}^{+}$ & hidróxidos de ferro e sulfatos \\
\hline smithita; greigita & $\mathrm{Fe}_{3} \mathrm{~S}_{4}$ & $\mathrm{Fe}^{3+} ; \mathrm{SO}_{4}{ }^{2-} ; \mathrm{H}^{+}$ & hidróxidos de ferro e sulfatos \\
\hline mackinavita & $\mathrm{FeS}_{2}$ & $\mathrm{Fe}^{3+} ; \mathrm{SO}_{4}{ }^{2-} ; \mathrm{H}^{+}$ & hidróxidos de ferro e sulfatos \\
\hline amorfo & $\mathrm{Cu}_{2} \mathrm{FeS}_{2}$ & $\mathrm{Fe}^{3+} ; \mathrm{SO}_{4}{ }^{2-} ; \mathrm{H}^{+}$ & $\begin{array}{l}\text { hidróxidos de ferro e sulfatos; hidróxidos de } \\
\text { cobre e carbonatos; gipsita }\end{array}$ \\
\hline calcopirita & $\mathrm{Cu}_{2} \mathrm{~S}$ & $\mathrm{Cu}^{2+} ; \mathrm{SO}_{4}{ }^{2-} ; \mathrm{H}^{+}$ & hidróxidos de cobre e carbonatos; gipsita \\
\hline bornita & $\mathrm{Cu}_{5} \mathrm{FeS}_{4}$ & $\mathrm{Cu}^{2+} ; \mathrm{Fe}^{3+} ; \mathrm{SO}_{4}{ }^{2-} ; \mathrm{H}^{+}$ & $\begin{array}{l}\text { hidróxidos de ferro e sulfatos; hidróxidos de } \\
\text { cobre e carbonatos; gipsita }\end{array}$ \\
\hline esfarelita & ZnS & $\mathrm{Zn}^{2+} ; \mathrm{SO}_{4}{ }^{2-} ; \mathrm{H}^{+}$ & hidróxido de zinco e carbonatos; gipsita \\
\hline galena & $\mathrm{PbS}$ & $\mathrm{Pb}^{2+} ; \mathrm{SO}_{4}^{2-} ; \mathrm{H}^{+}$ & $\begin{array}{l}\text { hidróxidos de chumbo carbonatos e sulfatos; } \\
\text { gipsita }\end{array}$ \\
\hline
\end{tabular}

$\left({ }^{*}\right) \mathrm{x}=0$ a 0,2

Relevância especial também é apresentada pelas variações de salinidade, resultantes dos processos de mistura da água do mar e dos rios que, por sua vez, traduzem alterações profundas na composição química do meio líquido.

As alterações de força iônica estão na base de um conjunto extenso de fenômenos típicos de estuários: são colóides que floculam e se depositam; complexos que se destroem e dão origem a outros complexos ou precipitados ou 
ainda que libertam elementos que podem estar fixados pela biota ou nas superfícies.

Atuam também nos gradientes de concentração que se criam na água intersticial dos sedimentos dando origem a trocas de massa na interface fundocoluna líquida; trocas iônicas que ocorrem na superfície das partículas, ocupando ou libertando centros ativos dos quais se libertam ou aos quais se ligam elementos essenciais; são moléculas orgânicas complexas, que floculam e, finalmente, se depositam, enriquecendo os sedimentos na sua facção volátil e conferindo-lhes condições favoráveis ao aumento da mobilidade de certos componentes como os íons metálicos etc.

Não é possível generalizar o que ocorre nestes ambientes, uma vez que são sistemas extremamente dinâmicos que se movem constantemente, em resposta aos ventos, marés e ao escoamento dos rios. A compreensão do transporte e destino dos poluentes nestes sistemas, requer conhecimento dos processos físicos, químicos e biológicos que ocorrem, além das propriedades dos próprios contaminantes (Fernandes, 2001).

Os manguezais, por muito tempo e em muitos países têm sido utilizados como uma alternativa de baixo custo para descarte e tratamento de resíduos industriais e domésticos, devido sua capacidade de reter metais pesados e de reaproveitar nutrientes destes resíduos (Ye et al., 2001).

Nas áreas estuarinas da Baixada Santista ocorrem manguezais estabelecidos sobre um solo barro arenoso, onde seu avanço vai no sentido corrente da maré vazante, funcionando como fixadores de sedimentos e como filtro biológico sendo assim considerados como o primeiro elo de um riquíssimo ecossistema marinho (Jurnaux, 1985).

Esta afirmação vem corroborar com o interesse no estudo na região de manguezal de Cubatão, uma vez que as emissões antropogênicas de resíduos contendo metais pesados foram detectadas no local em tempos pretéritos. 


\subsection{GeOQuímicA E Comportamento dos íONS METÁLICOS DE INTERESSE}

Baseando em estudos prévios desenvolvidos pela CETESB (2001), selecionaram-se para estudos os íons ferro, manganês, cobre, chumbo e zinco, cujas concentrações predominam nos resíduos e efluentes.

\subsubsection{Ferro}

O ferro é o mais importante dos metais sendo, depois do alumínio, o mais abundante. Apesar do grande número de compostos, apresenta-se em grandes concentrações sob a forma de óxidos. Seus principais minérios são magnetita $\left(\mathrm{Fe}_{3} \mathrm{O}_{4}\right)$ e hematita tendo como principais impurezas compostos de enxofre e fósforo.

O minério de ferro é utilizado na produção do aço que é sua liga mais conhecida. As ligas de ferro apresentam grande variedade de propriedades mecânicas que dependem de sua composição e do tratamento aplicado.

O ferro com depósitos de minérios distribuídos por todos os continentes é liberado para o ar, água, sedimento e solo (Alloway, 1995).

O estado de oxidação, assim como a forma físico-química segundo a qual os íons ferro se encontram determinam seu comportamento no meio ambiente e sua disponibilidade na biota (Azevedo \& Chasin, 2003).

$\mathrm{Na}$ água, na forma solúvel pode ocorrer como íons di ou trivalentes, no estado coloidal, complexado etc. Como $\mathrm{Fe}^{2+}$ em águas com pH abaixo de $3 \mathrm{e} e m$ condições de anaerobiose pode ser convertidos a $\mathrm{Fe}^{3+}$ formando hidróxidos insolúveis (Lima \& Pedroso, 2001).

A quantidade de ferro presente em um solo sem interferência antropogênica depende de sua proximidade com rochas naturais e do grau de intemperísmo; podem estar na forma solúvel nas águas intersticiais, adsorvidos aos minerais do solo, precipitado, associado a biomassa e complexado com matéria orgânica (Alloway, 1995). 
É um elemento essencial para toda a biota, uma vez que é o componentechave na manutenção da homeostase celular; esta essencialidade se deve à sua incorporação a grande número de enzimas e proteínas (Azevedo \& Chasin, 2003).

Tanto a deficiência quanto o excesso de ferro são prejudiciais aos organismos; a deficiência, por exemplo, pode levar à disfunção do sistema imunológico com alterações em órgãos linfóides, alterando a resistência do hospedeiro a agentes infecciosos. O excesso afeta particularmente mecanismos imunológicos; uma vez que reage com peróxido produzindo radicais livres (Azevedo \& Chasin, op.cit.).

Estudos desenvolvidos por Nelson et al. (1994), mostraram que dietas com elevadas quantidades de ferro mostraram-se associadas ao risco de câncer de cólon.

A Agência de Proteção Ambiental Americana (EPA, 2004) determina que para solos de áreas industriais o valor máximo permitido de ferro é de $306412,11 \mathrm{mg} \mathrm{kg}^{-1}$ e para águas subterrâneas $10949,8 \mu \mathrm{g} \mathrm{dm}^{-3}$, enquanto os valores de intervenção adotados pela Agencia de Proteção Ambiental do Estado de São Paulo (CETESB, 2005) é de $300 \mu \mathrm{g} \mathrm{dm}{ }^{-3}$ de ferro para águas subterrâneas.

A toxicidade do ferro em resíduos é determinada pela Associação Brasileira de Normas Técnicas -Solubilização de resíduos - estabelecendo valor máximo de $0,3 \mathrm{mg} \mathrm{dm}^{-3}$ de ferro (ABNT, 1987).

O limite máximo de descarga de efluentes contendo íons ferro em corpos d'água superficiais é de $15,0 \mathrm{mg} \mathrm{dm}^{-3}$ (CONAMA, 1986). 


\subsubsection{Manganês}

A aplicação do manganês na indústria siderúrgica é devido, principalmente, às suas características físico-químicas, atuando como agente dessulfurante e desoxidante (Romeiro, 1997).

Segundo Hypolito (1980), o manganês é extremamente sensível às variações de $\mathrm{pH}$ e Eh geralmente ocorrendo no meio natural nos estados de valência +2 (como cátion adsorvido ou em solução), $\mathrm{Mn}^{3+}$ (como trióxido de manganês, bastante reativo) e $\mathrm{Mn}^{4+}$ (como dióxido de manganês insolúvel). Essas três formas encontram-se em equilíbrio dinâmico, em que a ocorrência de $\mathrm{Mn}^{3+} \mathrm{e}$ $\mathrm{Mn}^{4+}$ é favorecida pela elevação do $\mathrm{pH}$ e condições oxidantes e de $\mathrm{Mn}^{2+}$ em meios com pH baixo e condições redutoras (Nascimento et al., 2006).

O conteúdo de manganês em águas é proveniente dos processos de alteração de rochas e seu transporte e degradação na água é controlado pela solubilidade de seus sais e óxidos. Em geral predomina a forma $\mathrm{Mn}^{2+}$ e os principais equilíbrios que controlam a concentração do manganês em água são aqueles provenientes dos compostos $\mathrm{Mn}(\mathrm{OH})_{2}, \mathrm{MnCO}_{3}$ e $\mathrm{MnS}$, que produzem em

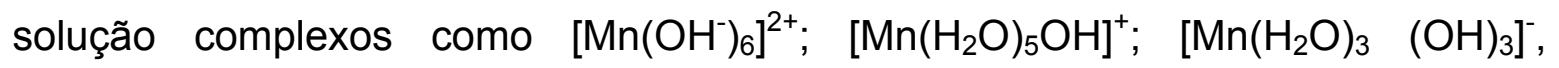
$\left[\mathrm{Mn}\left(\mathrm{H}_{2} \mathrm{O}\right)_{5}\left(\mathrm{HCO}_{3}\right)\right]^{+}$e $\left[\mathrm{Mn}\left(\mathrm{H}_{2} \mathrm{O}\right)_{5}\left(\mathrm{SO}_{4}\right)\right]^{0}$ (Hypolito, 1980; Hypolito, 1993)

Alguns compostos orgânicos como aminoácidos, hidroxiácidos e vários ácidos carboxílicos, podem formar complexos estáveis com $\mathrm{Mn}^{2+}$. Grande número de espécies inorgânicas, como fosfatos, também formam complexos estáveis com esses íons.

Em condições favoráveis, especialmente sob a ação catalítica de microorganismos, a oxidação do $\mathrm{Mn}^{2+}$ é bastante rápida (Hypolito, op. cit..).

Os óxidos e hidróxidos de manganês (III) e (IV) são considerados insolúveis nas condições das águas naturais sendo, no entanto, a estabilidade no estado coloidal dos óxidos favorecida em $\mathrm{pH}$ elevado (Hypolito, op. cit. Nascimento op. cit.). 
As principais formas de ocorrência de manganês no solo são aquelas em que se encontram associados ás estruturas principalmente da pirolusita e/ou óxidos hidratados. Ocorre também como complexos associados à matéria orgânica podendo ser deslocado por ferro, cobre e zinco, os quais possuem constantes de estabilidade maiores.

Os ciclos do manganês no solo envolvem as formas bi e trivalente do metal, havendo equilíbrio dinâmico entre elas. A forma bivalente é transformada por meio da oxidação biológica para a forma trivalente que, posteriormente, pode ser reduzida a $\mathrm{Mn}^{2+}$ em solos muito ácidos; a oxidação bacteriana é considerada baixa, por outro lado, em solos alcalinos, a forma bivalente praticamente desaparece. O potencial de óxido-redução está diretamente relacionado com a atividade dos microorganismos que podem alterar o pH (WHO, 1981; Alloway, 1995; Martins \& Lima, 2001).

O manganês é um elemento essencial ao homem e, sob condições normais contém pequenas quantidades do metal. Estudos sobre sua distribuição no organismo mostram que os locais que apresentam as maiores concentrações são os de maior atividade metabólica como fígado, pâncreas e os relacionados à eliminação, como os rins e os intestinos delgado e grosso. Essa distribuição, provavelmente, correlaciona-se com a quantidade de mitocôndrias do órgão ou tecido, organela onde o manganês se acumula (WHO, op.cit.).

Os alvos primários da ação do manganês no organismo são os pulmões e o sistema nervoso central, embora tenham sido observados efeitos também em outros órgãos. Em trabalhadores expostos ao manganês foram reportadas disfunções neurológicas conhecida como "loucura mangânica"- a caracterização pisiquiátrica dessa síndrome inclui apatia, sonolência, confusão, comportamento bizarro, alucinações visuais, perda de memória, ansiedade e desenvolvimento de condições clínicas graves semelhantes ao Mal de Parkinson, marcado por tremores e rigidez muscular (Barceloux, 1999). 
Apesar de ser considerado elemento essencial para várias espécies apresenta, paradoxalmente, toxicidade significativa para muitas delas (Azevedo \& Chasin, 2003).

As toxicidades oral e dérmica do manganês normalmente são reduzidas; estudos em animais, no entanto, sugerem que o elevado consumo pode produzir efeitos nocivos ao desenvolvimento, aos processos reprodutivos, danos degenerativos e impotência; as fêmeas parecem menos susceptíveis aos efeitos reprodutivos que os machos (WHO,1981).

Informações sobre o potencial de carcinogenicidade do manganês são limitadas. Estudos realizados com ratos machos expostos a doses acima de 331 $\mathrm{mg} \mathrm{kg}^{-1}$ de peso dia, durante dois anos, apresentaram aumento de incidência de adenoma nas células pancreáticas, no entanto pela Agência Internacional de Investigação para o Câncer (IARC) o manganês não é incluído como carcinógeno humano (Barceloux, 1999).

A Agência de Proteção Ambiental Americana (EPA, 2004) determina que para solos de áreas industriais o valor máximo permitido de manganês é de 19458,11 $\mathrm{mg} \mathrm{kg}^{-1}$; para águas subterrâneas $875,99 \mu \mathrm{g} \mathrm{dm}^{-3}$ - enquanto os valores de intervenção adotados pela Agencia de Proteção Ambiental do Estado de São Paulo (CETESB, 2005) é de $400 \mu \mathrm{g} \mathrm{dm}^{-3}$.

A toxicidade do manganês em resíduos determinada pela Associação Brasileira de Normas Técnicas - Solubilização de resíduos estabelece valor máximo de $0,1 \mathrm{mg} \mathrm{dm}^{-3}$ de manganês, o limite máximo de descarga de efluentes em corpos d'água superficiais é de $1,0 \mathrm{mg} \mathrm{dm}^{-3}$ (CONAMA, 1986).

Estudos realizados pela CETESB (2001), em sedimentos do manguezal de Cubatão, próximo à área de estudos deste trabalho foram detectadas concentrações de 599 a $1561 \mu \mathrm{g} \mathrm{g}^{-1}$. 


\subsubsection{Chumbo}

Em processos siderúrgicos, o chumbo é utilizado como inibidor de corrosão do aço.

Nos solos, ocorre principalmente no estado de oxidação +2, apresenta grande afinidade pelo enxofre ocorrendo sob a forma de sulfetos, sulfatos e grupos sulfidrilas, se presentes em húmus, podem formar íons complexos com o cátion chumbo (McBride, 1994).

Em pH relativamente elevado pode ocorrer complexação do chumbo (II) com matéria orgânica, fenômenos de quimiosorção com óxidos e argilominerais e mesmo precipitação com carbonato, hidróxido ou fosfatos. Em meio fortemente alcalino, a solubilidade pode aumentar pela formação de Pb-orgânico solúvel e hidróxi-complexo (Alloway, 1995; Mcbride, op.cit.).

O chumbo, nos sistemas aquáticos, pode apresentar-se sob diversas formas dependendo do $\mathrm{pH}$ e Eh do meio; pode-se citar, por exemplo, que: o $\mathrm{PbO}_{2}$ é estável em condições de elevado potencial de oxidação em quaisquer faixas de $\mathrm{pH}$; os compostos $\mathrm{PbSO}_{4}, \mathrm{PbSO}_{3}$ e $\mathrm{Pb}(\mathrm{OH})_{2}$ são encontradas em condições de potencial de oxidação baixas e faixas de $\mathrm{pH}$ até 6 , de 6 a 10 e de 10 a 14 respectivamente; o $\mathrm{PbS}$ na interface entre os ambientes oxidantes e redutores e $\mathrm{pH}$ variável; e o $\mathrm{Pb}^{2+}$ em ambiente redutor e $\mathrm{pH}$ variável (Smith et al., 1995).

O transporte do chumbo nas águas superficiais é baixo e sua concentração depende do $\mathrm{pH}$ e teor total de sais dissolvidos, no entanto, é carreado pelos rios, principalmente sob a forma de colóides e/ou ligado a particulados (Smith et al., op.cit.).

Os efeitos do chumbo na saúde humana dependem da intensidade e duração da exposição que pode resultar em uma série de efeitos, desde subcelulares a mau funcionamento do corpo, de inibição de enzimas a mudanças fisiológicas e à morte. As crianças são mais sensíveis que os adultos. $\mathrm{O}$ adulto absorve aproximadamente $10 \%$ do chumbo que passa pelo trato digestivo, enquanto crianças absorvem $50 \%$, sendo a maior parte retida e acumulada no esqueleto, apresentando meia-vida de 20 anos (WHO, 1995). 
Em geral, produtos alimentícios vegetais contêm mais chumbo do que produtos de origem animal. Em vegetais o chumbo é mais elevado nas raízes com exceção de vegetais folhosos que retém poeira, enquanto alimentos de origem animal, como carne, leite e ovos apresentam baixa concentração (Anjos, 2003).

Quaisquer que sejam as vias de absorção, o chumbo tem como destino final o fígado; parte é excretada através da bile, parte é armazenada e uma terceira fração entra na circulação na forma de fosfato de chumbo depositando nos ossos (95\%), fígado, rins, baço, gengiva, cérebro, músculos etc. (Santos et al., 1992).

É um metal que tem efeito cumulativo no organismo, provocando doença crônica (saturnismo), cujos efeitos tóxicos podem ser exemplificados como hematológicos, neurológicos, encefalopatia com sintomas de coma e convulsões, efeitos sobre o sistema nervoso central, psicológicos, renais, mutagenecidade e reprodução (Paoliello et al., 2001).

Nos processos de descalcificação ou sob a ação de medicamentos, o chumbo ósseo pode ser mobilizado, ocasionando episódios agudos de intoxicação. (Santos et al., op.cit.).

A possibilidade de causar câncer em seres humanos não é bem conhecida, entretanto, pesquisas têm revelado que roedores, quando expostos a altas doses do metal, desenvolvem tumores. O Departamento de Saúde e Serviços Humanos dos Estados Unidos tem constatado a possibilidade dos acetatos e fosfatos de chumbo serem carcinogênicos (EPA, 1999).

A Agência de Proteção Ambiental do Estado de São Paulo (CETESB, 2005) determina que o teor máximo permitido de chumbo em solos industriais é de $900 \mathrm{mg} \mathrm{kg}^{-1}$ e $10 \mu \mathrm{g} \mathrm{dm}^{-3}$ para as águas subterrâneas.

A toxicidade do chumbo em resíduos é determinada pela Associação Brasileira de Normas Técnicas, ABNT 10005 - Lixiviação de Resíduos e 10006 Solubilização de Resíduos, com valores de $5,0 \mathrm{mg} \mathrm{dm}^{-3}$ e $0,05 \mathrm{mg} \mathrm{dm}^{-3}$, respectivamente. O limite máximo de descarga de efluentes contendo íons chumbo em corpos d'água superficiais é de $0,5 \mathrm{mg} \mathrm{dm}^{-3}$ (CONAMA, 1986). 
A legislação ambiental brasileira não dispõe de critérios de qualidade de sedimento e também não existem dados basais das substâncias químicas em sedimentos da região de estudo. Considerando estes fatos optou-se por utilizar critérios estabelecidos pela agencia ambiental canadense, que apresenta dois níveis de classificação: Thresold Effect Level (TEL) - concentração abaixo da qual não são esperados efeitos adversos sobre organismos aquáticos e Probable Effect Level (PEL) - concentração acima da qual são esperados efeitos adversos severos sobre organismos aquáticos (EC, 1999).

Estudos realizados pela CETESB (2001), em sedimentos do manguezal de Cubatão, próximo à área de estudos, foram detectadas concentrações de até 567 $\mu \mathrm{g}^{-1}$ de chumbo, sendo os padrões estabelecidos de TEL e PEL 30,2 e $112 \mu \mathrm{g} \cdot \mathrm{g}^{-1}$, respectivamente.

\subsubsection{Cobre}

É utilizado na fabricação do aço patinável que possui teor de cobre superior ao aço carbono comum, apresentando maior resistência à corrosão.

$\mathrm{Na}$ natureza, o cobre apresenta forte tendência a ligar-se quimicamente ao enxofre, formando compostos pouco solúveis como a calcocita $\left(\mathrm{Cu}_{2} \mathrm{~S}\right)$ que é o mais rico dos sulfetos, com $80 \%$ em cobre e a calcopirita $\left(\mathrm{CuFeS}_{2}\right)$ que é o principal minério de cobre (Alloway,1995).

$\mathrm{O}$ fator que controla sua disponibilidade é o $\mathrm{pH}$; em solução com $\mathrm{pH}<6,9$ predomina o $\mathrm{Cu}^{2+}$ (e produtos de sua hidrólise como $[\mathrm{Cu}(\mathrm{OH})]^{+}$e $\left[\mathrm{Cu}_{2}(\mathrm{OH})_{2}\right]^{2+}$ ) enquanto em $\mathrm{pH}>7$, domina $\mathrm{Cu}(\mathrm{OH})_{2}$. Assim, em solos ácidos encontra-se disponível para plantas na forma $\left[\mathrm{Cu}\left(\mathrm{H}_{2} \mathrm{O}\right)\right]^{+2}$ e em solos neutros/alcalinos, como $\mathrm{Cu}(\mathrm{OH})_{2}$ (Alloway, op. cit.).

A forma mais comum em solução é a complexada com substâncias orgânicas solúveis. Estima-se que $80 \%$ das formas solúveis do cobre sejam quelatos orgânicos. Dada a grande afinidade com constituintes orgânicos do solo a complexação orgânica pode influir na biodisponibilidade e migração do cobre no 
solo, inclusive nas reações com componentes inorgânicos (Kabata-Pendias \& Pendias, 1992).

Para elementos essenciais como o cobre, há riscos associados ao ingresso corpóreo tanto de baixas como de elevadas concentrações do metal. A essencialidade desse metal deve-se a sua incorporação a grande número de enzimas e proteínas estruturais como tirosinase, responsável pela pigmentação da pele (Merian, 1991; Mattiazzo-Prezotto, 1994).

Poucos são os casos reportados sobre efeitos agudos do cobre, entre eles destacam-se a queimação gástrica, náuseas, vômitos, diarréias, lesões no trato gastrointestinal e anemia hemolítica. O efeito crônico é raramente reportado, podendo-se citar o "Mal de Wilson", doença congênita que provoca acúmulo de cobre no fígado, rim e cérebro resultando em anemia, anormalidades neurológicas e córnea opaca (Barceloux, 1999).

A Agência de Proteção Ambiental Americana (EPA, 2004) determina que os teores máximos permitidos de cobre em solos industriais seja de 40876,66 $\mathrm{mg} \mathrm{kg}^{-1}$ e 1459,99 $\mu \mathrm{g} \mathrm{dm}^{-3}$ para as águas subterrâneas; enquanto os valores de intervenção adotados no Estado de São Paulo pela Agência de Proteção Ambiental do Estado de São Paulo (CETESB, 2005) para áreas industriais é de $600 \mathrm{mg} \mathrm{kg}^{-1}$ de cobre para solos e $2000 \mu \mathrm{g} \mathrm{dm}^{-3}$ para águas subterrâneas.

A toxicidade do cobre em resíduos é determinada pela norma Associação Brasileira de Normas Técnicas- Solubilização de Resíduos, com valor máximo de $1,0 \mathrm{mg} \mathrm{dm}^{-3}$. O limite máximo de descarga de efluentes contendo íons cobre em corpos d'água superficiais é de $1,0 \mathrm{mg} \mathrm{dm}^{-3}$ (CONAMA, 1986).

Estudos realizados pela CETESB (2001) em sedimentos do mangue de Cubatão próximo à área de estudos foram detectadas concentrações de cobre que variaram de 0,41 a $100 \mu \mathrm{g} \mathrm{g}^{-1}$, sendo os padrões estabelecidos de TEL e PEL 18,7 e $108 \mu \mathrm{g} \mathrm{g}^{-1}$, respectivamente (EC, 1999). 


\subsubsection{Zinco}

A principal aplicação do zinco em usinas siderúrgicas, é na galvanização do aço ou ferro, para protegê-los da corrosão com cerca de $50 \%$ do consumo.

É um elemento essencial à vida das plantas e animais, ocorre na forma livre e combinado como $\mathrm{ZnS}$ (Blenda), $\mathrm{ZnCO}_{3}$ (Smithsonita), $\mathrm{ZnO}$ (Zincita) e Calamina $\left(\mathrm{Zn}_{4}\left(\mathrm{SiO}_{7}\right)(\mathrm{OH})_{2} \cdot \mathrm{H}_{2} \mathrm{O}\right.$, sendo a principal ocorrência de zinco proveniente da mineralização de sulfeto de zinco ( $Z n S)$, muitas vezes associado a sulfetos de outros metais, principalmente chumbo, cádmio, cobre e ferro (Anjos, 2003).

Ocorre nas águas superficiais como $\mathrm{Zn}^{2+}$ onde forma aquocomplexo, carbonatos e complexados com orgânicos. A sorção é o destino dominante do zinco em ambientes aquáticos e ocorre por meio de óxidos e hidróxidos de ferro, alumínio e manganês, argilo-minerais e matéria-orgânica. $\mathrm{O}$ zinco é sorvido em pH abaixo de 7 e prontamente transportado em muitas águas superficiais (Smith et al., 1995).

Nos solos e sedimentos em pH 7,7 - o zinco se hidrolisa e é facilmente adsorvido por argilas, carbonatos ou óxidos. Em condições aeróbias é bivalente, predominante em $\mathrm{pH}$ ácido e nas condições anaeróbias sob a forma ZnS (Quináglia, 2001).

Apesar de ser um nutriente essencial, presente em organísmos vivos, estes parecem ser um pequeno reservatório se comparado a solos e sedimentos aquáticos. $\mathrm{O}$ zinco pode se acumular em animais aquáticos e apresentar 50 a 1000 vezes a concentração presente na água; crustáceo e peixes podem acumular zinco tanto da água quanto dos alimentos (Azevedo \& Chasin, 2003).

Em termos de saúde pública, a principal via de exposição humana é a ingestão; a inalação é uma fonte insignificante para a exposição não ocupacional. A ingestão de altas concentrações de zinco acima dos valores máximos permitidos recomendados na dieta ( $15 \mathrm{mg} \mathrm{dm}^{-3} /$ dia para o homem e $12 \mathrm{mg} \mathrm{dm}^{-3} /$ dia mulher) pode causar anemia danos pancreáticos, diminuição do HDL-colesterol no sangue, falhas no crescimento e retardo na maturidade sexual (Barceloux, 1999). 
A Agência de Proteção Ambiental Americana (EPA, 2004) determina que os teores máximos permitidos de zinco em solos industriais é de $306412,11 \mathrm{mg} \mathrm{kg}^{-1} \mathrm{e}$ $10949,88 \mu \mathrm{g} \mathrm{dm}{ }^{-3}$ para as águas subterrâneas; enquanto os valores de intervenção adotados no Estado de São Paulo pela Agência de Proteção Ambiental do Estado de São Paulo (CETESB, 2005) para áreas industriais é de $2000 \mathrm{mg} \mathrm{Kg}^{-1}$ de zinco para solos e $5000 \mu \mathrm{g} \mathrm{dm}^{-3}$ para águas subterrâneas.

A toxicidade do zinco em resíduos é determinada pela Associação Brasileira de Normas Técnicas - Solubilização de Resíduos, com valor de $5,0 \mathrm{mg} \mathrm{dm}^{-3}$. 0 limite máximo de descarga de efluentes contendo de íons zinco em corpos d'água superficiais é de $5,0 \mathrm{mg} \mathrm{dm}^{-3}$ (CONAMA,1986).

Estudos realizados pela CETESB (2001), em sedimentos do mangue de Cubatão próximo à área de estudos foram detectados concentrações de zinco de até $2600 \mu \mathrm{g} \mathrm{g}^{-1}$, sendo os padrões estabelecidos de TEL e PEL 124 e $271 \mu \mathrm{g} \mathrm{g}^{-1}$, respectivamente $(E C, 1999)$. 


\section{3. ÁREA DE ESTUDOS}

\subsection{LocalizaÇÃo E Acessos}

O Aterro Industrial localiza-se próximo à Rodovia Cubatão-Guarujá, trecho SP 55, km 64 no Município de Cubatão, Estado de São Paulo- Brasil (Figura 3.1-1.).
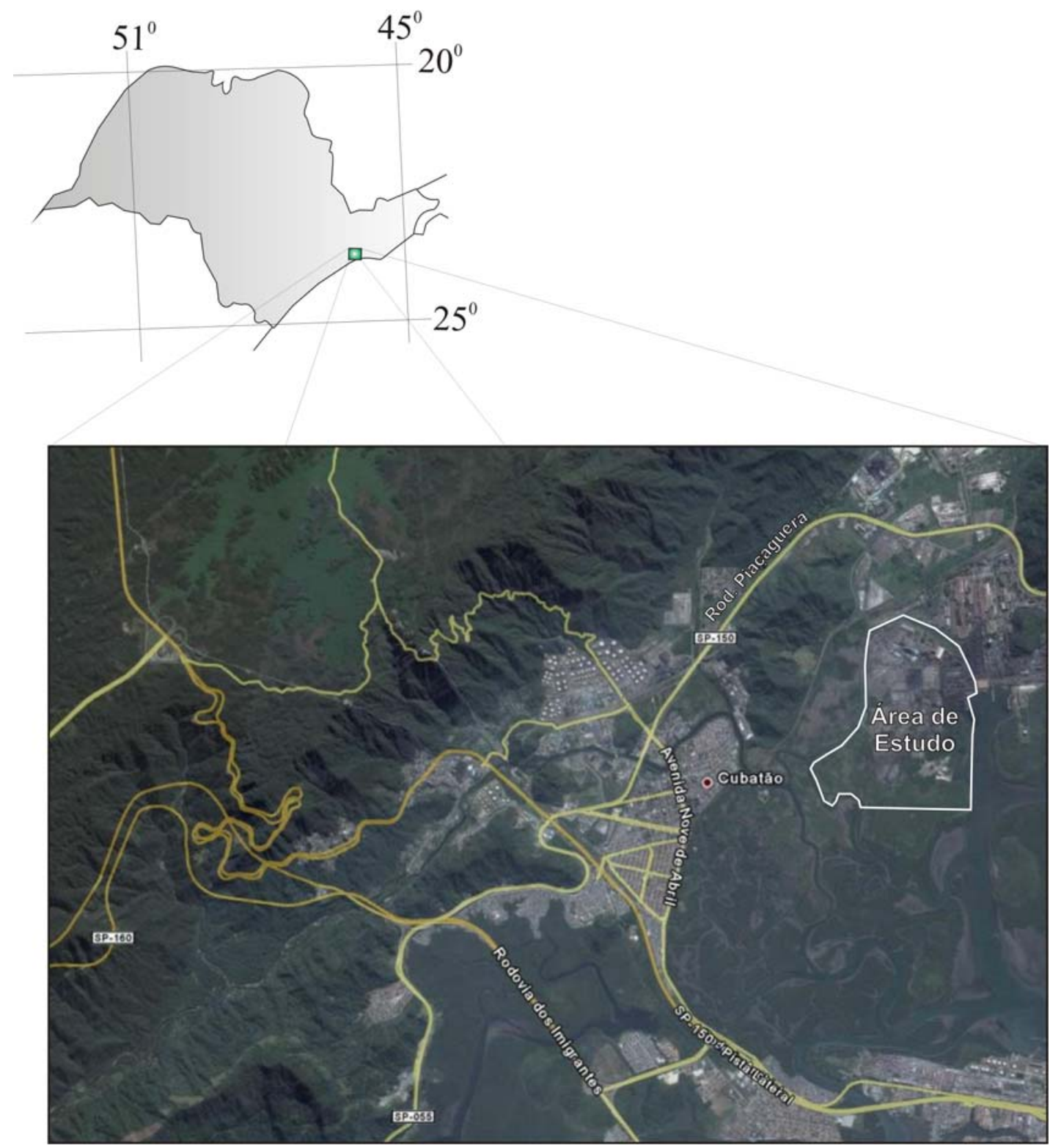

Figura 3.1-1 - Localização da área de estudos no Município de Cubatão - São Paulo. Fonte: Google, 2007. 


\subsection{Geologia}

A área de estudo está localizada sobre terrenos do Holoceno, do Período Quaternário (Figura 3.2.1.). Este período pode ser definido como o intervalo de tempo onde os depósitos são caracterizados bioestratigraficamente através de seu conteúdo faunístico e florístico (Suguio, 1978).

Nos sedimentos ocorrem quartzo, caulinita, gibbsita, além de illita, flogopita, montmonillonita e feldspatos em pontos isolados. Minerais pesados como epidoto, sillimanita, anfibólios e piroxênios ocorrem secundariamente (Ferrer, 2001).

A formação da assembléia de minerais presentes no sedimento provavelmente sofre contribuição dos gnaisses do Complexo Costeiro, muito próximos à área de estudo, que sofreram erosão e aterramento, também fornecendo sedimentos argilosos (Ferrer, op. cit.).

São terrenos arenosos e areno-siltosos com grande quantidade de matéria orgânica proveniente do acúmulo e decomposição vegetal das espécies de mangue.

A maior parte dos depósitos sedimentares da Baixada Santista estão diretamente relacionados com episódios transgressivos, gerando dois tipos de sedimentos. Os primeiros, Plestocênicos, depositados em ambientes mistos continental e marinhos, argilosos ou arenosos em sua base e arenosos no topo. Os outros, Holocênicos, são constituídos de argilas e areias ricas em conchas, foram depositadas em locais de erosão dos sedimentos Plestocênicos, em canais, lagunas, baías ou estuários, denominados genericamente de Sedimentos flúviolagunares e de Baías. Eles se formaram quer pelo retrabalhamento de areias e argilas da Formação Cananéia, quer por sedimentos de águas tranqüilas. Sobre esses terrenos, estão sedimentados os manguezais que podem ser encontrados nas margens e fundos de canais, braços de marés e redes de drenagem, podendo apresentar, por vezes, alternâncias de forma caótica de argilas arenosas e areias argilosas (Massad, 1999). 


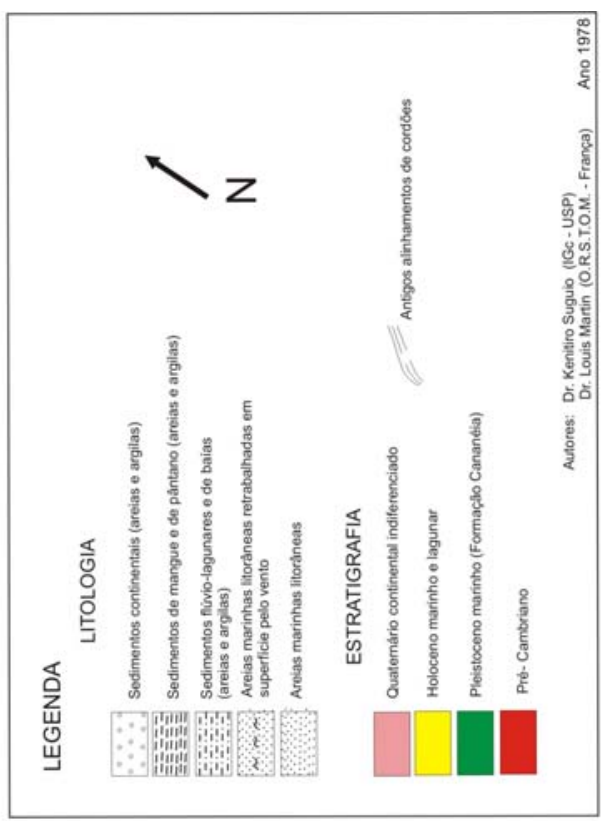

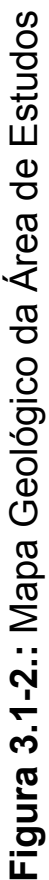

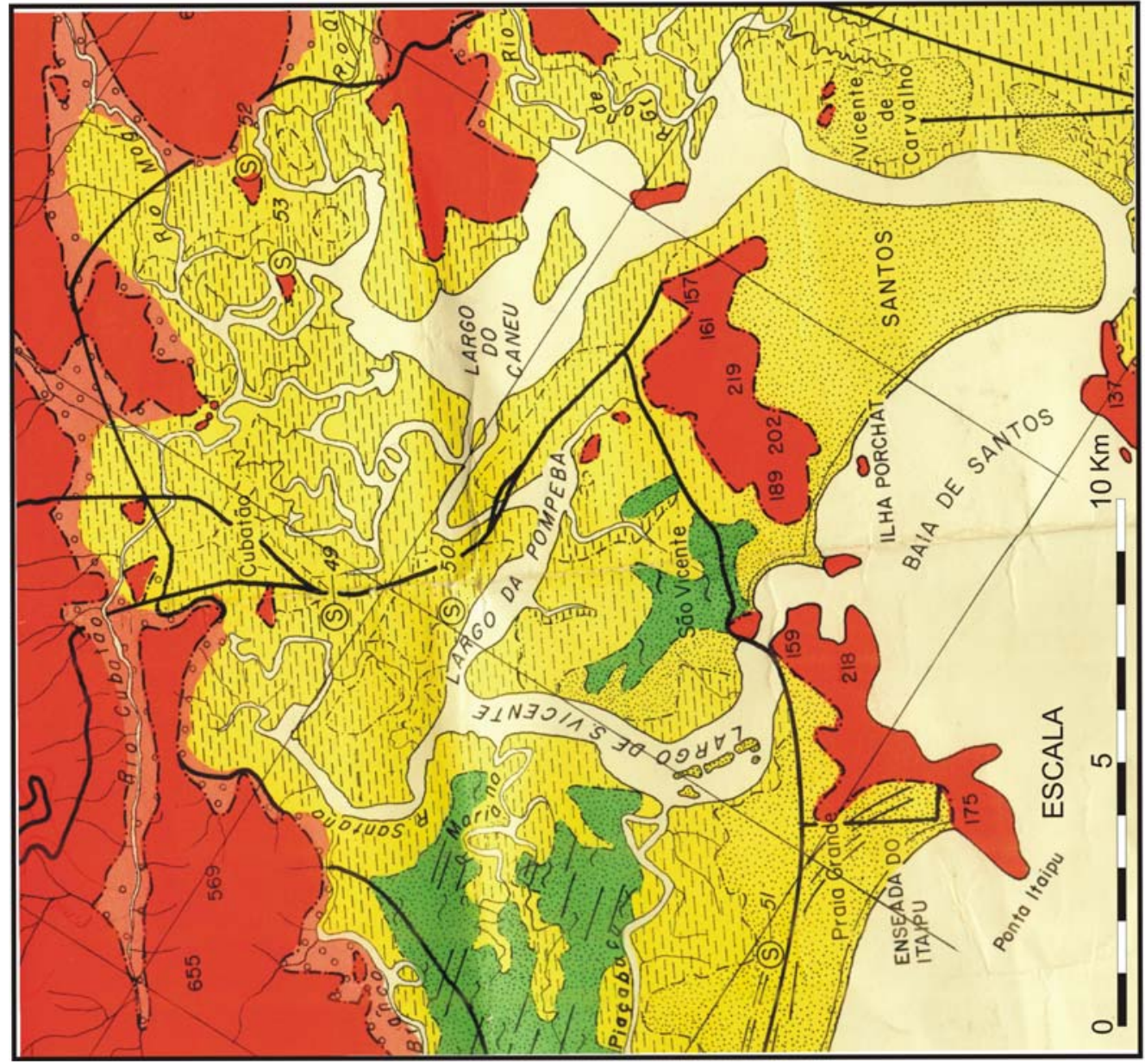




\subsection{HiDROgRAFIA E HidROgEOLOGIA}

Devido à proximidade da Serra do Mar, os rios que banham Cubatão são curtos e torrenciais. Como quase não há declividade na planície sedimentar que separa a Serra do Mar do litoral, o processo de aluvionamento é muito grande. Como conseqüência, tem-se formação de meandros que resultam do duplo trabalho de erosão e acumulação das águas fluviais e de mangues. É difícil distinguir meandros de braços de rios ou de canais marítimos, que se formam dentro dos lagos.

Podem ser definidos dois tipos de rios: os primeiros que têm em comum o fato de suas nascentes serem na Serra do Mar e de possuírem vales que são sulcos importantes a separarem esporões. São rios que nascem torrenciais e se tornam, vencida a escarpa, rios de planície, responsáveis pela grande sedimentação fluvial que dificulta o escoamento das águas, dando então a formação de meandros, furados e dos manguezais. Exemplos desse tipo de rio são o Cubatão e o Mogi. O segundo tipo compreende rios de pequeno curso, praticamente de planície. Exemplos: Rios Casqueiro, Cascalho, Mourão e Onça. Estes rios percorrem trechos montanhosos, recebendo chuvas violentas e, duas vezes por dia (em decorrência da maré), suas partes mais baixas entram em contato direto com água salobra .

A Bacia do Cubatão tem área aproximada de $177 \mathrm{~km}^{2}$. Os rios do extremo Leste são Mogi, Perdido e Piaçaguera e, em seu conjunto, abrangem uma área de bacia da ordem de $52 \mathrm{~km}^{2}$. Os rios são de caráter torrencial, apresentando enchentes de curta duração e pico acentuado.

A rede fluvial nas proximidades da área de estudos engloba o Rio Cubatão, cuja desembocadura no Canal Piaçaguera se dá através de dois braços (ocidental e oriental), o Rio Piaçaguera e o Rio Mogi, que são interligados através de um canal (Figura 3.3.1.). As características destes rios são de interesse das indústrias que ocupam áreas adjacentes e da comunidade que habita no Bairro Vila Parisi (Consultoria Paulista, 2004). 


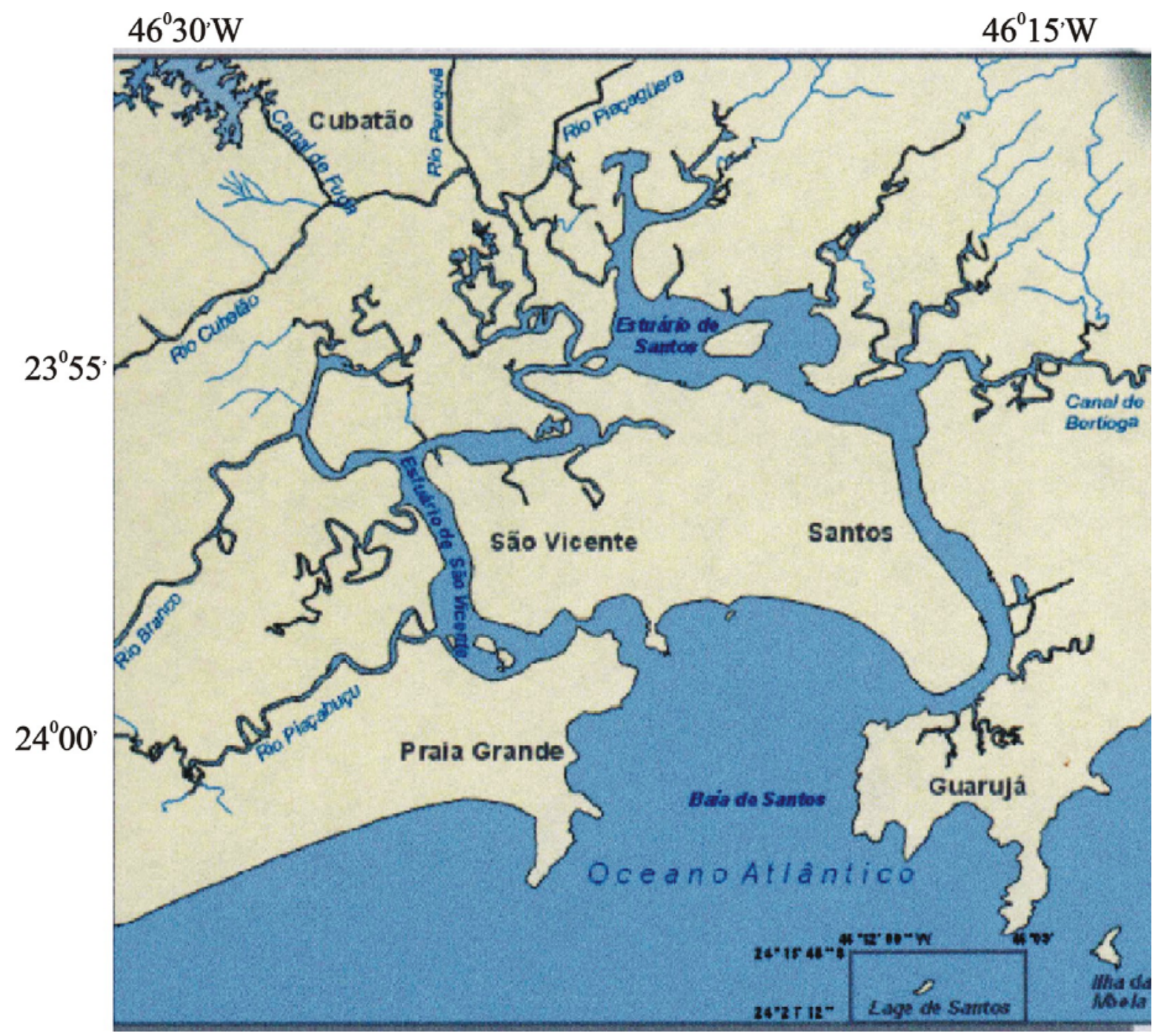

Figura 3.3-1.: Principais Rios da Área de Estudos. Fonte: www.cetesb.sp.gov.br, 2007

A Bacia Hidrográfica da Baixada Santista é classificada pelo Plano Estadual de Recursos Hídricos (PERH), aprovado pela Lei $n^{\circ}$ 9.034/94, como uso industrial, conforme carta do Meio Ambiente e sua Dinâmica (CETESB, 1985). Esse Plano divide o Estado de São Paulo em 22 unidades de Gerenciamento dos Recursos Hídricos (UGRHs), classificando as bacias hidrográficas conforme seu uso, em indústrias, em industrialização, agropecuárias e de conservação.

A Serra do Mar e os Morros Isolados subjacentes podem ser considerados como área de recarga dos aqüíferos e a faixa litorânea que margeia o Oceano 
Atlântico corresponde à sua área de descarga. A intervenção entre as águas dos aqüíferos e o oceano se dá através de processos de natureza advectiva e efusiva, gerando a chamada cunha salina na zona de mistura entre as águas salinas e não salinas.

As bacias dos Rios Cubatão, Mogi, Quilombo, Jurubatuba e Piaçaguera que fluem para o Estuário Santista, abrigam o aqüífero superior-do tipo livre e de meio poroso- no pacote de sedimentos flúvio-lagunares e fluviais constituído por areias, siltes e argilas dispostos em camadas intercaladas. Estas águas, jutamente com as do aqüífero profundo que aflui pelas cabeceiras, escoam, permanentemente em direção ao oceano.

Durante as marés de enchente e passagens de frentes frias, as águas oceânicas penetram no estuário em direção às cabeceiras, gerando estratificação pelas diferenças de densidade criando circulação longitudinal. A água doce, concentrada em uma camada superior, move-se a jusante com maior transporte residual e a água salgada, constituindo uma camada inferior, movimenta-se a montante.

A avaliação hidrogeológica da área de estudo teve por base estudos desenvolvidos pela Consultoria Paulista (2004), apresentadas a seguir:

As investigações diretas $e$ indiretas de subsuperfície realizadas possibilitaram idealização de um modelo hidrogeológico local. Estas investigações compreenderam:

- sondagens geofísicas pelo método de eletroresistividade, para delimitação da cunha salina;

- poços superficiais para monitoramento da superfície piezométrica, direção e velocidade de fluxo subterrâneo e obtenção da condutividade hidráulica;

- poços multiníveis profundos - verificação da existência de componentes verticais no fluxo subterrâneo e caracterização das zonas de recarga;

- ensaio de bombeamento e recuperação por meio de poço - obtenção dos parâmetros hidrodinâmicos do aqüífero; 
- ensaios slug test - para determinação da condutividade hidráulica do substrato;

- ensaios de aqüífero - monitoramento do comportamento do nível d'água do poço;

- sondagens à percussão, com medida da profundidade da superficie freática, ao longo das margens do Canal Piaçaguera.

As investigações realizadas na área confirmaram existência de duas unidades hidrogeológicas representadas por um aqüífero superior e outro inferior, identificáveis nas sondagens por eletroresistividade.

No canal, o aqüífero superior abrange sedimentos arenosos finos de manguezal, e argilas marinhas da planície flúvio-lagunar, caracterizado por águas de elevada condutividade elétrica, por conter sais dissolvidos e ser de natureza salobra. A unidade inferior corresponde à camada flúvio-lagunar e flúvio-marinha constituída por areias finas, e a camada de pedregulhos dos sedimentos fluviais presentes na base do pacote sedimentar. Esta unidade possui baixa condutividade elétrica (alta resistividade), indicando presença de água doce.

A área estudada apresenta vegetação de mangue e sofre influência das oscilações das marés com dinâmica fluvial do tipo drenante. A presença de águas com naturezas químicas diversas, associadas aos processos de eflúvio (escoamento, fluxo por onde as águas vazam) e deflúvio (descarga fluvial) que caracterizam a região, imprimem caráter salobro às águas superficiais livres e à parte superior das águas subterrâneas.

\subsubsection{Aqüífero Superior}

É um aqüífero livre, de meio poroso, que ocupa o pacote sedimentar composto por uma camada superficial de areia fina, pouco argilosa, de sedimentos de mangue, sobre sedimentos flúvio-lagunares representados por argilas com eventuais intercalações arenosas e sedimentos marinhos. 
Através das sondagens executadas, observou-se que a superfície livre deste aqüífero se apresenta sub-aflorante e desenvolve-se até cerca de 25 a $30 \mathrm{~m}$ de profundidade, quando se inicia o aqüífero inferior.

Apresenta baixa capacidade de explotação, evidenciada por baixos valores de vazão, de condutividade hidráulica e de transmissividade, característico de materiais argilosos. Com uma porosidade efetiva média estimada de $20 \%$, obtida experimentalmente para sedimentos silto-argilosos, estimou-se uma velocidade de fluxo em torno de 12 m/ano para as águas subterrâneas.

O regime de fluxo se dá localmente pela infiltração das águas das chuvas e das marés de cheias sobre a planície de maré que se estende ao longo das margens do Canal Piaçaguera. Essas águas se infiltram ao longo dos sedimentos de manguezais e se deslocam pelo meio poroso, perdendo carga hidráulica no sentido da zona de descarga representada pelo canal principal e braços de mar.

A recarga deste aqüífero se dá de forma principalmente difusa, pela infiltração das águas salinas durante a fase de maré cheia o que imprime às suas águas, elevados teores de cloretos. A direção de fluxo acompanha a topografia local.

A ocorrência de áreas mais elevadas na planície de maré e de sedimentos flúvio-lagunares a montante, pode determinar ainda, regime de fluxo mais profundo, alimentado pelas infiltrações decorrentes de precipitações pluviométricas livres da influência das marés. Este fluxo apresentaria uma componente vertical e ascendente nas zonas de descarga e estaria instalado nas camadas mais profundas do aqüífero superior, possuindo caráter mais regional.

\subsubsection{Aqüífero Inferior}

Trata-se de um aqüífero confinado, instalado a partir de 25 a $30 \mathrm{~m}$ de profundidade até o limite do embasamento cristalino. Suas águas se inserem no contexto de fluxo subterrâneo da Baixada Santista, cuja zona de recarga é a Serra do Mar e a descarga se dá na área costeira. 
O fluxo das águas é regional e ascendente, determinado pela recarga proveniente da Serra do Mar, Serra do Quilombo, Serra do Mourão e Morros Isolados, com altas cargas hidráulicas. Por essa razão, são reduzidas as possibilidades de contaminação dessas águas.

As características de elevada condutividade hidráulica, determinada pela natureza granular dos materiais, as boas condições de recarga e a alta transmissividade esperada emprestam, a este aqüífero, possibilidades de explotação.

\subsection{3. Área do Aterro}

Os poços de monitoramento instalados permitiram o conhecimento da topografia da superfície freática ou topo do aqüífero livre e a partir da geometria das curvas de isoprofundidade, a identificação das direções de fluxo da água subterrânea.

As variações potenciométricas observadas indicam que o fluxo subterrâneo se dá de forma radial, da área central para os corpos d'água do entorno, representados pelo Canal Piaçaguera e Rio Cubatão. A região apresenta drenagem superficial difusa, condicionada pela disposição de sedimentos realizada no passado.

Também se constatou influência das oscilações das marés no comportamento do lençol freático.

Quanto à penetração da cunha salina na área, registrou-se um vetor de direção sudoeste-noroeste, o qual pode estar condicionado pela presença de estruturas geológicas do maciço rochoso sob o pacote sedimentar, ou barreiras de permeabilidade no próprio pacote. 


\subsection{Vegetação Geomorfologia e Clima}

\subsubsection{Vegetação}

Segundo Gutberlet (1996), no Município de Cubatão podem ser encontrados três tipos de vegetação:

a) vegetação dos brejos de água doce - típico de regiões invadidas pelas águas dos rios e dos riachos na época das chuvas. Encontram-se ervas de várias qualidades, gramíneas formando prados e florestas baixas, onde aparecem ipê de brejos e outras espécies.

b) vegetação do manguezal - compreende na Região da Baixada Santista uma área de $100 \mathrm{~km}^{2}$, excluindo as zonas devastadas. Poucos são os vegetais que sobrevivem nessas condições ambientais, devido o baixo teor de oxigênio e pouca consistência do solo, aparecem freqüentemente vegetais com raízes muito desenvolvidas. No manguezal, durante a maré alta, vê-se somente as copas das árvores e arbustos. Durante a maré baixa, observam-se emaranhadas das raízes escoras e pneumatóforos. Em Cubatão, as áreas cobertas pelos manguezais foram devastadas, drenadas e usadas para o plantio e construção de casas.

c) vegetação das escarpas da serra e dos morros - corresponde à Mata Tropical, rica em espécies vegetais com predomínio das árvores de grande porte. Destacam-se entre estas a embaúba-preta, araúba, amarelinho, quaresmeira. A quaresmeira é também chamada quaresma, manacá-da-serra e jacatirão. Aparecem também trepadeiras, ervas e epífitas.

Essa vegetação foi muito devastada nos morros para exploração das pedreiras ou substituída pelos bananais e ainda, no passado, para a obtenção de lenha. Nas últimas décadas, a vegetação sofreu muito através das invasões das encostas da Serra do Mar. 


\subsubsection{Geomorfologia}

A área está inserida nas Unidades Morfoestruturais Bacias Cenozóicas, Subunidade Morfoestrutural Planície Litorânea Santista (Ross \& Moroz, 1997).

As Planícies Litorâneas apresentam altimetrias entre 0 e 20 metros e declividades inferiores a $2 \%$. São formadas predominantemente por sedimentos inconsolidados e sedimentos fluviais arenosos/argilosos também inconsolidados, além de cascalhos. Os solos são do tipo Podzol Hidromórfico e Hidromórficos. São áreas que apresentam baixa densidade de drenagem, com padrão meandrante e anastomosado (Ross \& Moroz, op. cit.).

\subsubsection{Clima}

A área de Cubatão, de acordo com a carta do Meio Ambiente da Baixada Santista, sofre efeito massas de ar subtropical, polar e equatorial continental.

A massa equatorial possui ação máxima durante os meses de verão, caracterizando-se por gerar uma situação de instabilidade que leva a quase ausência de inversões térmicas.

As transições entre inverno e verão são extremamente curtas, sem estações de outono e primavera. Já as inversões térmicas do tipo radiação, ocorrem com relativa freqüência.

A circulação dos ventos superficiais durante o dia é preferencialmente SW para NE, favorecendo transporte e acúmulo de poluentes no fundo do vale. À noite, a predominância dos ventos superficiais ocorre na direção NE para SW.

A alta média da umidade relativa do ar ao longo do ano (70\% a $90 \%)$ na Região de Cubatão é desfavorável sob o ponto de vista da poluição atmosférica (CETESB, 1988).

A região possui altos índices pluviométricos, principalmente nos meses de verão, variando de 2000 a 2500 mm (janeiro a março) e baixas precipitações em julho a agosto, não havendo uma real estação seca (CETESB, 1988). 
As chuvas intensas de curta e longa duração, são altamente favoráveis à redução da poluição, provocando deposição de particulados e relativa redução da concentração de gases.

\subsection{Aspectos Sócio-Econômicos}

Segundo Guteberlet (1996), em 1948, a partir da emancipação do Município com o início da primeira grande fase de industrialização e construção da refinaria de petróleo, o quadro populacional modificou-se drasticamente com diminuição da população rural e afluxo crescente de migrantes a procura de trabalho no setor secundário .

O crescimento populacional no Município tem sido contínuo, estimulado, inclusive, pelo afluxo de imigrantes que chegam em busca de trabalho nas empresas locais (IBGE, 2007).

A crescente industrialização e o incremento populacional deu início à urbanização, do ponto de vista da provisão de infra-estrutura urbana, Cubatão é considerada uma cidade desestruturada e caótica devido a falta de planejamento da ocupação do solo principalmente nos bairros periféricos. A restrição pelas extensas áreas de manguezal e da escarpa da Serra do Mar assim como a concorrência com expansão do uso industrial do solo restringiram o assentamento de imigrantes desprovidos de recursos financeiros a poucos terrenos de fácil acesso, na periferia da cidade (Figura 3.5-1). À margem dos aterros de ferrovias e estradas surgiram novos núcleos habitacionais com densidade habitacional extremamente elevada e que não dispõem de infra-estrutura básica suficiente. 


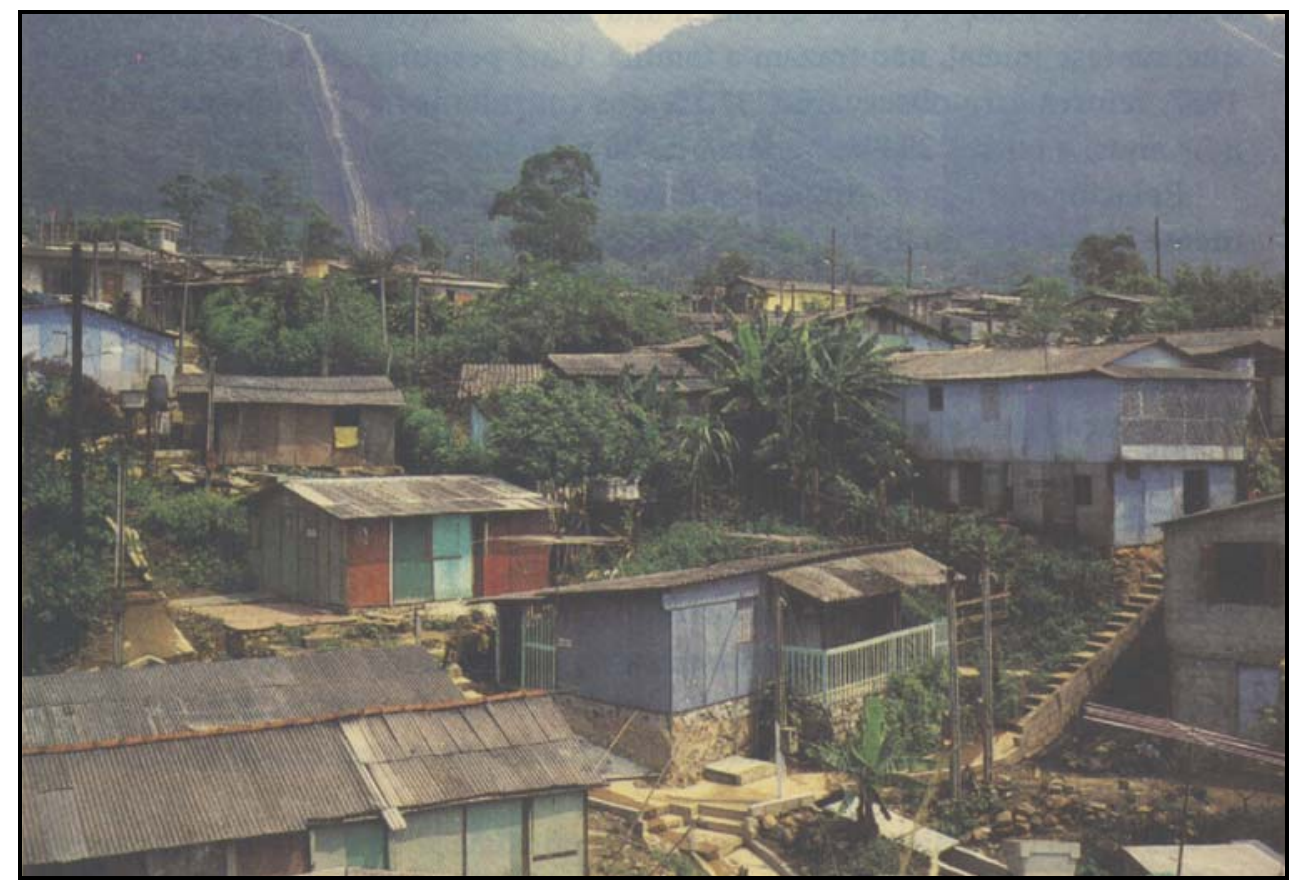

Figura 3.5-1.: Vista parcial do Bairro Vila Parisi, como exemplo da falta de planejamento da ocupação do solo. Fonte: Gutberlet, 1996.

A cidade de Cubatão caracteriza-se por ser um núcleo habitacional principalmente de pessoas carentes, onde os bairros não dispõem de infraestrutura básica suficiente, mostrando as conseqüências de uma produção industrial inadequada à vida humana. 


\section{OBJETIVOS}

Determinar o comportamento hidrogeoquímico de íons de metais pesados em áreas contaminadas pela disposição de resíduos siderúrgicos, utilizando como estudo de caso um Aterro Industrial localizado na llha dos Amores em Cubatão, SP.

Estudar, através de trabalhos experimentais e de campo, mecanismos de fixação e mobilidade de íons poluentes desde a disposição dos rejeitos nos sedimentos de manguezal até sua influência nas águas superficiais, subterrâneas (zonas saturada e não saturada) e em sistemas solos/sedimentos (manguezal). 


\section{AMOSTRAGEM}

A área de estudos localiza-se em manguezal que vem recebendo rejeitos siderúrgicos há mais de trinta anos e, para melhor compreensão das características do material sólido da mistura manguezal/resíduo, neste trabalho, será utilizado o termo solo/sedimento para o material coletado na área do aterro.

É necessário esclarecer que o material disposto na área do Aterro, apesar de servir de substrato para o crescimento de vegetações típicas de manguezal (Figuras 5.1-1 a,b), trata-se de resíduos descartados desde o início das atividades da siderúrgica que foram utilizados para aterrar quase a totalidade da área. Sabese que o mangue apresenta grande capacidade de adaptação a ambientes estressantes e a presença desta vegetação, sob este material é comprovação de sua capacidade adaptativa, sujeita a estudos posteriores. 
a)

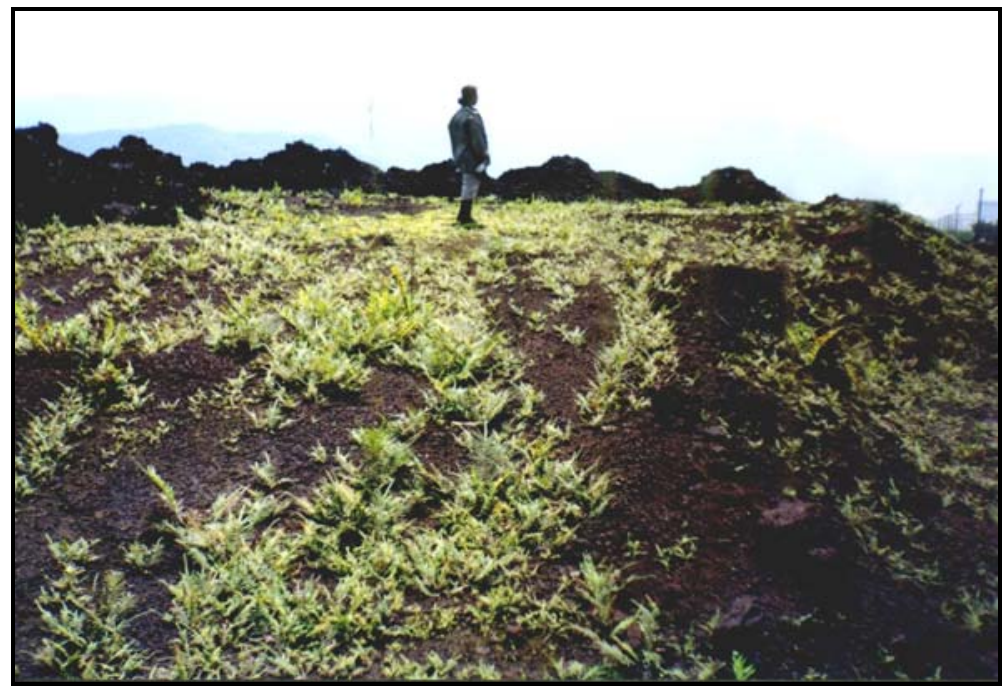

b)

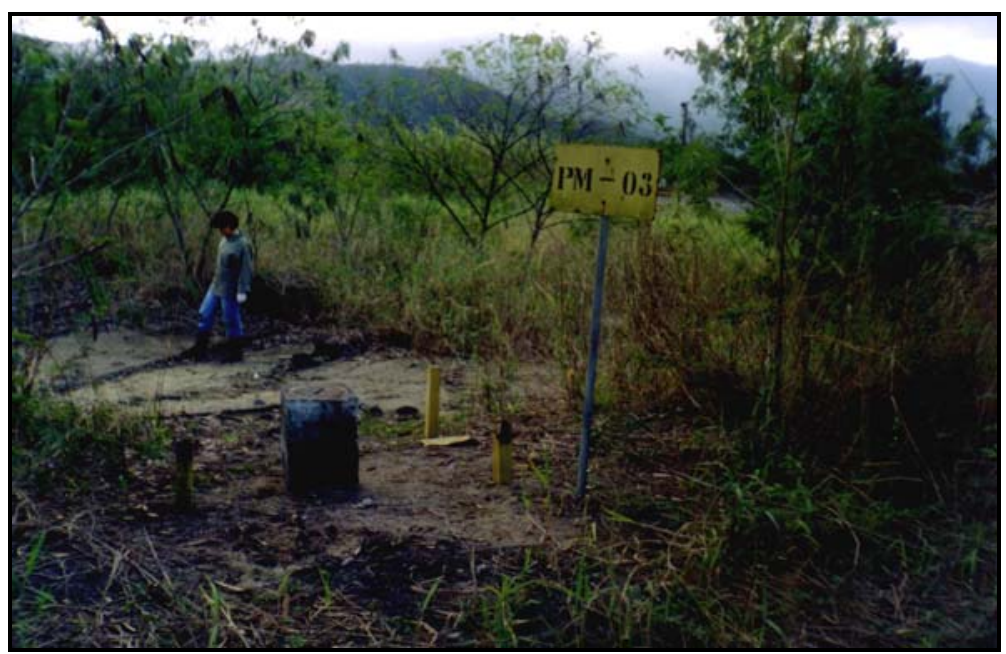

Figura 5.1-1 ( a, b).: Fotos mostrando a adaptabilidade da vegetação junto ao aterro formado pelo descarte de resíduos siderúrgicos.

Para este estudo, foram amostrados matéria prima utilizadas na fabricação do aço, ou seja: minério de ferro (Mi), carvão mineral (CM) e coque (CQ).

Em pontos estrategicamente escolhidos (Figura 5.2.) foram coletadas amostras de águas subterrâneas (PM1, PM2, PM3, PM4 e PM5), superficiais do Rio Piaçaguera (As1 e As2), sedimentos das margens (Sd1 e Sd2), amostras de solos/sedimentos associados aos poços de monitoramento (S1, S2, S3 e S4) e efluentes provenientes do Aterro (EF1 e EF2). 
Foram também coletados materiais (R1) dispostos em diferentes pontos na célula do Aterro. A célula do aterro apresenta na base uma camada de 1 metro de espessura de argila adensada, com grau de permeabilidade de $\mathrm{K}=10^{-7} \mathrm{~cm} \mathrm{~s}^{-1}$, a segunda camada da impermeabilização é uma geomembrana de polietileno de alta densidade $(P E A D)$ de $1,5 \mathrm{~mm}$. Acima dela, cobrindo toda a área há uma geogrelha de plástico para drenagem testemunho que, por sua vez, recebe um novo revestimento com geomembrana de PEAD de $2 \mathrm{~mm}$. Por fim, como última camada, em contato direto com os resíduos, há uma proteção mecânica com pneus preenchidos com material granulado (pedras).

Os efluentes (EF1) gerados na célula do aterro, são drenados e captados através de tubulações, armazenados em um tanque para tratamento.

Em pontos fora da célula, mas também pertencentes ao Aterro, amostraramse materiais depositados em forma pilhas de resíduos (R2 e R3) e escórias (ES). Os materiais percolados na área do Aterro (EF2) são também drenados, captados por tubulações subterrâneas e descartados diretamente na margem direita do Rio Piaçaguera. 


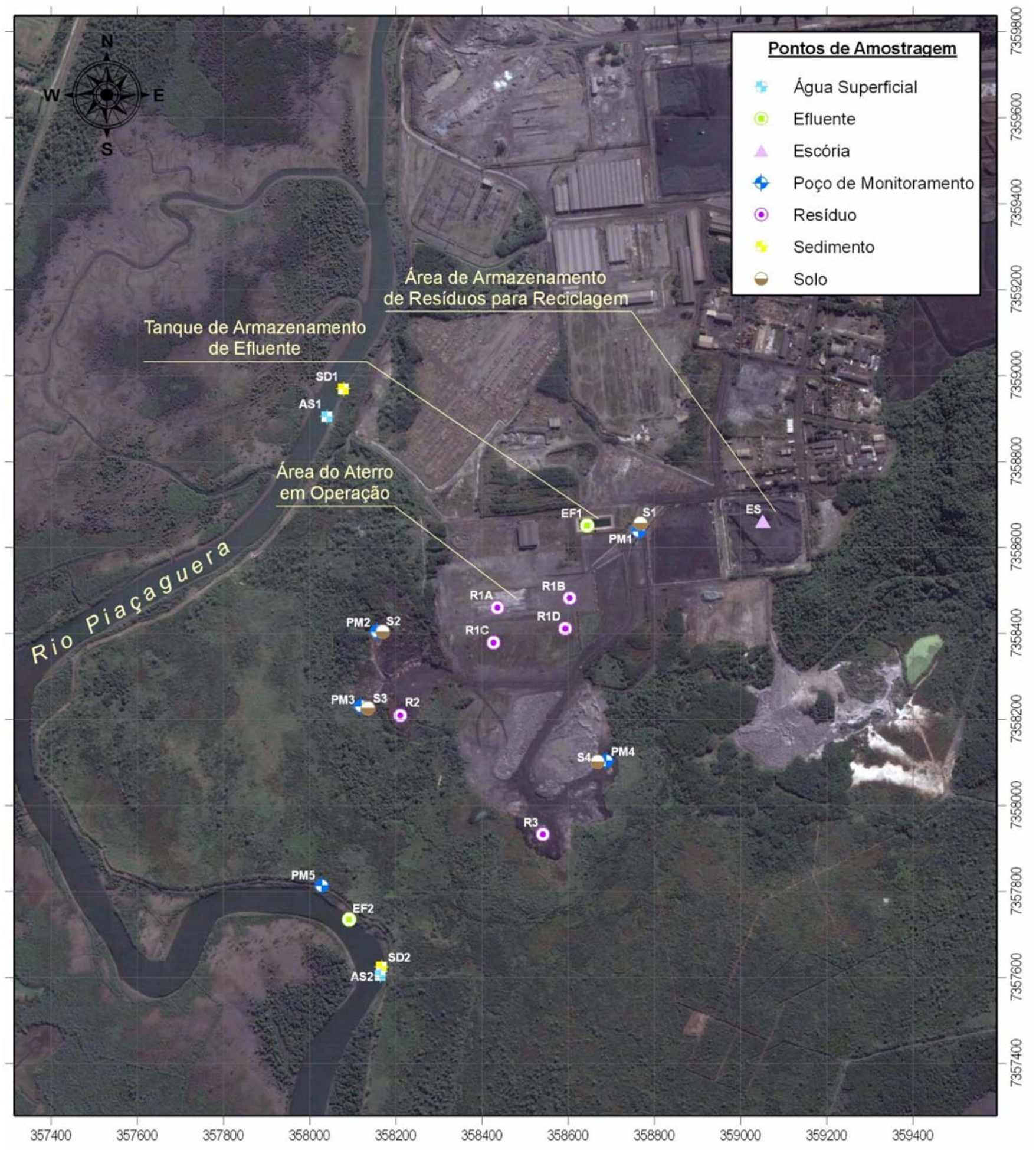

Figura 5.1-2: Localização dos pontos de amostragem no Aterro Industrial. Fonte: Google, 2007 


\subsection{1. Águas Subterrâneas e Superficiais}

Foram coletadas cinco amostras (PM1 A PM5) de águas subterrâneas em poços de monitoramento (Figura 5.1.1-1).

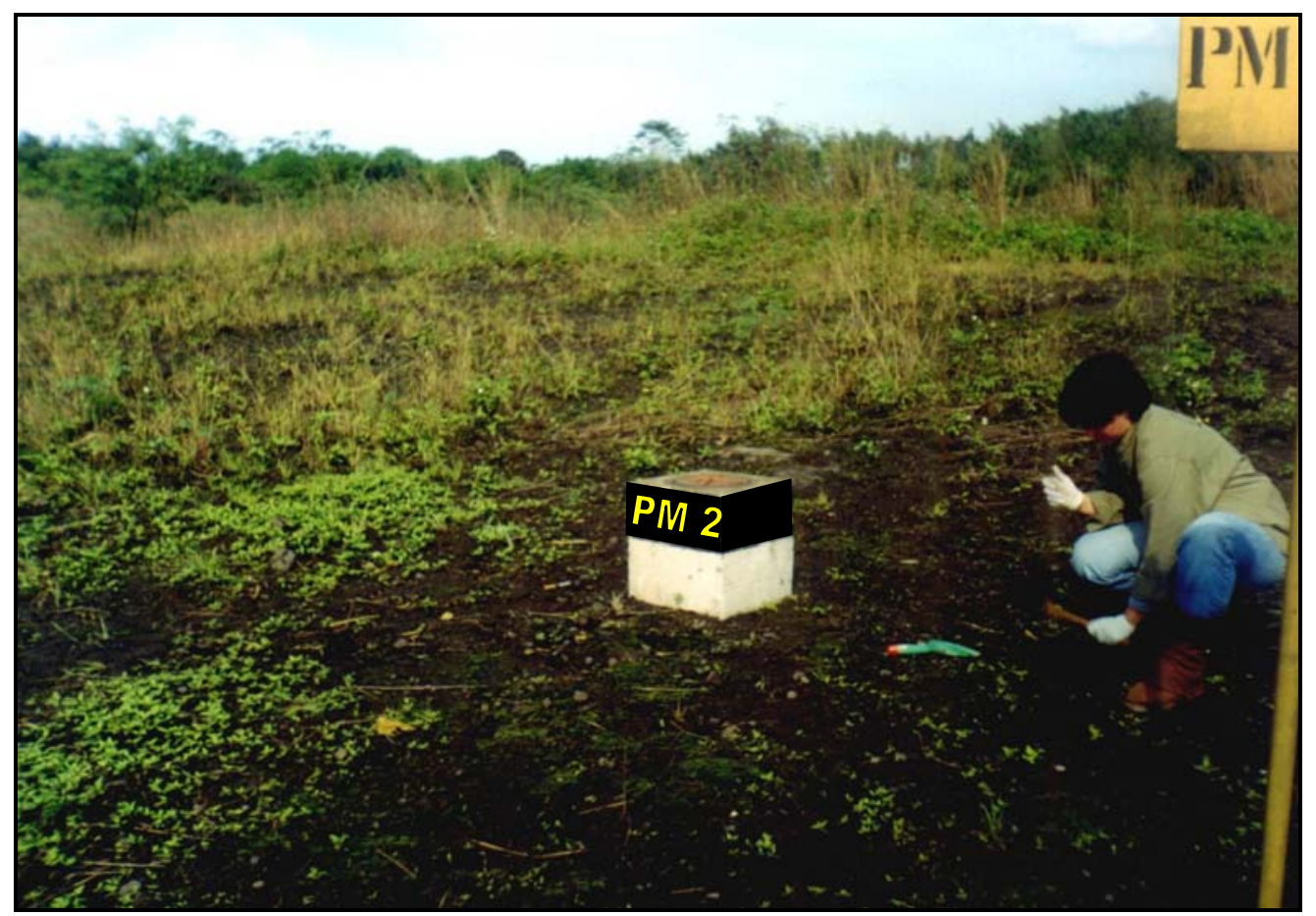

Figura 5.1.1-1: Poço de monitoramento (PM 2) no Aterro Industrial

Procurando selecionar pontos de amostragens representativos, foram efetuadas coletas de águas superficiais do Rio Piaçaguera (Figura 5.1.1-2.) e em dois pontos próximos ao Aterro: a montante (As1) e a jusante (As 2) nos limites do Aterro. 


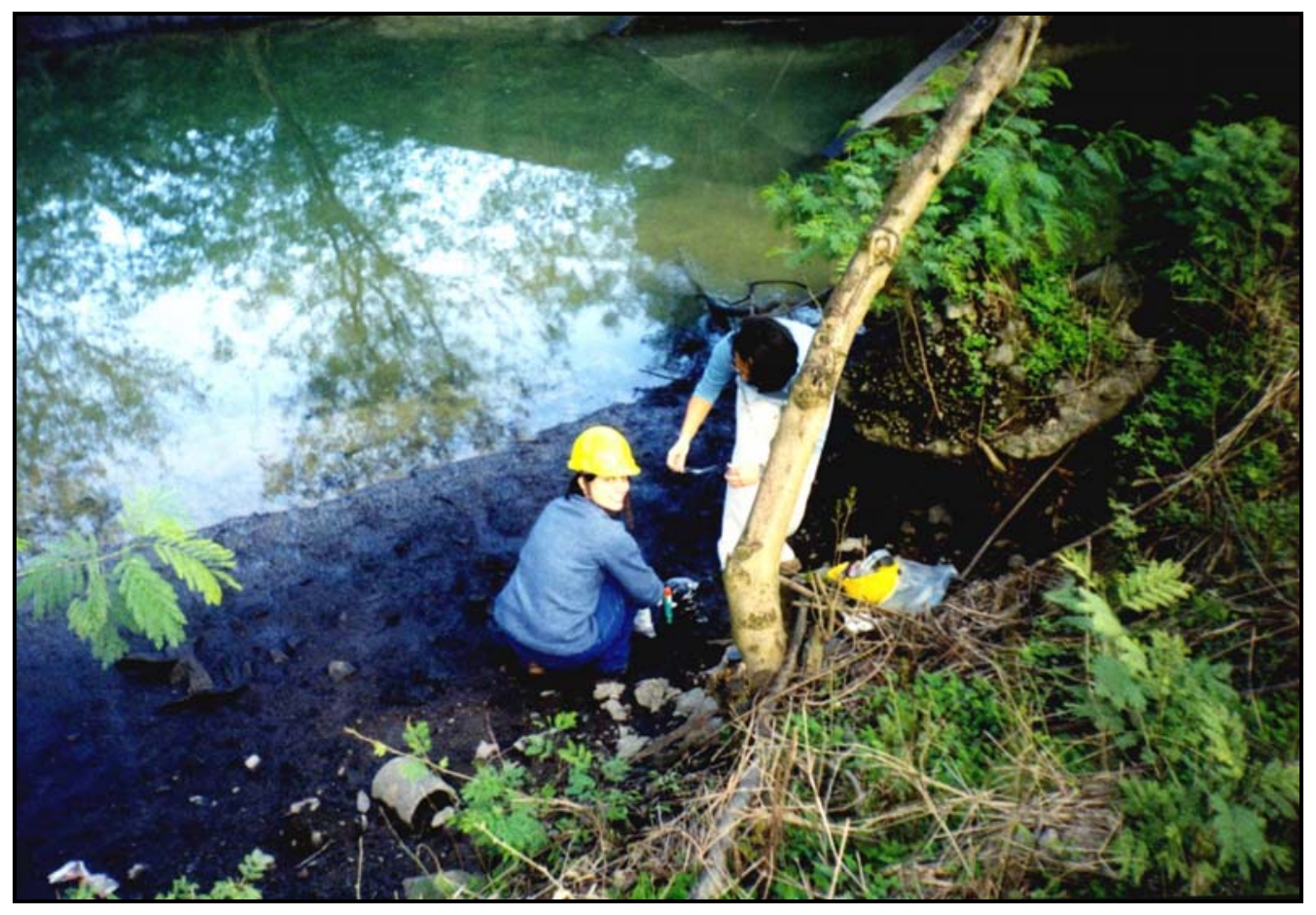

Figura 5.1.1-2.: Coleta de amostra de água superficial e sedimento da margem do Rio Piaçaguera

\subsubsection{Solos /Sedimentos}

Amostraram-se solos/sedimentos de origem antrópica, localizados nas porções do superficiais do aterro (S1 a S4), associados aos poços de monitoramento (PM1 a PM4).

\subsubsection{Sedimentos das margens}

No Rio Piaçaguera foram amostrados, sedimentos ( $\mathrm{Sd} 1$ e $\mathrm{Sd}$ 2) das margens nos mesmos locais de coleta das amostras de águas superficiais. É importante destacar que foi observada grande quantidade de escória também nas margens do Piaçaguera. 


\subsubsection{Resíduos Sólidos}

Os resíduos oriundos dos processos siderúrgicos são parcialmente vendidos para reciclagem e aqueles não reaproveitados, são depositados na área formando pilhas e posteriormente dispostos na célula do Aterro. Foram coletadas amostras no topo (a), na porção mediana (b) e na base (c) das pilhas (R2) constituída por lama de aciaria e (R3) correspondente ao material grosseiro, rico em escórias (Figuras 5.1.4-1.(a., b)). 
a)

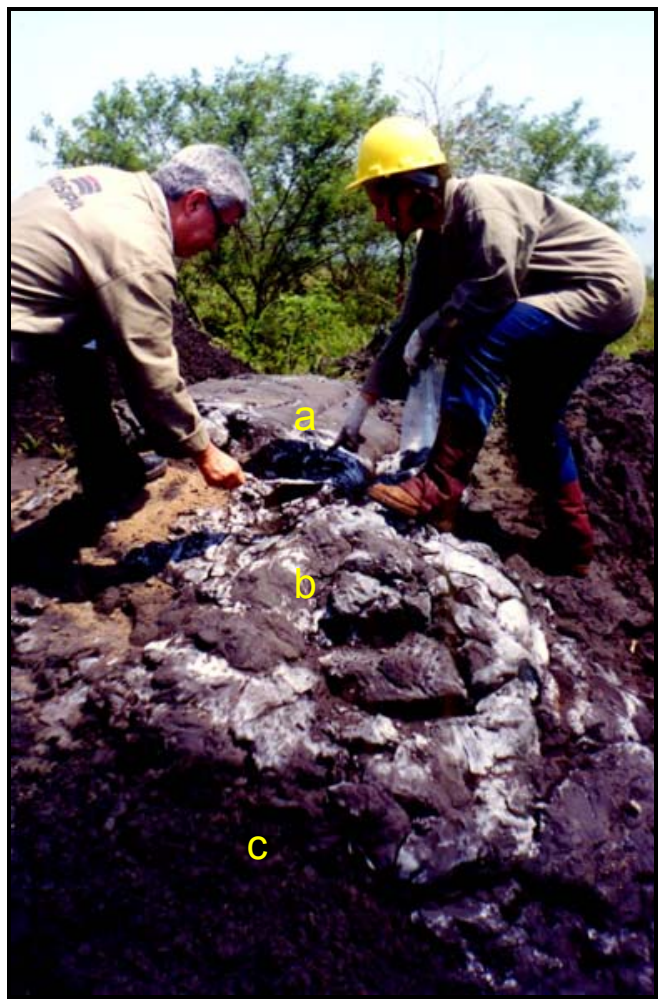

b)

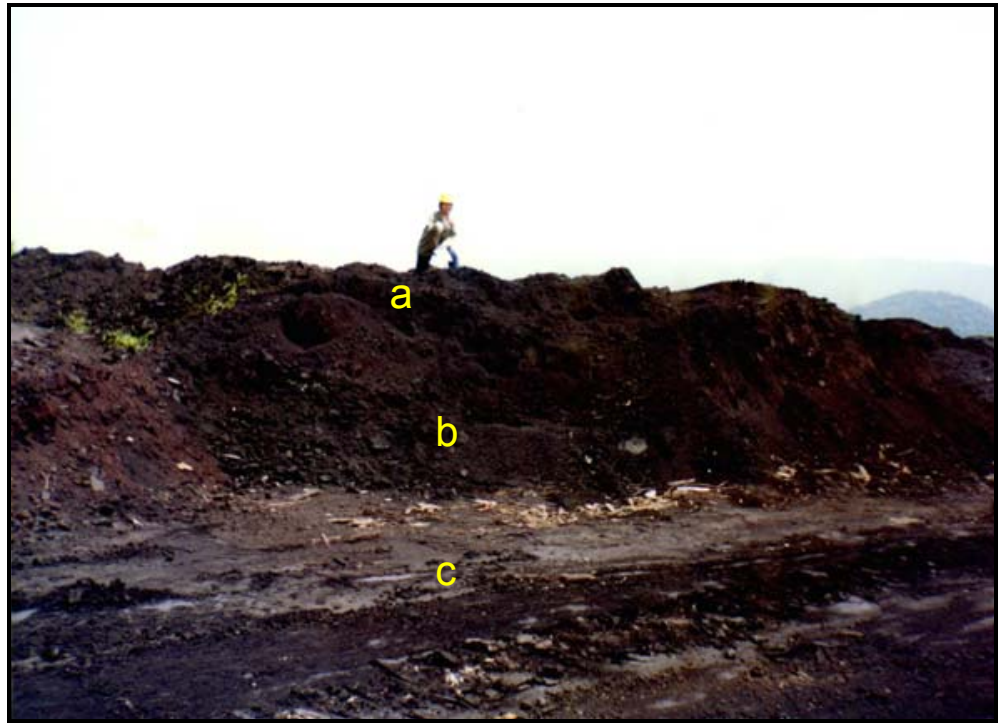

Figuras 5.4.1-1.a : Coleta na pilha de resíduos de lama de aciaria (R2) b: Coleta na pilha de resíduos (R3) de materiais ricos em escórias.

$\mathrm{Na}$ célula do Aterro foram coletadas amostras mistas de resíduos de diferentes naturezas (R1-a, b, c, d), (Figuras 5.4.1-2.(a, b)) que constituíram em uma amostra composta: R1. 
a)

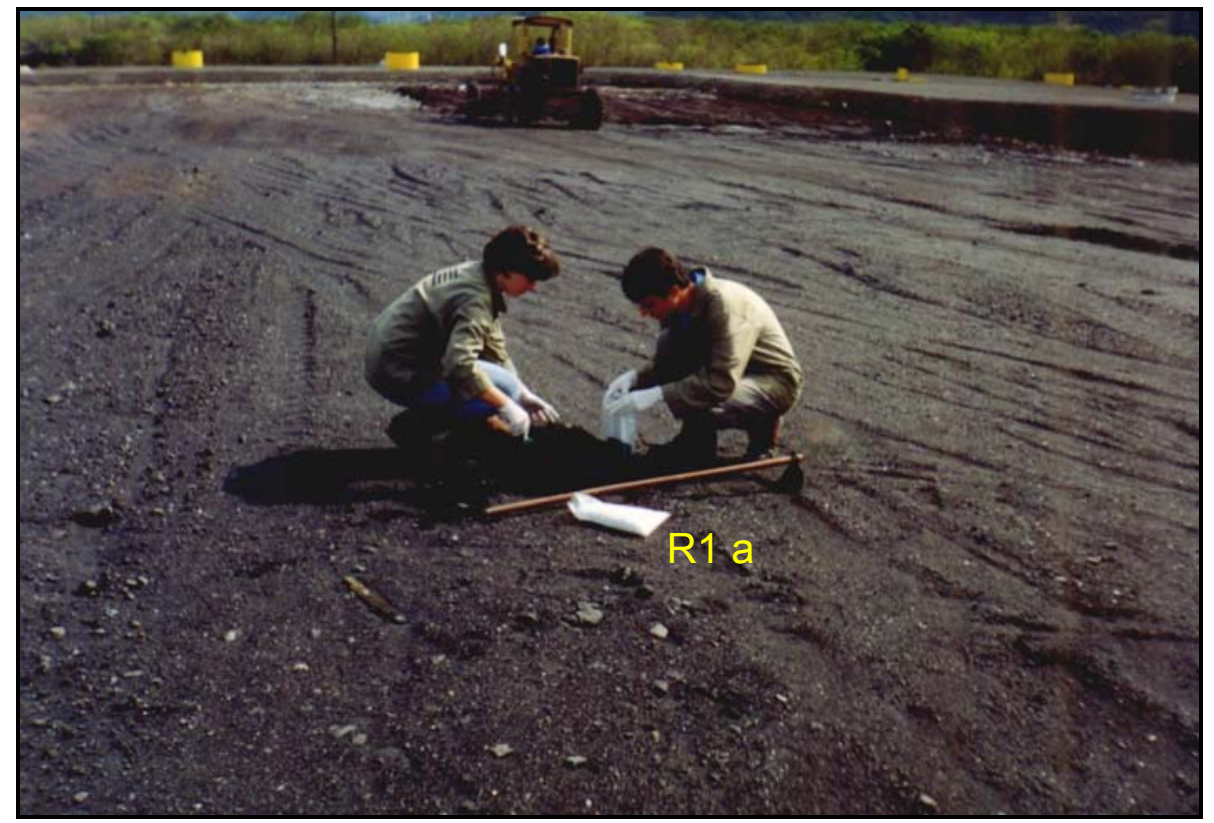

b)

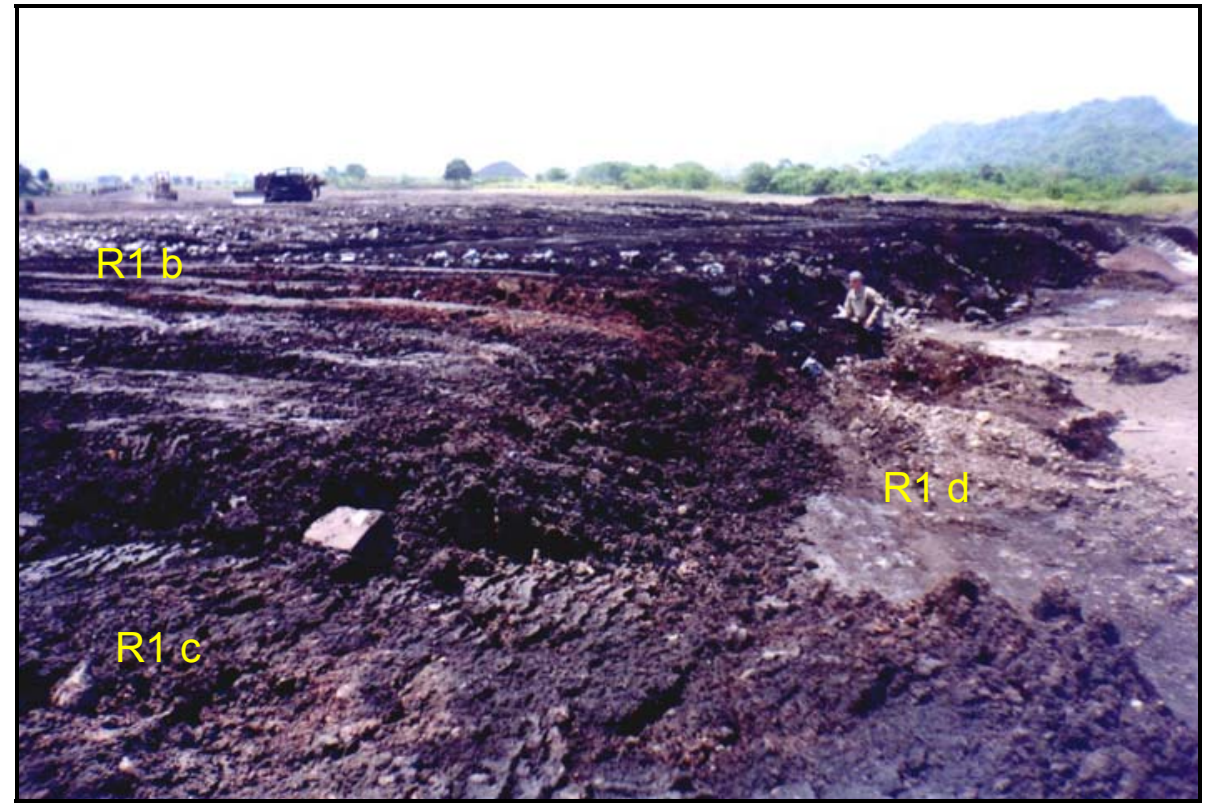

Figura 5.4.1-2.(a).: Coleta de Resíduos (R1) na célula do Aterro . (b): Amostragem em vários pontos da célula que constituíram em uma amostra composta

Foram coletadas também amostras de escórias (ES) (Figura 5.4.1-3), que são reaproveitadas na fabricação de cimento Portland, como lastro em ferrovias e que têm sido utilizadas por mais de 30 anos como material de Aterro em toda a área da Empresa (antigo manguezal). 


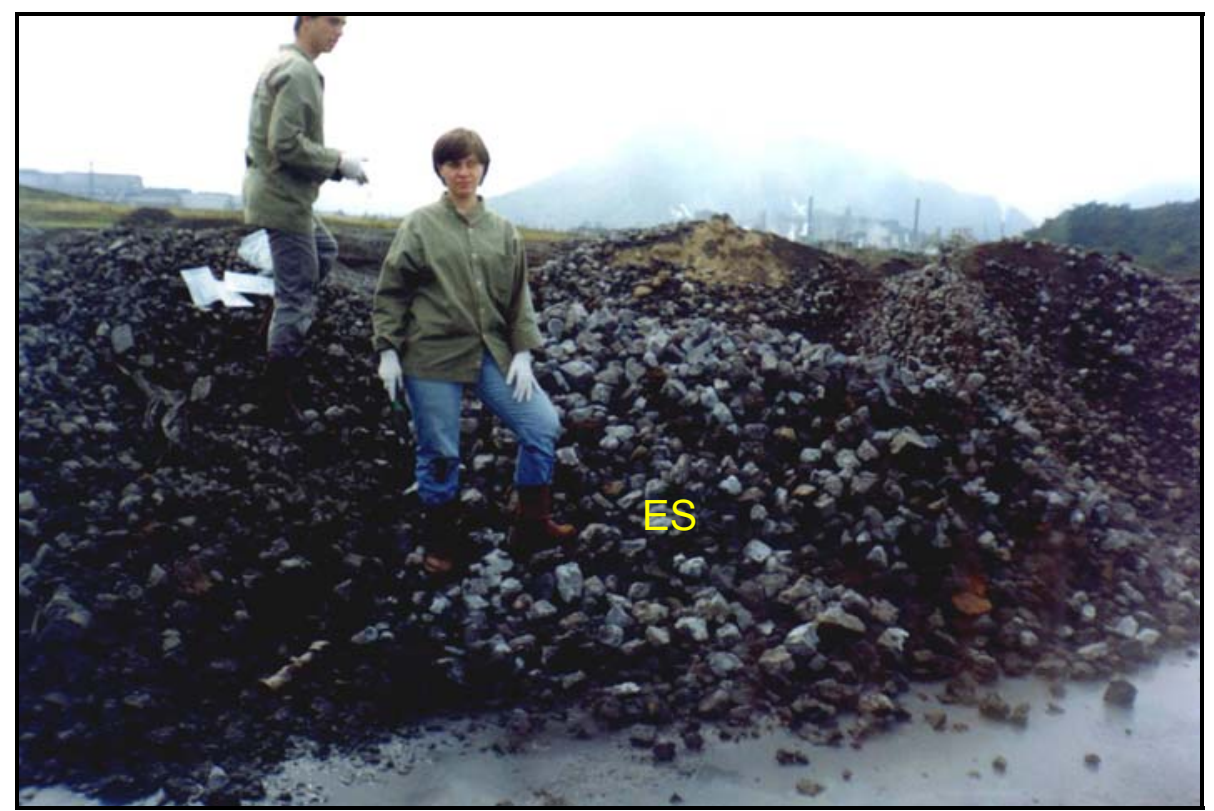

Figura 5.4.1-3.: Amostras de Escória (ES) armazenadas na área do Aterro Industrial

\subsubsection{Efluentes}

Coletaram-se amostras de efluentes, amostra (EF1) no tanque para captação e armazenamento de líquido percolado da célula do Aterro e amostra de lodo (LD) depositado no fundo do tanque sob a forma de lama com espessura de aproximadamente $0,10 \mathrm{~m}$, correspondendo a um volume de $8 \mathrm{~m}^{3}$ de massa (Figura 5.1.5-1). 


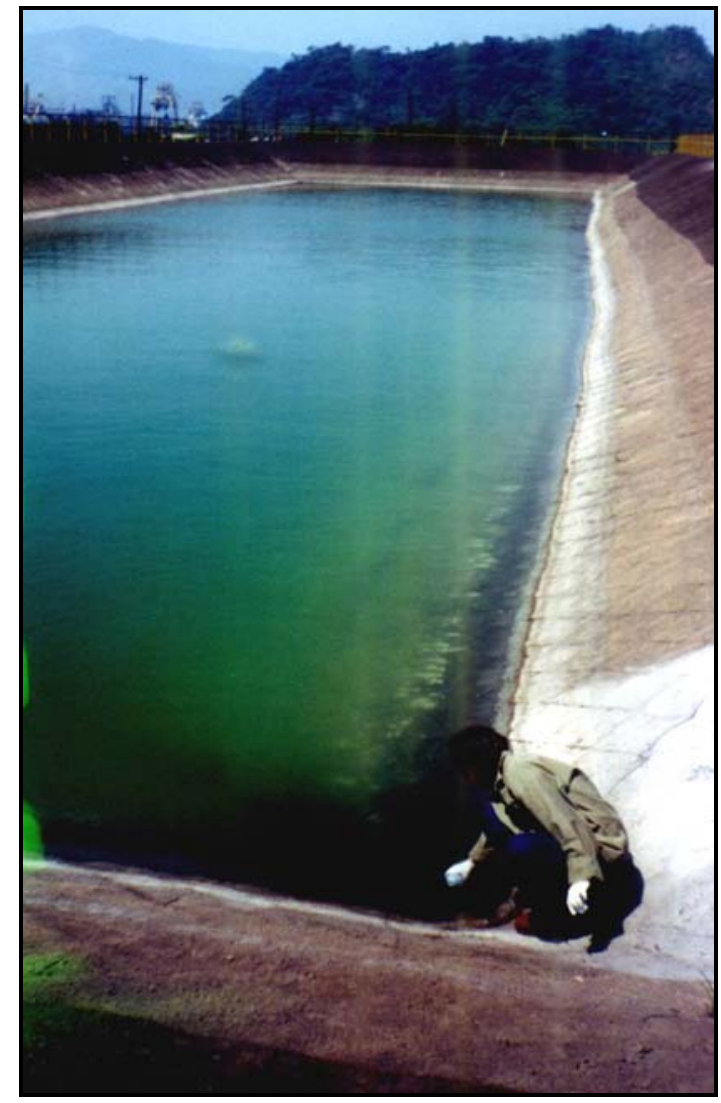

Figura 5.1.5-1.: Tanque para coleta de percolado da Célula do Aterro Industrial (EF1)

As frações líquidas de todo o Aterro são, através de tubulações (drenos), concentradas em um ponto de descarte no Rio Piaçaguera, amostra de efluente EF2. 


\section{MATERIAIS E MÉTODOS}

O estudo do comportamento de íons poluentes associados ao Aterro Industrial da Industria Siderúrgica foi estudado envolvendo trabalhos de campo e laboratoriais.

\subsection{Trabalhos de Campo}

No Município de Cubatão as transições entre inverno e verão são extremamente curtas apresentando altos índices pluviométricos sem real estação seca (CETESB, 1988; Gutberleti, 1996). Desta forma, os trabalhos de campo correspondem a três campanhas de amostragens as quais consistiram de coletas de amostras de águas, efluentes e materiais sólidos do Aterro.

\subsection{1. Águas Subterrâneas e Solos/sedimentos associados aos poços}

Foram coletadas cinco amostras de águas subterrâneas em poços de monitoramento já existentes (PM1 a PM5).

Antes das coletas das águas subterrâneas, com auxílio de bomba peristáltica, os poços de monitoramento foram esgotados, extraindo 3 a 4 vezes o volume de água estagnada e somente após o restabelecimento do nível d'água, com amostrador do tipo bailer, a amostra foi coletada (Figura 6.1.1-1). 


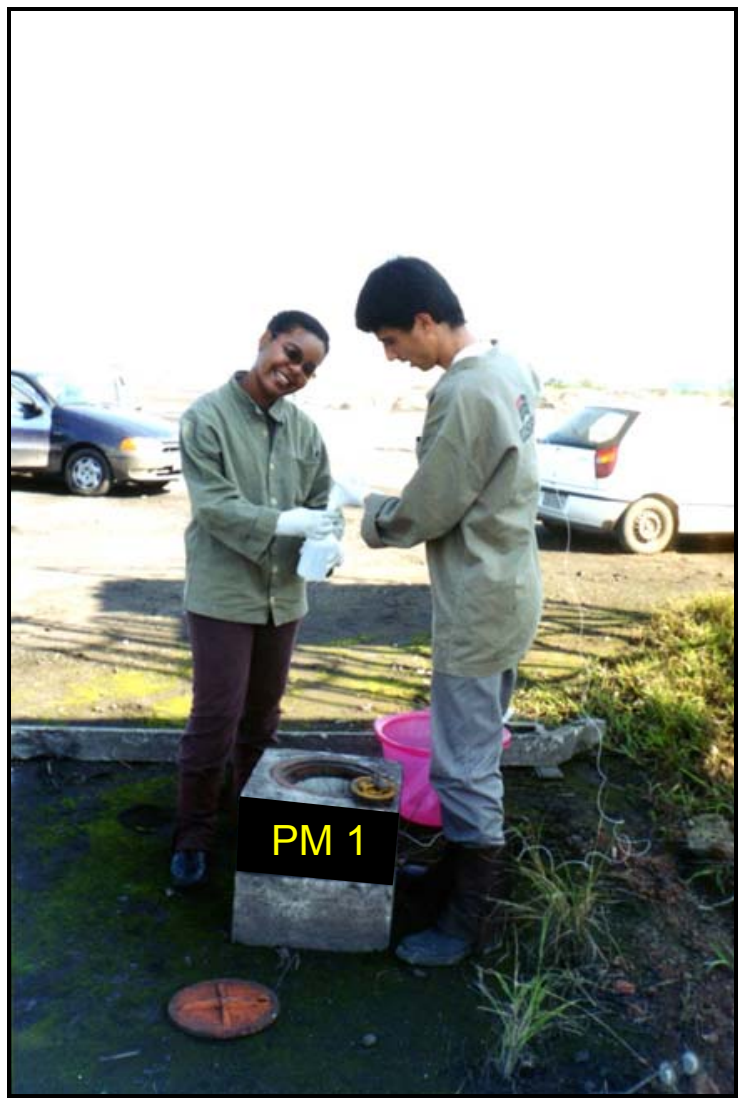

Figura 6.1.1-1: Coleta de água subterrânea do poço de monitoramento PM-1 com amostrador tipo bayler.

Foram amostrados também solos/sedimentos (S1 a S4), associados aos poços de monitoramento (PM1 a PM4) com auxílio de trado manual e pá de polietileno.

\subsection{2. Águas Superficiais e Sedimentos da Margem do Rio Piaçaguera}

Selecionaram-se dois pontos de amostragens representativos para coletas de águas superficiais e sedimentos do Rio Piaçaguera, próximas ao Aterro, a montante (As1) e a jusante (As2). As amostras de águas superficiais foram coletadas manualmente e as amostras de sedimentos amostradas através de trado manual. 


\subsubsection{Resíduos Sólidos}

Os resíduos sólidos foram coletados, utilizando pá de polietileno, na célula do Aterro com amostragens de sub amostras de resíduos de diferentes naturezas e que misturadas e homogeneizadas constituíram-se em uma amostra composta: R1. Dos resíduos armazenados em pilhas na área do Aterro foram coletados amostras no topo, na base e em sua porção mediana; foram coletadas também amostras de escórias (ES).

\subsubsection{Efluentes}

Foram coletadas, manualmente e, com auxílio de pá, o lodo (LD), depositado no fundo do tanque de armazenamento de efluente (EF1) que percola a célula do Aterro.

Ao amostrar águas e efluentes, foram realizadas medidas in situ de $\mathrm{pH}$ e Eh, efetuadas potenciometricamente com eletrodos de vidro e combinado de platina (multiline P3- marca WTW). As leituras foram realizadas após calibrações com tampões 4,00 e 7,00 para pH e $97 \mathrm{mV}$ e $263 \mathrm{mV}$ para Eh. Parâmetros como temperatura e condutividade elétrica foram determinados com Eletrodos Multiline (P3/oxi/cond., marca WTW) e alcalinidade através de metodologia descrita por Hypolito, et. al., 2007.

As amostras líquidas, no momento da coleta, foram filtradas (milipore de $0,45 \mu \mathrm{m}$ ), condicionadas em frascos plásticos com adição de $\mathrm{HNO}_{3}$ e $\mathrm{H}_{2} \mathrm{SO}_{4}$ até $\mathrm{pH}$ $<2$, e as amostras sem a adição de preservantes, após filtradas, foram mantidas em caixa termoisolante a $4{ }^{\circ} \mathrm{C}$ até envio ao Laboratório de Hidrogeoquímica II Centro de Pesquisas de Águas Subterrâneas IGc/USP.

As amostras sólidas (solos, sedimentos e resíduos) foram armazenados em sacos plásticos devidamente lacrados e rotulados para posteriores análises. 


\subsection{TRABalHos LaboratoriaIS}

Para as caracterizações químicas e mineralógicas as amostras foram agrupadas em sólidas e líquidas (águas superficiais, subterrâneas e efluentes).

As amostras sólidas, constituídas por solos, sedimentos da margem, lodo do tanque de armazenamento, resíduos, escórias, minério de ferro, carvão mineral e coque foram secas ao ar livre, destorroadas, quarteadas e homogeneizadas; em seguida foram destinadas às análises químicas dos elementos maiores e traços por Fluorescência de Raios X (FRX), análises mineralógicas por Difratrometria de Raios X (DFX), granulométricas e Capacidade de Troca Catiônica (CTC).

Nas amostras líquidas foram analisados cátions por Espectofotometria de Absorção Atômica (Cg AA 7000 BC) e os ânions por Cromatografia Líquida de ĺon, (Dionex-2010i); nos Laboratórios do Centro de Pesquisas de Águas Subterrâneas IGc/USP.

Para verificação da disponibilidade dos íons metálicos poluentes ao meio ambiente foram realizados testes de dissolução, nas amostras sólidas, com água deionizada, ácidos inorgânicos e com extrator do tipo soxhlet. Devido ao fato da área localizar-se em região de manguezal e sofrer influência de maré foram realizados também ensaios laboratoriais para verificação do efeito da força iônica na liberação dos íons metálicos poluentes para o meio ambiente. 


\section{RESULTADOS}

\subsection{Parâmetros Físico-Químicos Medidos em CAmpo}

A concentração de íons metálicos em águas naturais acha-se intimamente associado aos fenômenos de sorção (adsorção e absorção), dessorção ou seja, precipitação/dissolução, óxido-redução, complexação etc. Estes fenômenos, por sua vez, encontram-se na dependência de parâmetros como $\mathrm{pH}$, potencial redox, condutividade elétrica, alcalinidade que são apresentados nas Tabelas de 7.1.1 a 7.1.3.

Tabela 7.1-1: Parâmetros físico-químicos das águas dos poços de monitoramento (PM1 a PM5)

\begin{tabular}{l|c|c|c|c|c} 
Amostras & $\mathrm{pH}$ & Eh $(\mathrm{V})$ & $\begin{array}{c}\text { Temperatura } \\
\left({ }^{\circ} \mathrm{C}\right)\end{array}$ & $\begin{array}{c}\text { Condutividade } \\
\text { Elétrica } \\
\left(\mathrm{ms} \mathrm{cm}^{-1}\right)\end{array}$ & $\begin{array}{c}\text { Alcalinidade } \\
\left(\mathrm{mg} \mathrm{dm}^{-3} \mathrm{CaCO}_{3)}\right.\end{array}$ \\
\hline PM1 & 6,85 & $-0,06$ & 26,20 & 20,90 & 138,00 \\
\hline PM2 & 6,47 & $-0,33$ & 24,30 & 23,50 & 13,00 \\
\hline PM3 & 6,78 & $-0,31$ & 23,80 & 26,50 & 190,00 \\
\hline PM4 & 12,44 & $-0,38$ & 26,60 & 8,91 & 406,00 \\
\hline PM5 & 6,89 & $-0,08$ & 24,40 & 18,30 & 150,00 \\
\hline
\end{tabular}

Tabela 7.1-2.: Dados físico-químicos, a montante (As1) e a jusante (As2), das águas do Rio Piaçaguera

\begin{tabular}{l|c|c|c|c|c} 
Amostras & $\mathrm{pH}$ & $\mathrm{Eh}(\mathrm{V})$ & $\begin{array}{c}\text { Temperatura } \\
\left({ }^{\circ} \mathrm{C}\right)\end{array}$ & $\begin{array}{c}\text { Condutividade } \\
\text { Elétrica } \\
\left(\mathrm{ms} \mathrm{cm}^{-1}\right)\end{array}$ & $\begin{array}{c}\text { Alcalinidade } \\
\left(\mathrm{mg} \mathrm{dm}^{-3} \mathrm{CaCO}_{3)}\right.\end{array}$ \\
\hline As1 & 7,97 & 0,15 & 21,00 & 27,80 & 62,00 \\
\hline As2 & 7,31 & $-0,20$ & 22,70 & 30,30 & 26,00 \\
\hline
\end{tabular}


Tabela 7.1-3.: Medidas físico-químicas dos efluentes depositado no tanque (EF1) e da tubulação de descarte no Rio Piaçaguera (EF2).

\begin{tabular}{l|c|c|c|c|c} 
Amostras & $\mathrm{pH}$ & Eh (V) & $\begin{array}{c}\text { Temperatura } \\
\left({ }^{\circ} \mathrm{C}\right)\end{array}$ & $\begin{array}{c}\text { Condutividade } \\
\text { Elétrica } \\
\left(\mathrm{ms} \mathrm{cm}^{-1}\right)\end{array}$ & $\begin{array}{c}\text { Alcalinidade } \\
\left(\mathrm{mg} \mathrm{dm}^{-3} \mathrm{CaCO}_{3)}\right.\end{array}$ \\
\hline 王1 & 9,74 & 0,02 & 22,30 & 0,22 & 30,00 \\
\hline 王 & 6,79 & 0,03 & 22,60 & 8,26 & 43,00 \\
\hline
\end{tabular}

Os valores de $\mathrm{pH}$ das águas subterrâneas foram praticamente constantes (média de 7,89), com exceção da amostra do poço PM 4 com pH 12,44, devido a natureza dos materiais associados a ele formados de as escórias recém depositadas.

$\mathrm{O}$ forte odor de $\mathrm{H}_{2} \mathrm{~S}$ em praticamente todo o ambiente do Aterro, mesmo afastado do manguezal preservado, atesta a presença de sulfetos, principais responsáveis pelas condições redutoras das águas dos poços perfurados.

Os valores teóricos de salinidade, calculados através da condutividade elétrica, permitem que se classifiquem as águas subterrâneas do aterro como salgadas (> $3000 \mathrm{mg} \mathrm{dm}^{-3}$, CONAMA, 1986), características de ambiente de manguezal.

As condições de $\mathrm{pH}$ dos poços de monitoramento indicam predomínio de bicarbonato $\left(\mathrm{HCO}_{3}^{-}\right)$exceto no poço PM 4 onde são estáveis os carbonatos.

Nas amostras de águas superficiais verificou-se que a coletada a montante do Aterro (As1) apresentou valor de $\mathrm{pH}$ mais elevado em relação à amostra a jusante (As2), no entanto, o íon bicarbonato é a forma dominante nestes valores de $\mathrm{pH}$ ambas apresentaram teores elevados de condutividade elétrica. O potencial de óxido-redução indicou ambiente redutor na amostra As2, provavelmente relacionado ao descarte de efluente gerado no Aterro diretamente no Rio Piaçaguera.

Os efluentes apresentaram características distintas: o material descartado no Rio Piaçaguera (EF2) possui pH mais baixo decorrente do movimento líquido, com maior contato com o ar atmosférico e conseqüentemente a transferência de dióxido de carbono da atmosfera para a solução; o pH ácido favorece a presença 
de maiores concentrações de sais em solução evidenciado pelo maior valor da condutividade elétrica.

\subsection{ANÁLISES QUímicAs ÁGUAS SUPERFICIAIS, SUBTERRÂNEAS E EFLUENTES}

Os resultados analíticos das águas superficiais, subterrâneas e efluentes coletadas na área do Aterro Industrial encontram-se nas Tabelas 7.2-1 e 7.2-2 


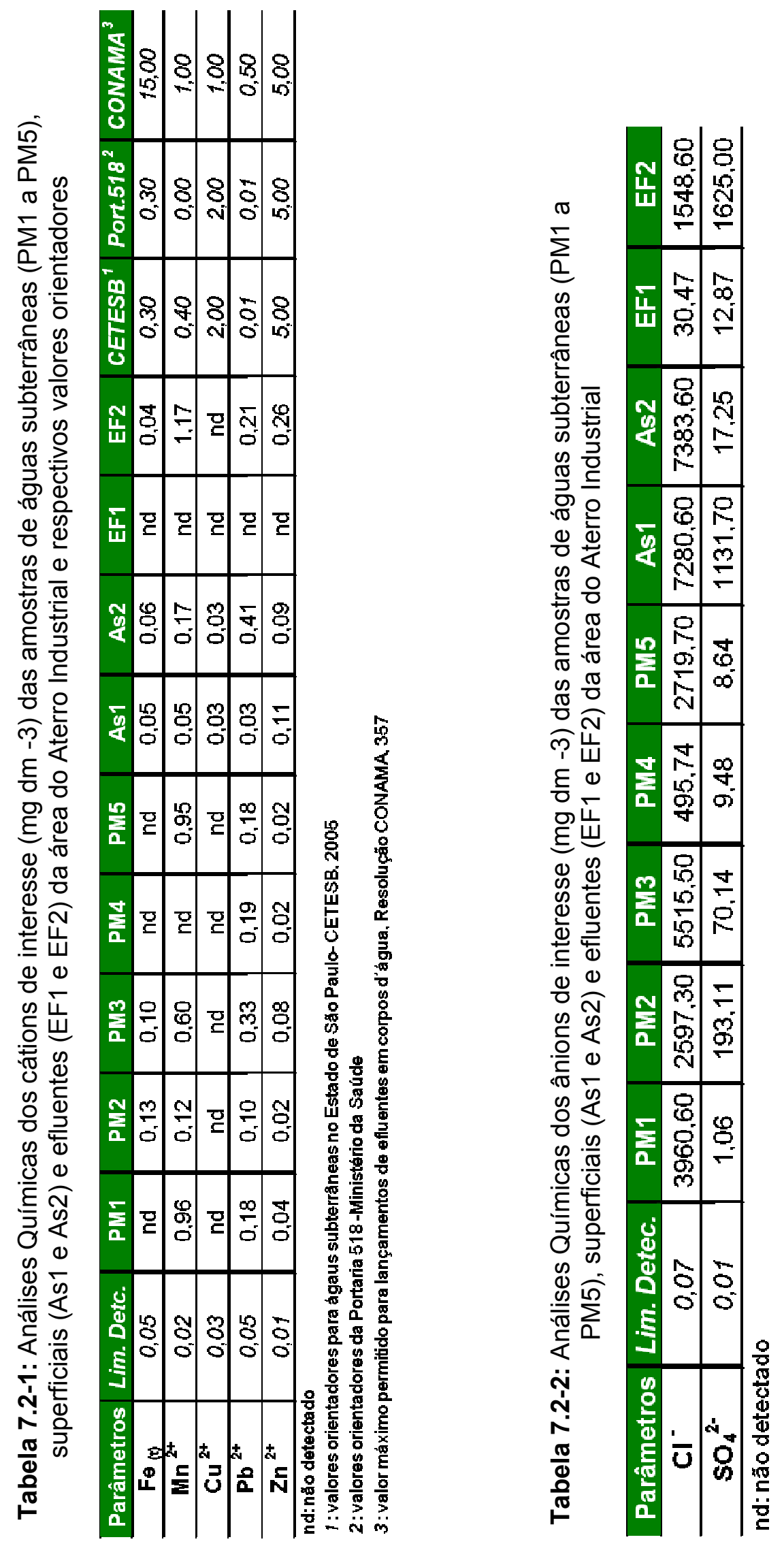


Por localizar-se em região de manguezal e sofrer influência da maré, as águas do Aterro classifica-se como salgada com elevadas concentrações de cloretos e sulfatos (Tabela 7.2.-2).

As concentrações dos íons metálicos de interesse neste trabalho, como o ferro, manganês, cobre, chumbo e zinco apresentaram-se baixas; no entanto com teores acima dos valores de referência, utilizados neste trabalho, apresentando riscos potenciais a saúde humana.

As elevadas concentrações de cloreto e sulfato nos poços se deve à água do mar e ainda o sulfato como produto da oxidação do enxofre do processo siderúrgico.

A projeção dos valores de pH em função do potencial de óxido-redução (Eh) (Figuras 7.2.-1. a, c ,d, e), mostram equilíbrio dos íons ferro, cobre e zinco com suas formas insolúveis de óxido/hidróxido e sulfatos. Os íons manganês mostram sua estabilidade na forma iônica reduzida como $\mathrm{Mn}^{2+}$ e o chumbo produto de oxidação do sulfeto a sulfato encontra-se na forma do sal de chumbo aquoso. 

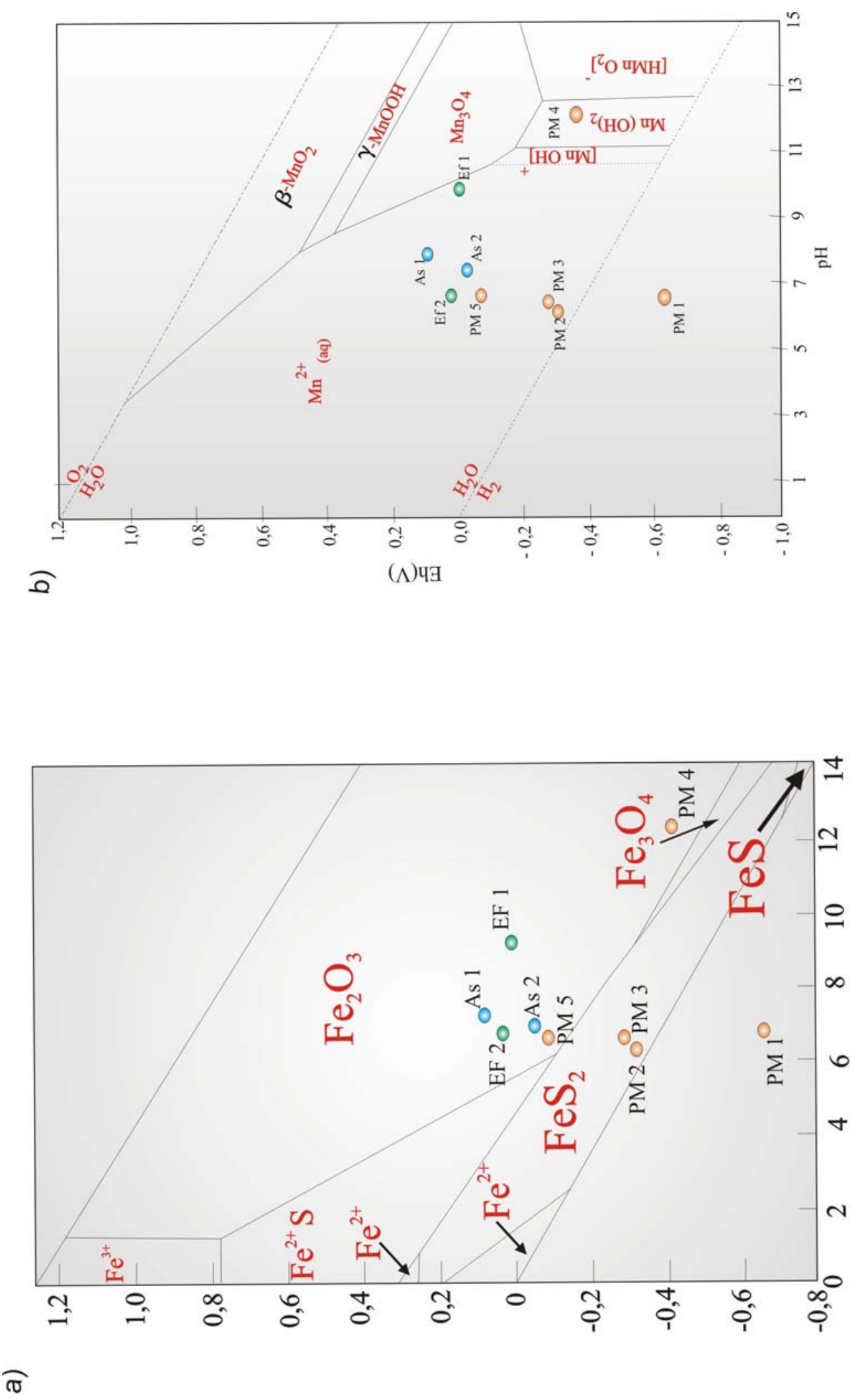

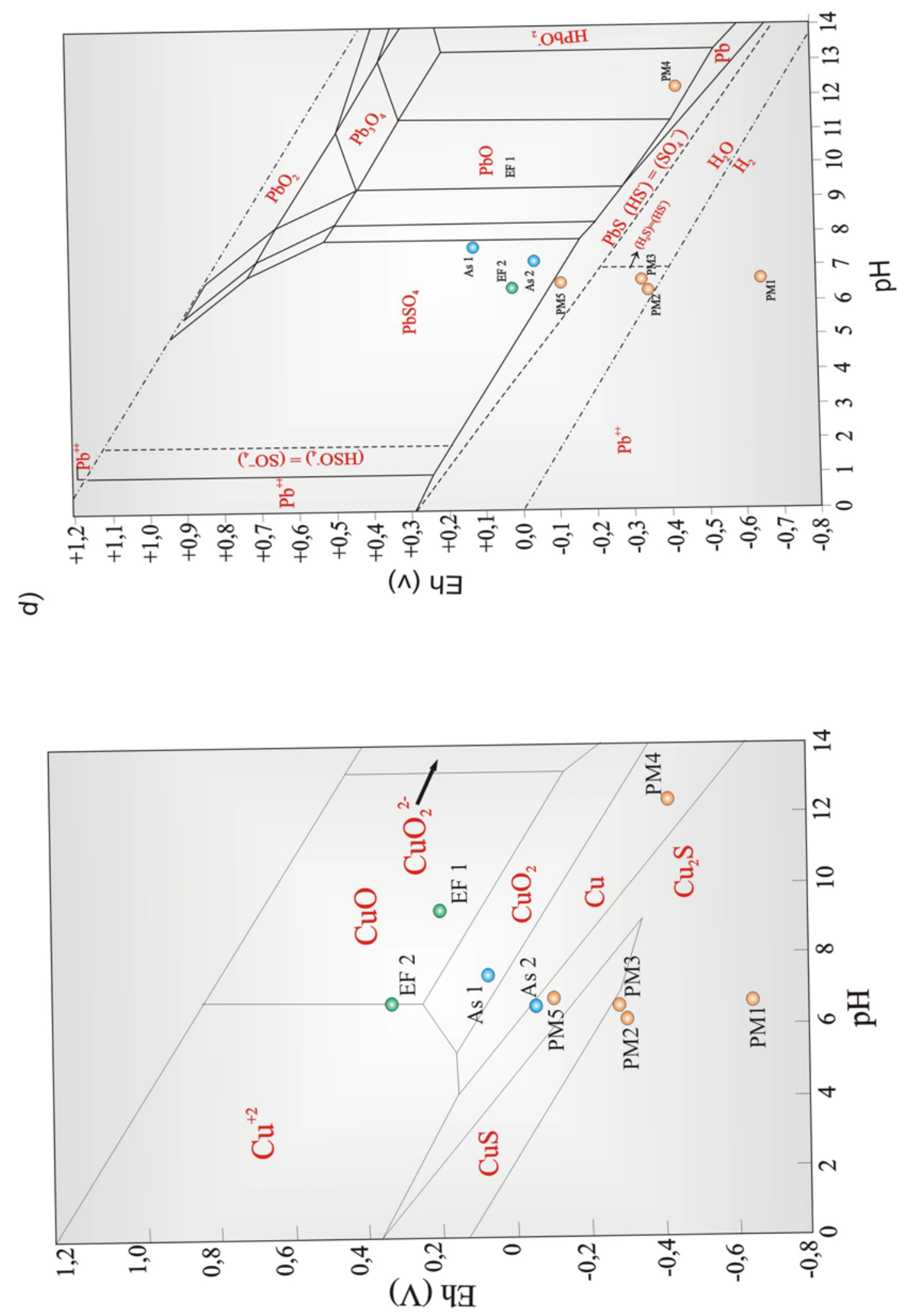

ง 
e)

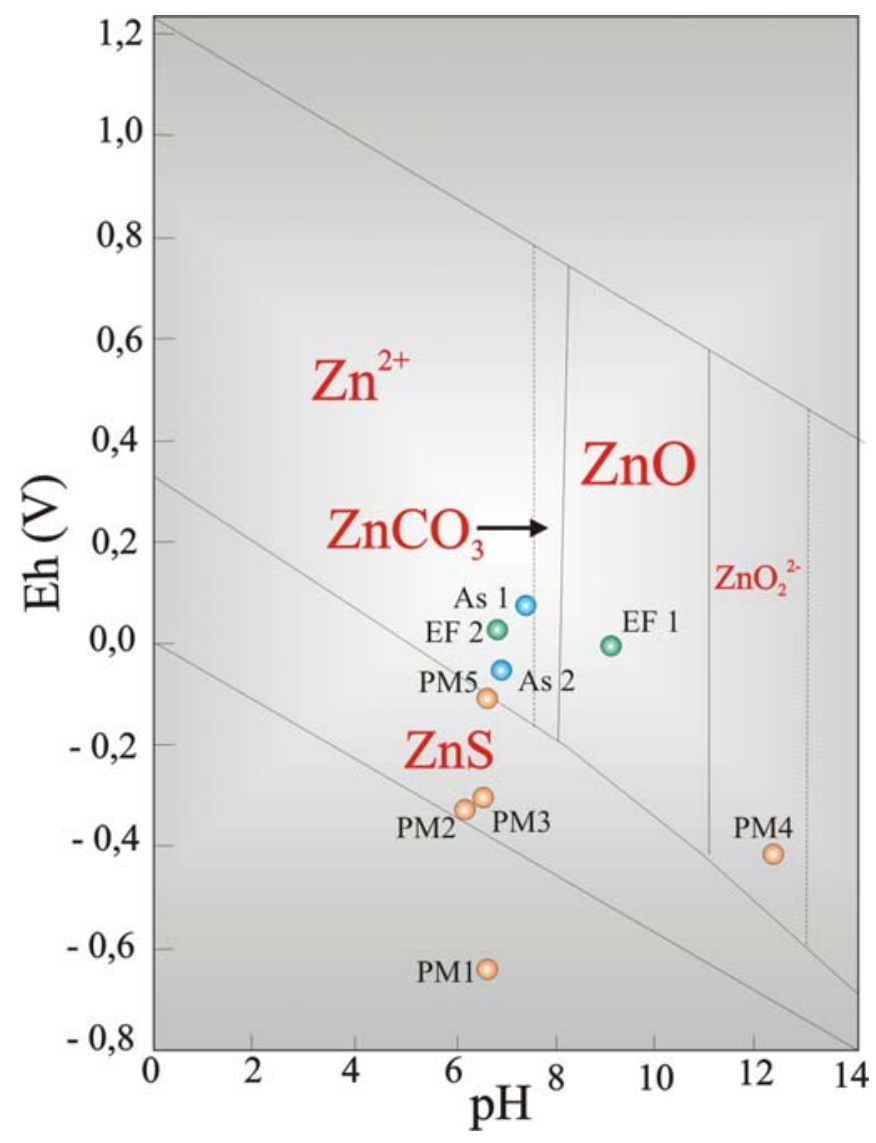

Figura 7.2-1. a-e: Diagramas $\mathrm{pH}=\mathrm{f}(\mathrm{Eh})$ de compostos de ferro, manganês, cobre, chumbo e zinco à $25^{\circ} \mathrm{C}$ e 1 atm., com projeção dos valores das águas subterrâneas (PM1 a PM5), águas superficiais (As1 e As2) e efluentes (EF1 e EF2). Fonte: modificado de Garrels et al., 1965; Hypolito, 1980 e Brookins, 1988. 


\subsection{Análise Granulométrica de Sedimentos da Margem do Rio PIAÇAguera}

Os materiais coletados à margem do Rio Piaçaguera foram analisados granulometricamente pelo método de pipetagem e peneiramento com eliminação prévia da matéria orgânica com água oxigenada. As análises foram realizadas nos laboratórios de Geoquímica do DGSA, IGc-USP (Tabela 7.3-1.).

Tabela 7.3-1.: Resultados das análises granulométricas de sedimentos da margem do Rio Piaçaguera coletadas a montante (Sd1) e jusante (Sd2) nos limites do Aterro.

\begin{tabular}{l|c|c|c}
\hline Amostra & Argila (\%) & Silte (\%) & Areia (\%) \\
\hline Sd1 & 37,7 & 55,18 & 7,12 \\
\hline Sd2 & 10,44 & 50,12 & 39,44 \\
\hline
\end{tabular}

Os resultados foram projetados em diagrama triangular (Figura 7.3-1.) e classificados segundo Sheppard (1954).

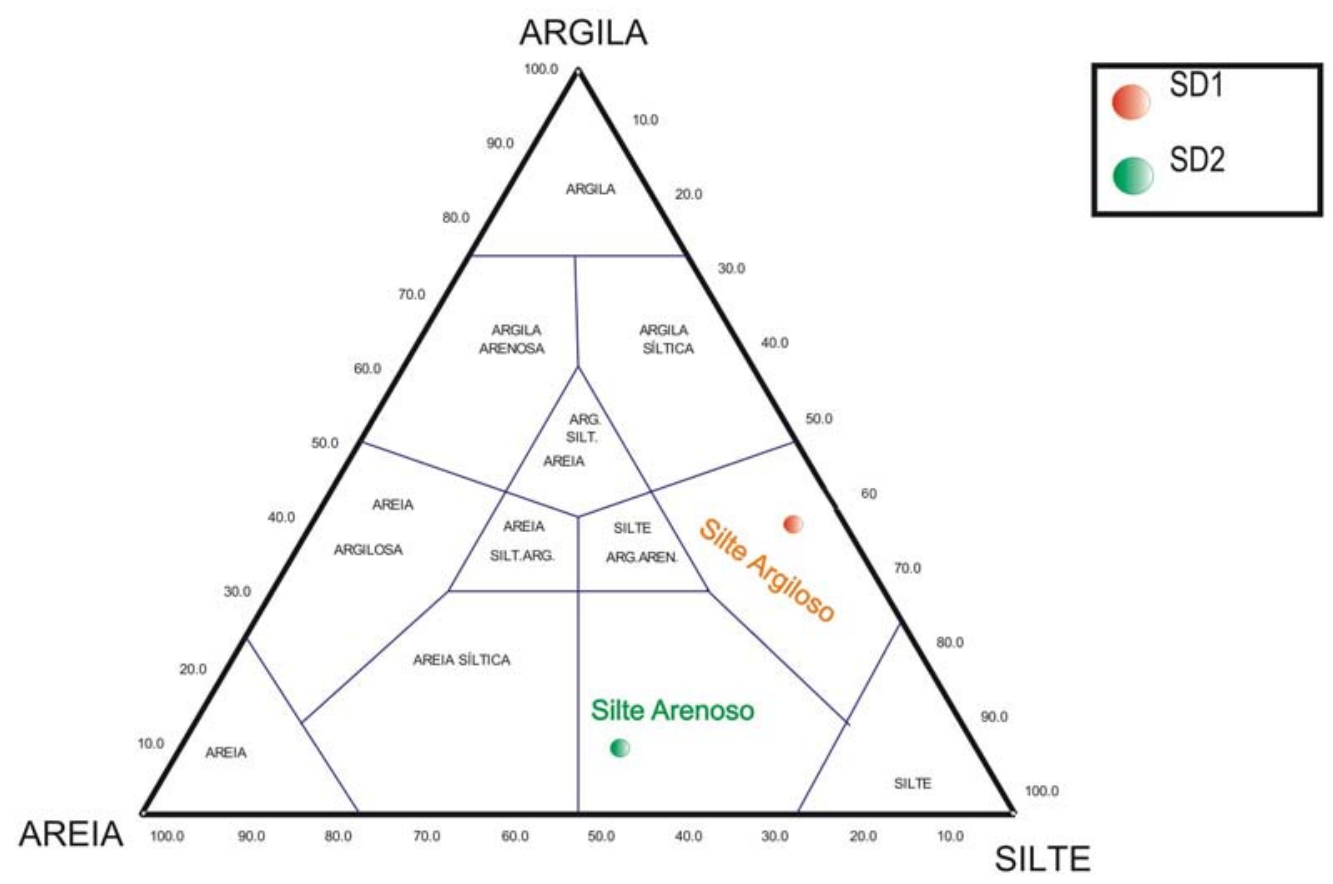

Figura 7.3-1: Projeção das amostras de sedimentos da margem do Rio Piaçaguera em Digrama Triangular de Sheppard (1965). 
As análises granulométricas das amostras de sedimentos do Rio Piaçaguera apresentam predominância da fração silte, classificadas como silte argiloso (Sd1) e silte arenoso (Sd2).

Os solos de manguezal são influenciados por processos físicos como, por exemplo, transporte de partículas grosseiras por tração e por suspensão de partículas de argila e silte que sedimentam pela ação mecânica dos movimentos das correntes de marés (fluxo e refluxo) (Ferreira, 2006).

Segundo Ukpong (1997), o predomínio da fração silte é freqüente em canais de marés e canais distribuitários (canais que distribuem águas) devido às inundações diurnas e deposição ativa de sedimentos transportados pela água. Nesses locais a força da maré é branda e a velocidade de correntes é baixa.

\subsection{ANÁLISES Mineralógicas}

Os materiais sólidos do Aterro; após serem secos foram destorroados e quarteados, moídos em moinho de anel foram analisados por Difratometria de Raios $X$ nos laboratórios do DMG, IGc-USP. Os resultados apresentados nas figuras a seguir correspondem a produtos análogos aos minerais correspondentes, exceto hematita que é de origem natural.

Na Figura 7.4-1.(a, b) encontram-se os resultados de DRX dos sedimentos do Rio Piaçaguera. 
a)

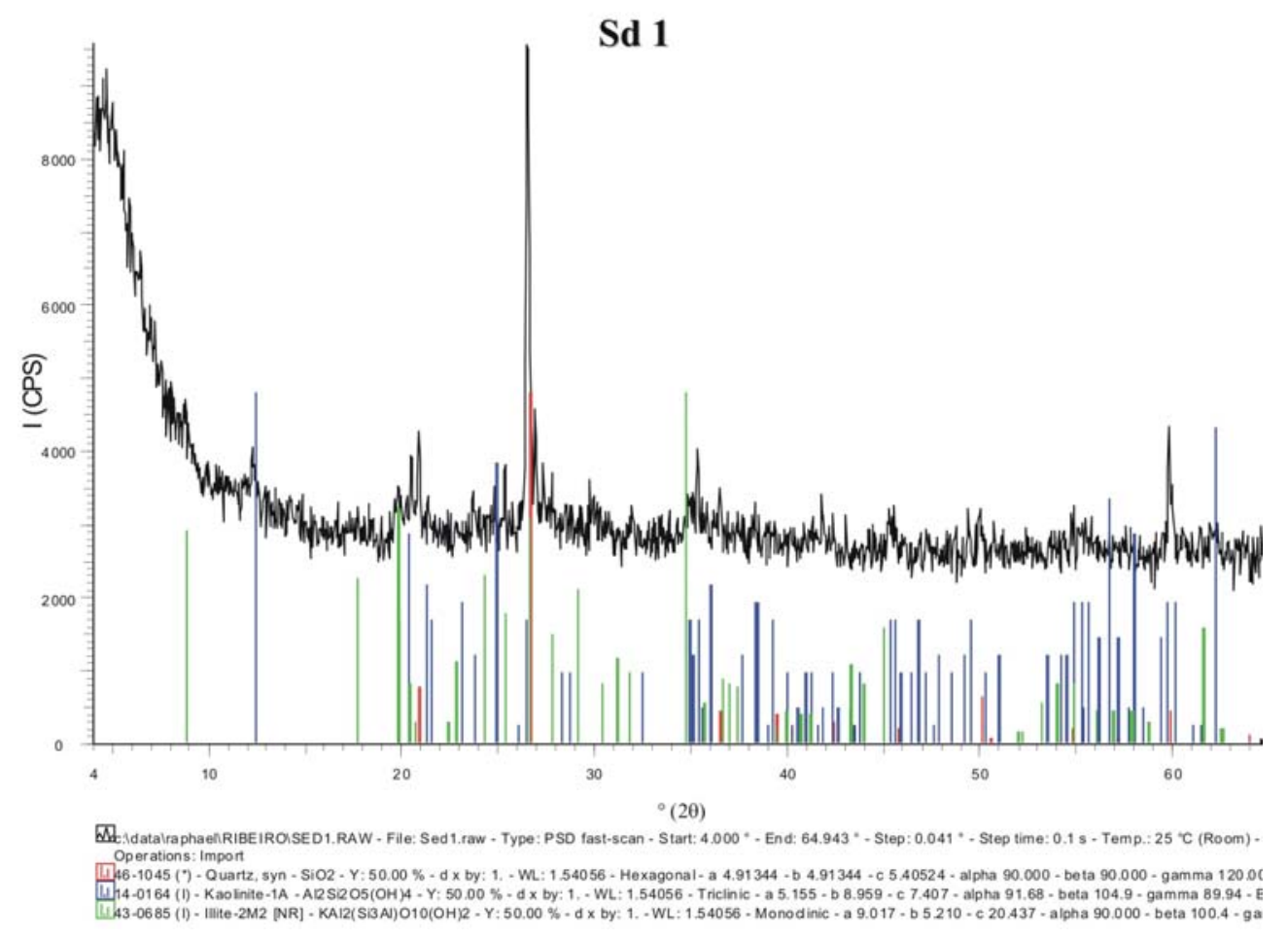

b)

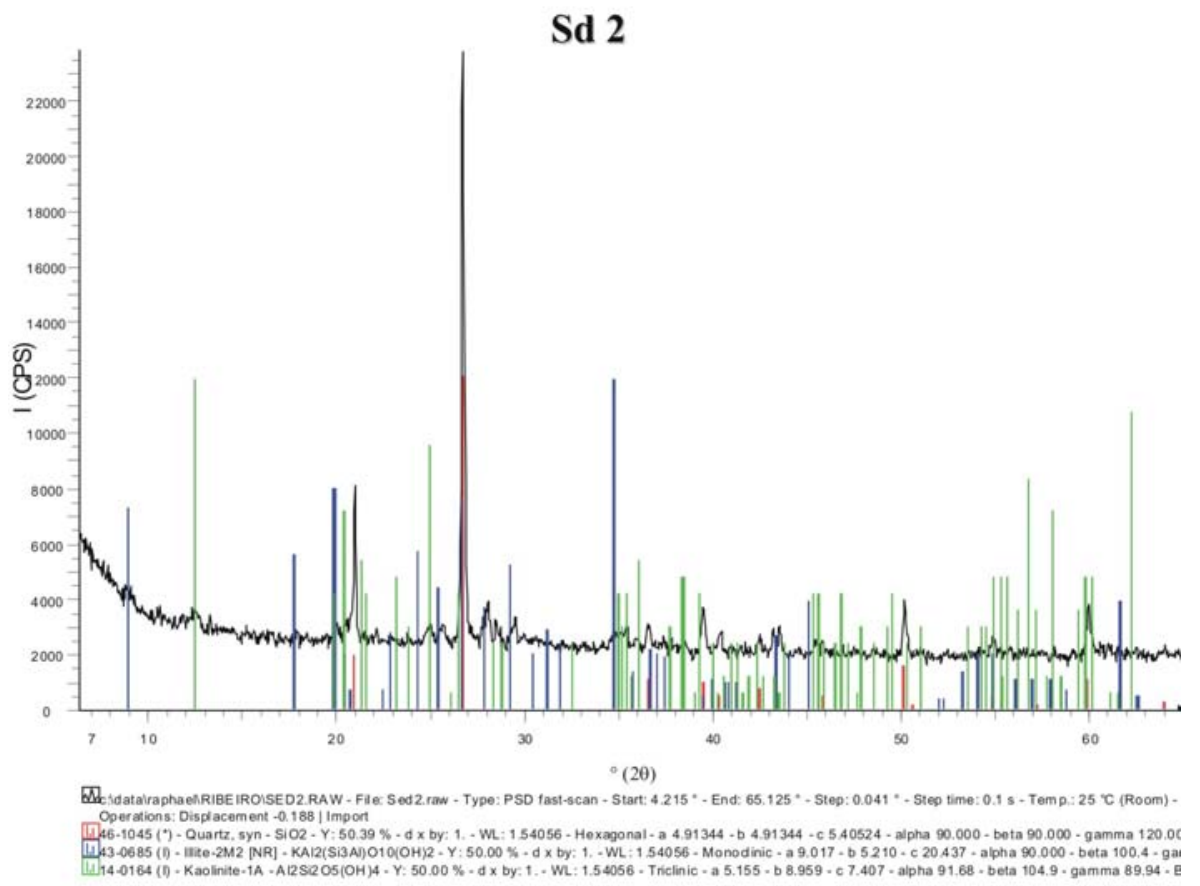

Figuras 7.4-1. a e b: DRX de sedimentos da margem do Rio Piaçaguera a jusante (a) e a montante dos limites do Aterro (b). 
Segundo Prakasa e Swamy (1987) a mineralógia dos solos de manguezal corresponde principalmente a montmorillonita, caulinita, illita e clorita; minerais como quartzo, halita e jarosita também podem compor a assembléia mineralógica desses solos; outros autores consideram a presença de carbonatos incluindo a aragonita e calcita.

Nas amostras dos sedimentos da margem do Rio Piaçaguera foram detectados apenas quartzo, caulinita e illita. Segundo Gameiro (2001), a intensa precipitação e a distribuição pluviométrica irregular que ocorre ao longo do ano na área de estudo favorecem formação destes minerais. A caulinita seria transportada pelos sistemas fluviais e marinhos até os sedimentos dos manguezais adjacentes, seria, portanto, de origem alóctone.

A mica presente nos sedimentos, no caso a illita, a exemplo da caulinita, é oriunda do intemperísmo das rochas granito-gnássicas da Serra do Mar, o que caracteriza também origem alóctone.

O difratograma do minério de ferro é mostrado na Figura 7.4-2.

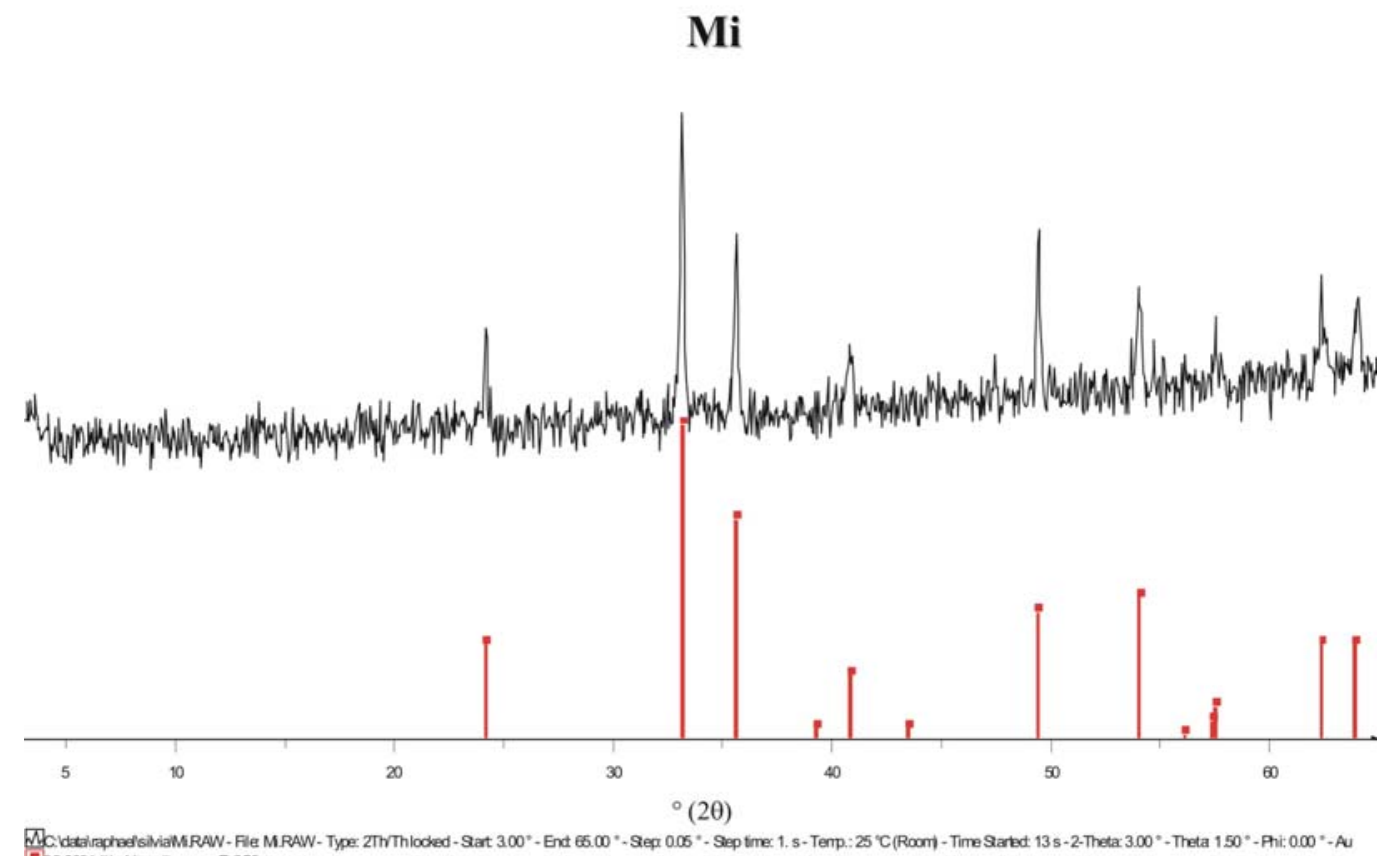

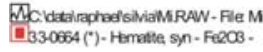

Figura 7.4-2.: Difratometria de Raios $X$ da amostra do minério de ferro utilizado pela Siderúrgica como matéria prima para fabricação do aço. 
A análise difratométrica do minério de ferro indica constitui-se essencialmente de hematita.

Nas Figuras 7.4-3. a, b, c são apresentados os difratogramas das amostras de resíduos R1 (célula do Aterro), R2 e R3 (pilhas de resíduos).

a)

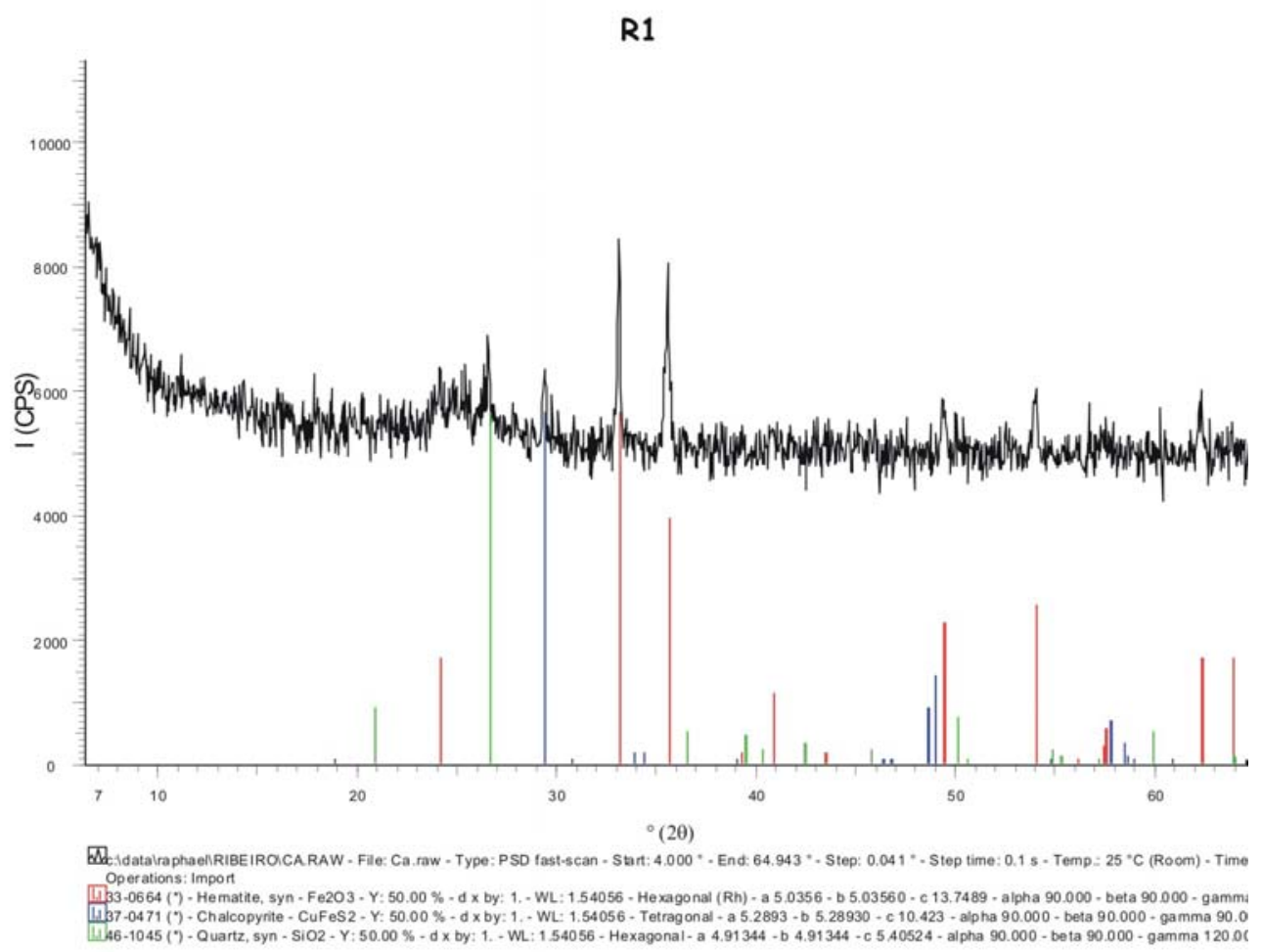


b)

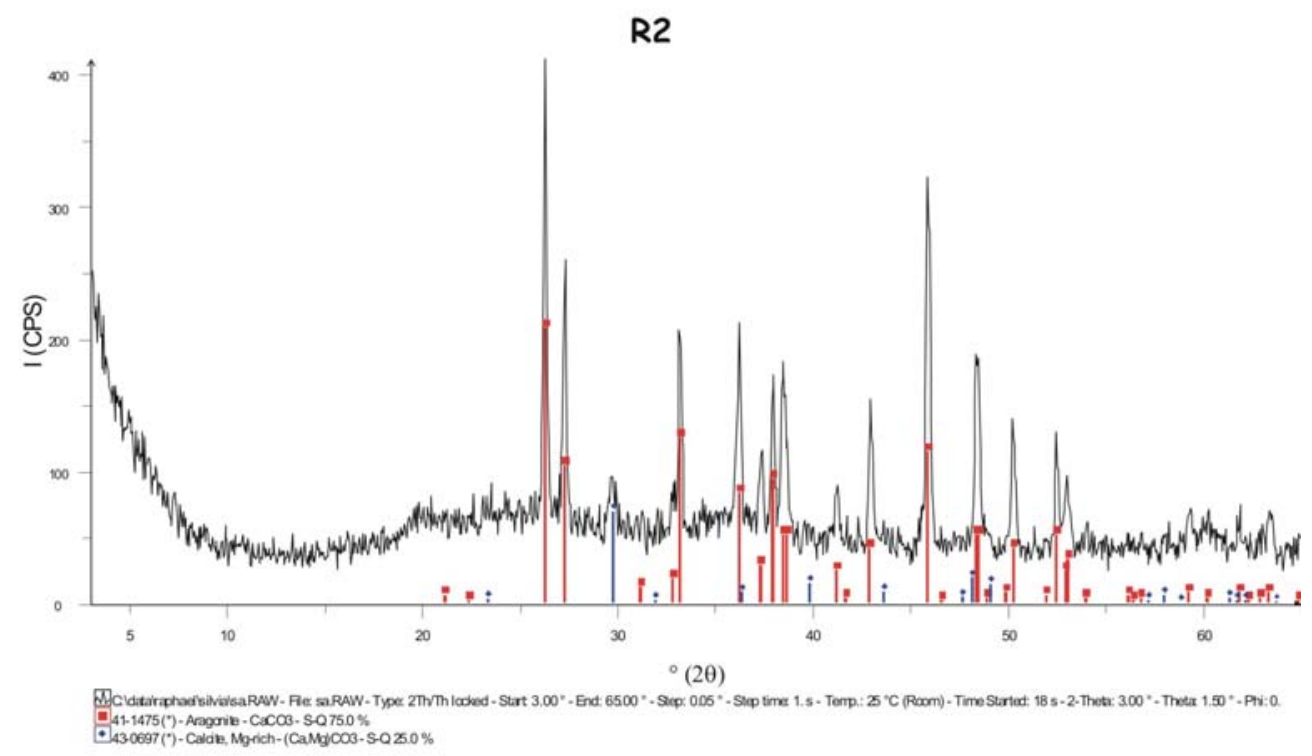

c)

R3

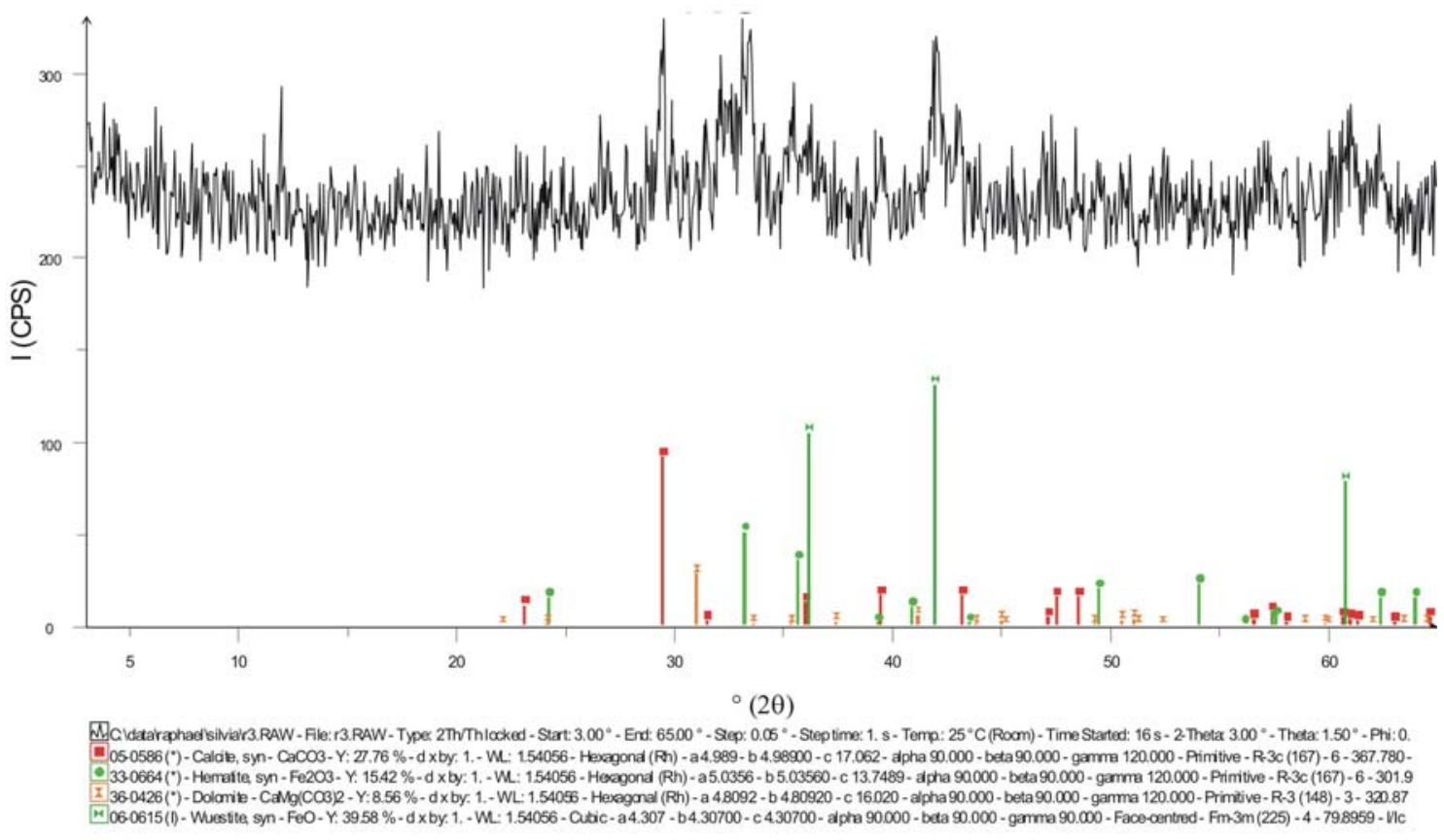

Figuras 7.4-3. a, b, c: Amostras de resíduos depositados na célula do Aterro (R1), e daqueles dispostos na área formando pilhas (R2) (R3) . 
As amostras constituem, essencialmente, de minerais carbonáticos como calcita, dolomita e aragonita.

Detectou-se hematita apenas em R1 e R3, sendo que em R1 também foi detectado mineral resultante de reações de oxidação como calcopirita.

O difratograma da amostra de escória (ES) é apresentado na Figura 7.4-4.

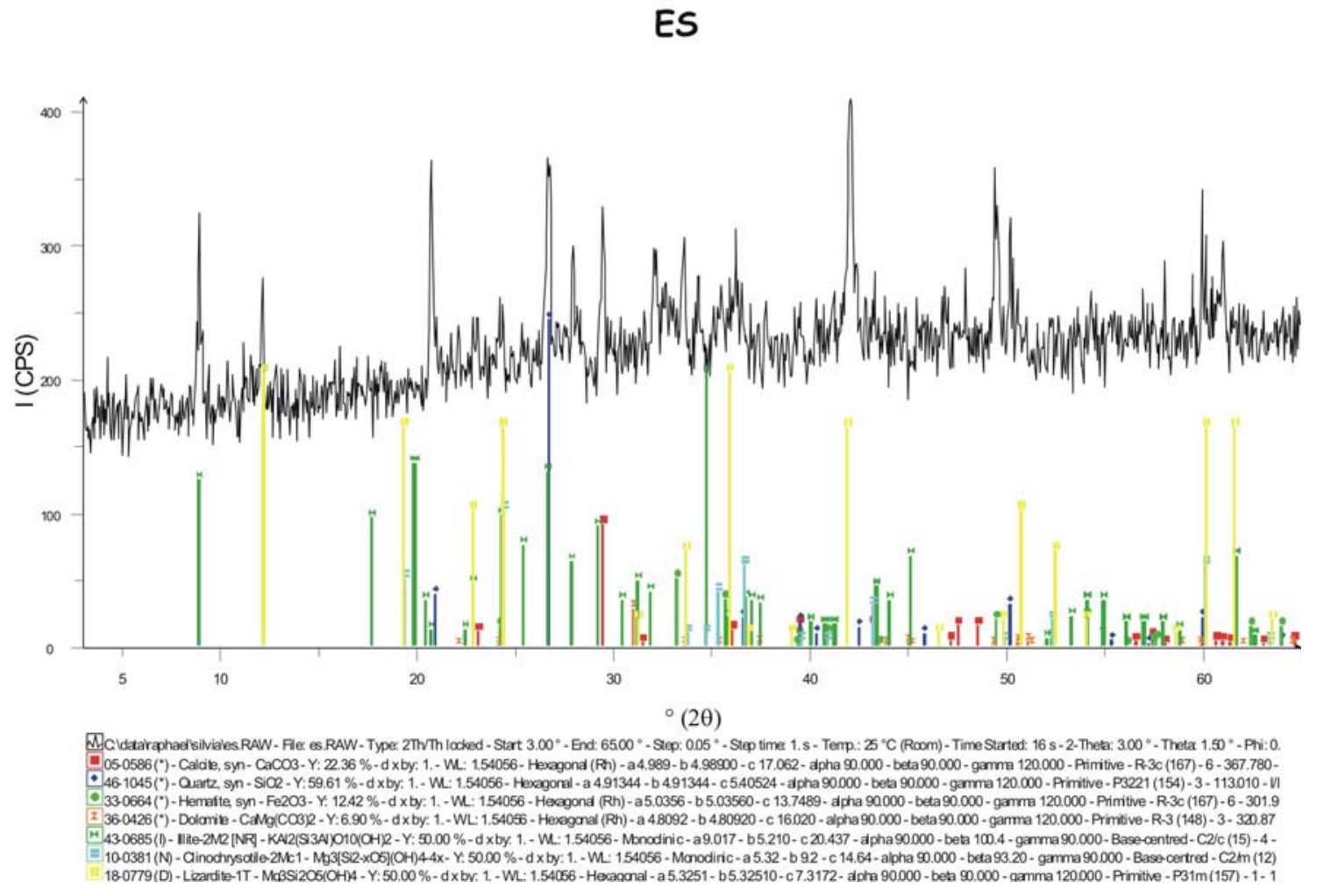

Figura 7.4-4.: Amostra escória produzida no processo de obtenção do ferro gusa

$\mathrm{Na}$ escória a análise difratométrica detectou, principalmente, a presença de minerais carbonáticos como calcita, dolomita e aragonita; estes minerais estão relacionados ao calcário utilizado como fundente na fabricação do aço. É importante destacar que a aragonita é um mineral polimorfo da calcita e apresenta constante de equilíbrio similar em valor, mas difere significativamente devido a estruturas internas desse mineral Em presença de água pura, estes minerais carbonáticos são somente ligeiramente solúveis, aumentando a solubilidade no meio natural, sob influência do ácido carbônico. 
Na Figura 7.4-5 é apresentado o difratograma do material precipitado no tanque de armazenamento de percolado da célula do Aterro.

LD

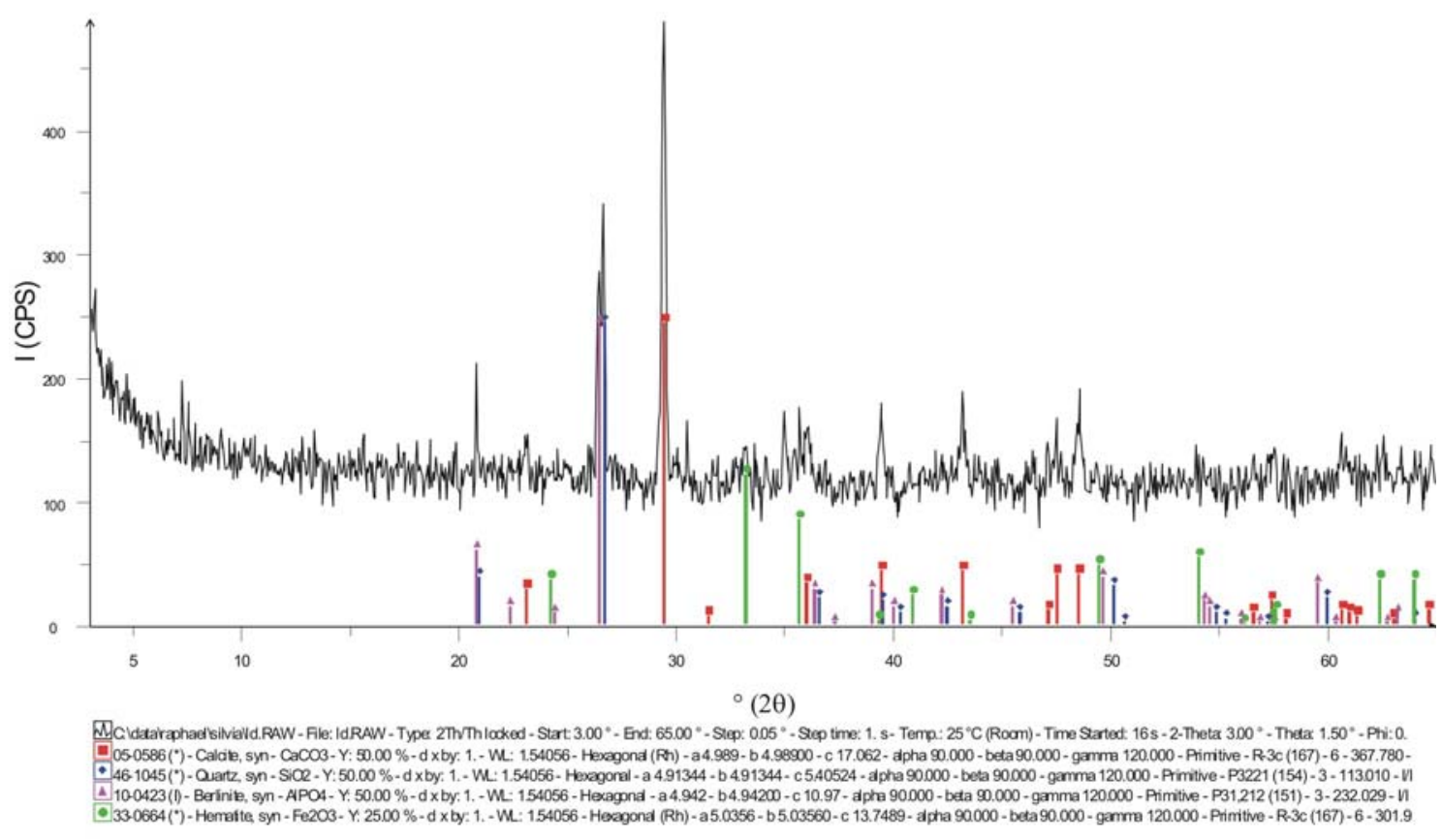

Figura 7.4-5.: Difratograma de amostra de lodo (LD) depositado no tanque de armazenamento de percolado da célula do Aterro

Na amostra de lodo depositado no tanque de captação do efluente percolado na célula do Aterro foram detectados além dos minerais carbonáticos, hematita e quartzo e berlenita - ortofosfato de alumínio- que é comumente encontrado em efluentes industriais; em algumas siderúrgicas, muitas vezes, é utilizado como fundente em substituição ao enxofre. O alumínio é utilizado na remoção do fósforo presente em efluentes, uma vez que seu lançamento direto nos corpos d'água podem causar eutrofização do meio:

$$
\mathrm{Al}^{+3}(\mathrm{aq})+\mathrm{PO}_{4}{ }^{3-}(\mathrm{aq}) \stackrel{\leftrightarrows}{\leftrightarrows} \mathrm{AlPO}_{4}(\mathrm{~s})
$$


O quartzo, presente como impureza no minério de ferro, durante sua fusão deposita-se nos alto-fornos misturando-se às escórias.

As análises difratométricas das amostras de solos/sedimentos, associados aos poços de monitoramento instalados na área do Aterro, encontram-se na Figura 7.4-6. (a,b,c,d)

a)

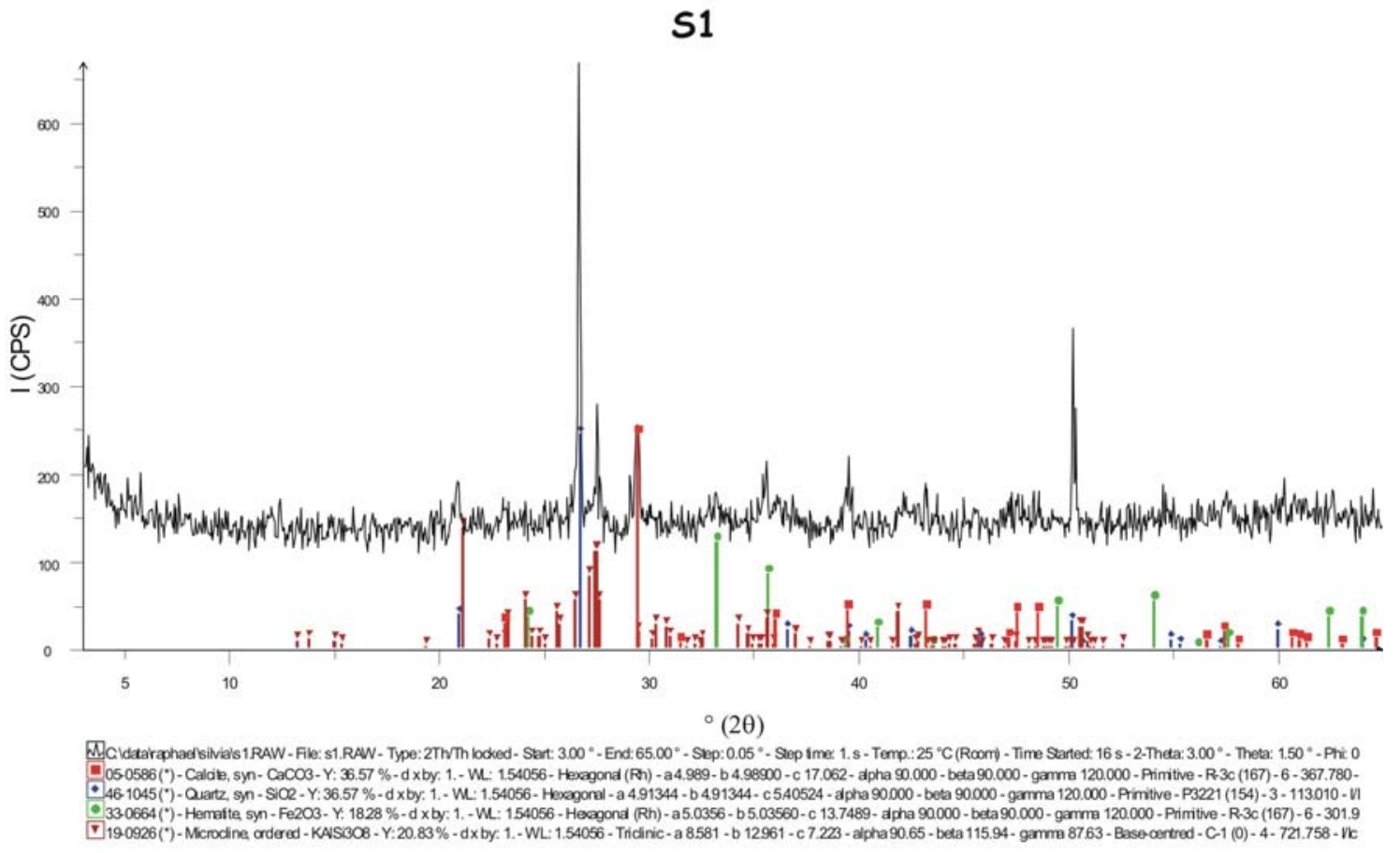


b)

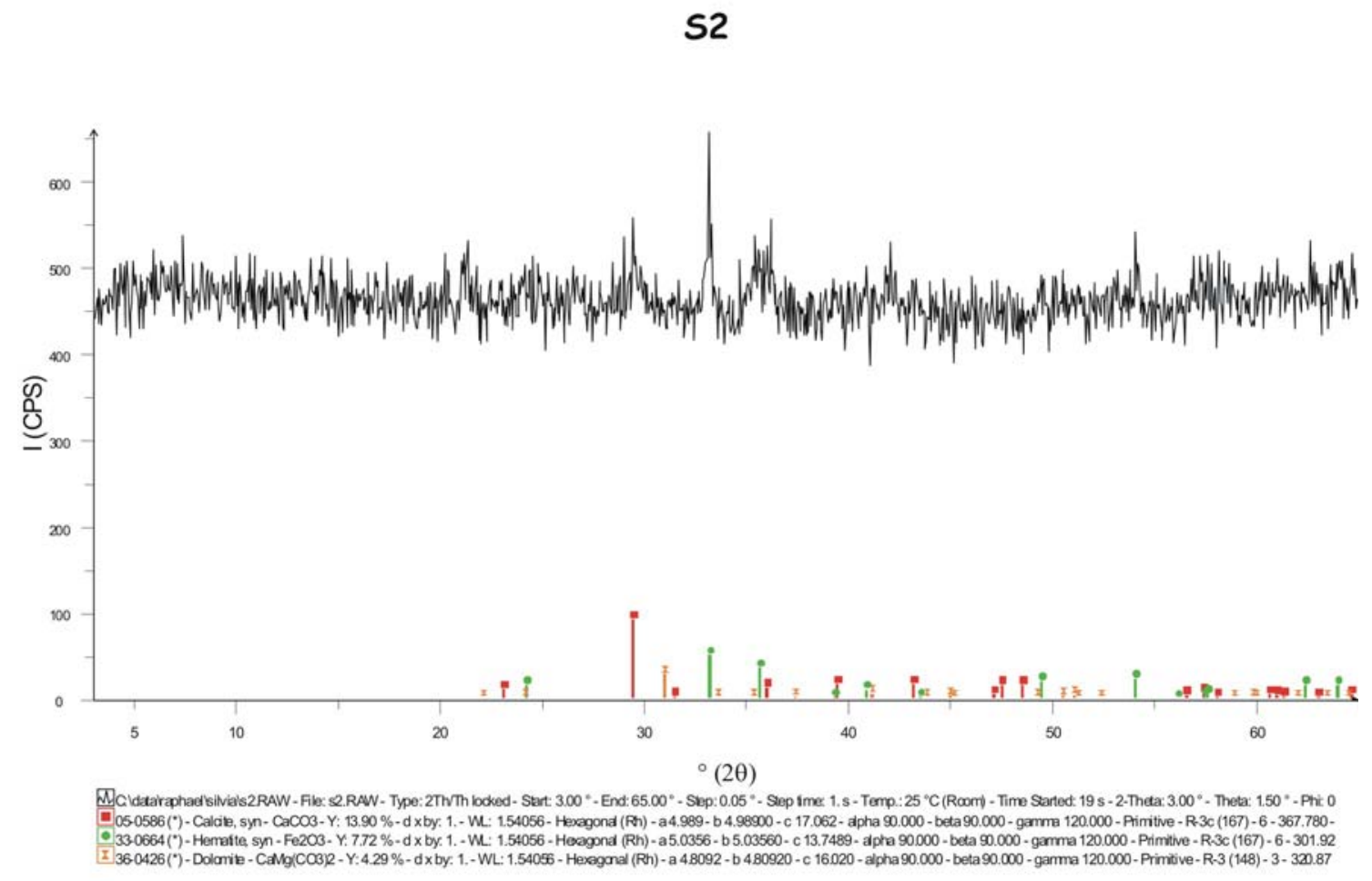

c)

S3

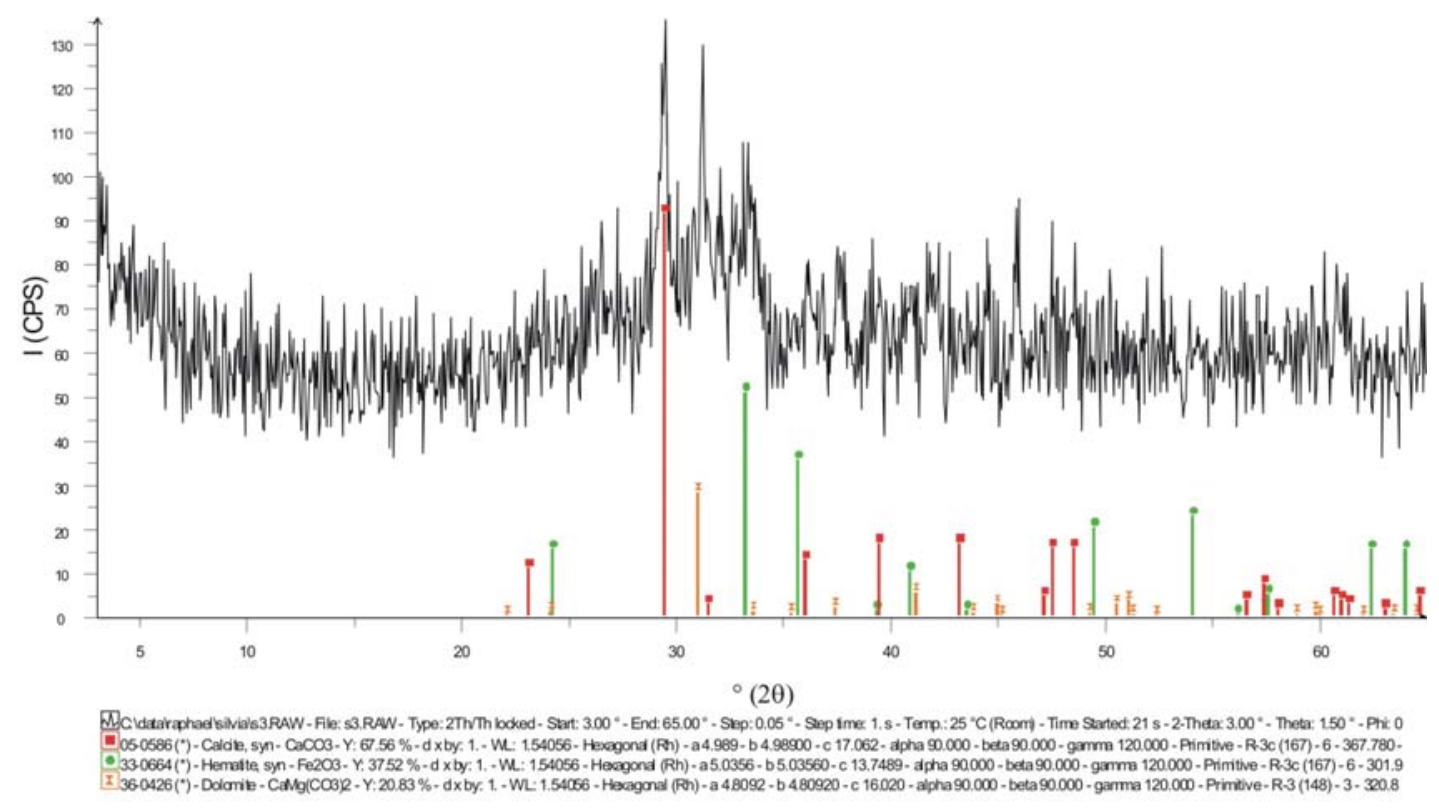


d)

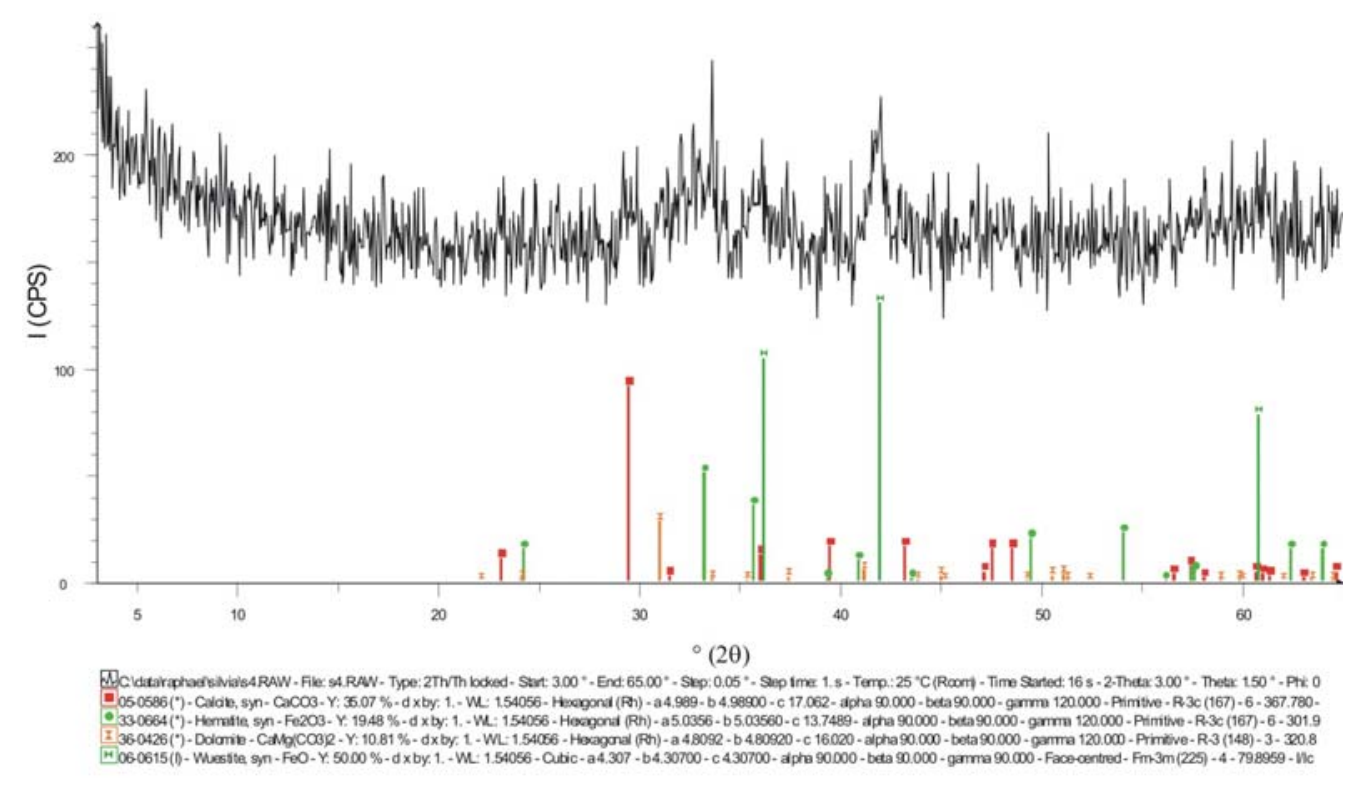

Figura 7.4-6. a, b, c, d: Difratogramas das amostras de solos/sedimentos associados aos poços de monitoramento (PM1 a PM4) na área do Aterro.

As amostras de solos/sedimentos são constituídas por materiais complexos, uma vez que se trata de resíduos provenientes dos diferentes processos de fabricação do aço, descartados na área desde o inicio das atividades, juntamente com os sedimentos do manguezal presente na área de instalação da indústria.

Desta forma, os dados difratométricos, em todas as amostras, indicaram presença de hematita e minerais carbonáticos, também detectados nas amostras dos resíduos dispostos na área; mais presença de argilominerais como a caulinita, também detectada nas amostras de sedimentos da margem do Rio Piaçaguera.

\subsection{Capacidade de Troca Catiônica}

As partículas de solo, devido suas dimensões, são consideradas como colóides, apresentam-se carregadas com cargas positivas ou negativas. Nas 
superfícies das partículas ou em porções quebradas encontram-se, geralmente cargas negativas. Outra possibilidade para que uma partícula se apresente carregada negativamente refere-se ao resíduo de carga do oxigênio.

O número de átomos de oxigênio nas estruturas das argilas silicáticas é sempre maior que dos outros elementos que compõem o edifício cristalino das argilas silicáticas e a quebra dos minerais de argila expõem principalmente seus átomos disponibilizando uma de suas valências (Hypolito, 2007).

Existem na superfície dos argilominerais sítios de adsorção livres que podem se ligar às partículas neutras que ao se aproximarem de sítios livres de adorção sofrem polarização e ligarem-se as partículas coloidais por forças de van der Waals e por pontes de hidrogênio.

Desta forma, os solos possuem a capacidade de adsorver cátions e mantêm um equilíbrio dinâmico de permuta desses cátions com outros presentes na solução do solo. Tal propriedade é denominada capacidade de troca catiônica (CTC).

A CTC do solo é um dos mais importantes indicadores da capacidade de retenção de metais pesados em sua na fase sólida (Deutsch, 1997).

As análises de CTC foram realizadas na Escola Superior de Agricultura Luiz de Queirós (Tabela 7.5-1).

Tabela 7.5-1: Resultados de CTC e de matéria orgânica dos sedimentos da margem do Rio Piaçaguera

\begin{tabular}{l|c|c}
\hline Amostra & CTC (cmolc kg & Matéria Orgânica $\left(\mathbf{g ~ d m}^{-3}\right)$ \\
\hline Sd1 & 166,00 & 40,00 \\
\hline Sd2 & 240,00 & 32,00 \\
\hline
\end{tabular}

As análises apresentaram teores de CTC elevados, significando capacidade de troca de cátions também elevada. No entanto, devido ao fato da área localizarse em região de manguezal, deve-se considerar a influência do sódio (acumulado e/ou depositado) no complexo trocável do solo/sedimento, sem relação direta com as argilas. 


\subsection{FLUORESCÊNCIA DE RAIOS $\mathbf{X}$}

Para caracterização da composição química total dos materiais estudados foram realizadas análises químicas por Fluorescência de Raios X no Laboratório do GMC/IGc-USP.

Foram analisados os minérios de ferro (Mi), carvão mineral $(\mathrm{CM})$, coque $(\mathrm{CQ})$ matérias primas na fabricação do aço. Analisaram-se também subprodutos gerados na fabricação do aço como escória (ES), material depositado na célula do Aterro (R1), lodo (LD) associado ao efluente do Aterro, amostras de pilhas de resíduos (R2 e R3), solos/sedimentos ( $\mathrm{S} 1$ a $\mathrm{S} 4$ ) associados aos poços de monitoramento instalados na área e amostras de sedimentos (Sd1 e Sd2) da margem do Rio Piaçaguera.

As análises químicas dos constituintes maiores e traços acham-se apresentadas na Tabela 7.6-1. (a, b, c).

Tabela 7.6-1.a.: Análises químicas dos constituintes maiores e menores das amostras de matérias primas utilizadas na fabricação do aço.

\begin{tabular}{|c|c|c|c|}
\hline Parâmetros & CM & $\mathbf{C Q}$ & Mi \\
\hline \multicolumn{4}{|c|}{ Elementos Maiores (\%) } \\
\hline $\mathrm{SiO}_{2}$ & 31,44 & 0,03 & 1,34 \\
\hline $\mathrm{Al}_{2} \mathrm{O}_{3}$ & 15,51 & 0,01 & 0,98 \\
\hline $\mathrm{MgO}$ & 2,11 & nd & 0,06 \\
\hline $\mathrm{CaO}$ & 1,96 & 0,02 & 0,06 \\
\hline $\mathrm{Na}_{2} \mathrm{O}$ & 1,30 & nd & 0,07 \\
\hline $\mathrm{K}_{2} \mathrm{O}$ & 2,11 & nd & 0,10 \\
\hline $\mathrm{P}_{2} \mathrm{O}_{5}$ & 0,78 & nd & 0,01 \\
\hline $\mathrm{Fe}_{2} \mathrm{O}_{3}$ & 9,47 & 0,02 & 95,38 \\
\hline MnO & 0,42 & nd & 0,01 \\
\hline \multicolumn{4}{|c|}{$\operatorname{Traços~}\left(\mathrm{mg} \mathrm{kg}^{-1}\right)$} \\
\hline $\mathrm{Cu}$ & 46,00 & 13,00 & nd \\
\hline $\mathbf{P b}$ & 46,00 & 14,00 & 70,00 \\
\hline $\mathbf{Z n}$ & 31,00 & 18,00 & 31,00 \\
\hline $\mathbf{s}$ & 3590,00 & 7960,00 & 130,00 \\
\hline
\end{tabular}


Tabela 7.6.-1.b.: Análises químicas das amostras de resíduos gerados na fabricação do aço.

\begin{tabular}{|c|c|c|c|c|c|c|c|c|c|}
\hline Parâmetros & ES & LD & $\mathbf{R} 1$ & R2a & $R 2 b$ & R2c & R3a & R3b & R3c \\
\hline \multicolumn{10}{|c|}{ Elementos Maiores (\%) } \\
\hline $\mathrm{SiO}_{2}$ & 33,58 & 31,21 & 5,06 & 1,81 & 1,37 & 1,69 & 13,02 & 13,17 & 12,57 \\
\hline $\mathrm{Al}_{2} \mathrm{O}_{3}$ & 12,81 & 16,67 & 1,44 & 0,36 & 0,38 & 0,40 & 5,72 & 4,98 & 4,32 \\
\hline MgO & 6,61 & 1,32 & 1,19 & nd & nd & nd & 10,77 & 11,05 & 9,77 \\
\hline $\mathrm{CaO}$ & 40,58 & 1,32 & 6,15 & 0,07 & 0,06 & 0,10 & 33,36 & 34,65 & 33,91 \\
\hline $\mathrm{Na}_{2} \mathrm{O}$ & 0,27 & 0,42 & 0,15 & $\mathrm{nd}$ & $\mathrm{nd}$ & $\mathrm{nd}$ & nd & 0,02 & nd \\
\hline $\mathrm{K}_{2} \mathrm{O}$ & 0,46 & 0,60 & 0,18 & nd & nd & 0,01 & 0,04 & 0,04 & 0,02 \\
\hline $\mathrm{P}_{2} \mathrm{O}_{5}$ & 0,02 & 0,28 & 0,12 & 1,30 & 1,30 & 1,34 & 0,96 & 1,00 & 1,06 \\
\hline $\mathrm{Fe}_{2} \mathrm{O}_{3}$ & 0,55 & 47,99 & 61,62 & 91,45 & 91,55 & 91,61 & 26,57 & 26,73 & 31,85 \\
\hline $\mathrm{MnO}$ & 0,67 & 0,40 & 1,22 & 0,45 & 0,44 & 0,46 & 4,51 & 4,98 & 4,76 \\
\hline \multicolumn{10}{|c|}{ Traços $\left(\mathrm{mg} \mathrm{kg}^{-1}\right)$} \\
\hline $\mathrm{Cu}$ & 525,00 & 100,00 & 45,00 & 226,00 & 236,00 & 223,00 & 15,00 & 20,00 & 20,00 \\
\hline $\mathbf{P b}$ & 5,00 & 197,00 & 909,00 & 18,00 & 23,00 & 22,00 & 10,00 & 9,00 & 7,00 \\
\hline $\mathbf{S}$ & 8425,00 & 22616,00 & 8917,00 & 1403,00 & 1389,00 & 1358,00 & 2538,00 & 2559,00 & 1709,00 \\
\hline $\mathrm{Zn}$ & 7,00 & 253,00 & 4975,00 & 237,00 & 256,00 & 272,00 & 28,00 & 9,00 & 24,00 \\
\hline
\end{tabular}

Tabela 7.6-1.c.: Análises químicas das amostras de solos/sedimentos associados aos poços de monitoramento (S1 a S4) e sedimentos da margem do Rio Piaçaguera (Sd1 e $\mathrm{Sd} 2)$

\begin{tabular}{l|c|c|c|c|c|c}
\hline Parâmetros & S1 & S2 & S3 & S4 & Sd1 & Sd2 \\
\hline \multicolumn{7}{|c|}{ Elementos Maiores (\%) } \\
\hline $\mathbf{S i O}_{\mathbf{2}}$ & 29,21 & 6,69 & 27,12 & 12,70 & 49,35 & 18,54 \\
\hline $\mathbf{A l}_{\mathbf{2}} \mathbf{O}_{3}$ & 4,64 & 1,07 & 9,33 & 4,69 & 13,43 & 5,47 \\
\hline $\mathbf{M n O}$ & 2,11 & 0,89 & 1,86 & 5,22 & 0,15 & 4,13 \\
\hline $\mathbf{M g O}$ & 3,35 & 0,64 & 7,48 & 8,46 & 1,44 & 6,12 \\
\hline $\mathbf{C a O}$ & 13,88 & 4,23 & 40,85 & 33,80 & 6,60 & 28,68 \\
\hline $\mathbf{N a}_{\mathbf{2}} \mathbf{O}$ & 0,02 & 0,03 & 0,02 & 0,00 & 0,63 & 0,20 \\
\hline $\mathbf{K}_{\mathbf{2}} \mathbf{O}$ & 0,61 & 0,10 & 0,39 & 0,02 & 2,15 & 0,56 \\
\hline $\mathbf{P}_{\mathbf{2}} \mathbf{O}_{\mathbf{5}}$ & 0,44 & 0,16 & 0,33 & 1,10 & 0,61 & 1,29 \\
\hline $\mathbf{F e}_{\mathbf{2}} \mathbf{O}_{\mathbf{3}}$ & 26,09 & 67,17 & 7,76 & 28,68 & 7,40 & 23,04 \\
\hline $\mathbf{C u}$ & 31,00 & 45,00 & 11,00 & 18,00 & 13,00 & 77,00 \\
\hline $\mathbf{P b}$ & 75,00 & 429,00 & 10,00 & 7,00 & 26,00 & 51,00 \\
\hline $\mathbf{S}$ & 740,00 & 1690,00 & 1660,00 & 1540,00 & 2150,00 & 3910,00 \\
\hline $\mathbf{Z n}$ & 115,00 & 6764,00 & 19,00 & 24,00 & 66,00 & 372,00 \\
\hline
\end{tabular}

Os resultados analíticos dos íons metálicos das amostras sólidas, apresentam concentrações consideráveis dos íons poluente como ferro, manganês, cobre, chumbo e zinco. O minério de ferro utilizado pela empresa apresenta porcentagem de 95,38\% como $\mathrm{Fe}_{2} \mathrm{O}_{3}$. 
Outros insumos utilizados no processo siderúrgico, como coque e calcário, resultam em subprodutos que são, diariamente descartados no Aterro. A variedade da origem desses materiais explicam os valores dispersos dos constituintes das amostras sólidas.

As amostras coletadas nas pilhas de resíduos indicam maior mobilidade dos íons poluentes na pilha de resíduo $\mathrm{R} 2$, composta de material de granulação fina e mais uniforme. Estas características mantêm limitada a difusão de oxigênio do ar atmosférico apresentando, como conseqüência, pequenas alterações químicas no material do topo, mais exposto aos agentes do intemperísmo, proporcionando condições de $\mathrm{pH}$ e Eh tais que os íons se mobilizam, apesar de fazerem parte de compostos muito estáveis.

O material depositado na pilha de resíduo R3, de granulação grosseira, apresenta maior número de poros e aumento da difusão de oxigênio no seu interior; desta forma a distribuição homogênea de oxigênio resultou em valores analíticos praticamente constantes dos íons de interesse neste trabalho ao longo de toda a pilha.

As amostras de solos/sedimentos associadas aos poços de monitoramento (PM1 a PM4) juntamente com a de sedimentos da margem do Rio Piaçaguera, apresentam teores elevados dos íons metálicos poluentes o que pode ser considerado fonte potencial destes elementos para as águas superficiais e subterrâneas da área de estudo. 


\subsection{EXTRAÇÕES lôNICAS}

\subsection{1. Ácido Nítrico}

A Extração Total em solos, de modo geral, refere-se ao tratamento de amostras que possibilita a compreensão da disponibilidade dos íons metálicos associados às partículas sólidas. Para extrações são utilizados ácidos como clorídrico, nítrico e acético, havendo divergências de uso quanto a natureza desses ácidos, suas concentrações e tempo de ataque.

Sposito et al. (1982) testaram como agente extrator $\mathrm{HNO}_{3} 2 \mathrm{M} \mathrm{e} 4 \mathrm{M}$ à $80^{\circ} \mathrm{C}$ dissolvendo sulfetos de cádmio, níquel, chumbo, zinco e, parcialmente, de cobre.

Beckett (1989) em estudos específicos sobre extratores aplicados em constituintes do solo utilizou ácido nítrico $1 \mathrm{M}$ para dissolver sulfetos.

O HCl geralmente é utilizado em concentração $0,1 \mathrm{M}$ para extração dos cátions adsorvidos, sendo capaz de deslocar cádmio, cobalto e zinco associados aos óxidos de ferro e manganês, carbonatos e matéria orgânica. Em concentração 0,5 M dissolve óxidos e compostos orgânicos de cobre e parcialmente sulfeto de cobre (Luomma \& Jenne apud Becket, 1989).

Um outro método de Extração Total refere-se ao ataque com reagentes: dietilenodiaminopentacético (EDPA), dietilenodiaminotetracético (EDTA) e EDTA/NH ${ }_{4} \mathrm{Ac}$, formando complexos estáveis com a maioria dos metais pesados (Ure et al., 1993 e Quevauviller et al., 1997).

A COMMUNITY BUREAU OF REFERENCE (BCR) indica como método padrão de extração total de íons metálicos HAc 0,43 M (Ure et al., 1992).

Marques (2004) desenvolveu metodologia para extração total dos íons metálicos chumbo, zinco e cobre em meio nítrico $(8 \mathrm{M})$.

Neste trabalho foi utilizado para estudos da disponibilidade dos íons metálicos poluentes dispostos na área do Aterro, solos/sedimentos associados aos poços de monitoramento e sedimentos da margem do Rio Piaçaguera. 
Os resultados da extração nítrica (8M) dos materiais sólidos encontram-se nas Tabelas 7.7.1-1.(a b)

Tabela 7.7.1.-1.a.: Extração seletiva das amostras de resíduos descartados na área do Aterro Industrial, utilizando ácido nítrico (8M)

\begin{tabular}{|c|c|c|c|}
\hline Amostras/Parâmetros & $\begin{array}{c}F e_{t} \\
\left(m g d^{-3}\right)\end{array}$ & $\begin{array}{c}\mathrm{Mn}^{2+} \\
\left(\mathrm{mg} \mathrm{dm}^{-3}\right)\end{array}$ & $\begin{array}{c}\mathrm{Pb}^{2+} \\
\left(\mathrm{mg} \mathrm{dm}^{-3}\right)\end{array}$ \\
\hline Limite de deteç̧ão & 0,016 & 0,070 & 0,011 \\
\hline ES & 839,38 & 77,42 & nd \\
\hline$\overline{\text { LD }}$ & 1598,34 & 56,14 & 18,98 \\
\hline R1 & 0,09 & 0,02 & 2,40 \\
\hline$\overline{\mathbf{R} 2 \mathbf{a}}$ & 918,54 & 22,38 & 16,48 \\
\hline $\mathbf{R} 2 \mathbf{b}$ & 1018,69 & 19,23 & 7,86 \\
\hline R2c & 844,78 & 18,93 & 14,16 \\
\hline R3a & 1661,09 & 234,60 & nd \\
\hline R3b & 1734,52 & 277,19 & 0,21 \\
\hline R3c & 1811,01 & 239,63 & nd \\
\hline
\end{tabular}

nd: não detectado

Tabela 7.7.1.-1.b.: Extração seletiva das amostras de solos/sedimentos (S1 a S4) associados aos poços de monitoramento e sedimentos da margem do Rio Piaçaguera (Sd1 e Sd2)l, utilizando ácido nítrico (8M)

\begin{tabular}{|c|c|c|c|}
\hline Amostras & $\begin{array}{c}\mathrm{Fe}_{\mathrm{t}} \\
\left(\mathrm{mg} \mathrm{dm}^{-3}\right)\end{array}$ & $\begin{array}{c}\mathrm{Mn}^{2+} \\
\left(\mathrm{mg} \mathrm{dm}^{-3}\right)\end{array}$ & $\begin{array}{c}\mathrm{Pb}^{2+} \\
\left(\mathrm{mg} \mathrm{dm}^{-3}\right)\end{array}$ \\
\hline Limite de detecção & 0,016 & 0,070 & 0,011 \\
\hline S1 & 1124,14 & 122,79 & nd \\
\hline $\mathbf{S 2}$ & 3706,98 & 71,03 & 3,38 \\
\hline S3 & 640,97 & 20,54 & nd \\
\hline $\mathbf{S 4}$ & 1889,26 & 372,05 & nd \\
\hline Sd1 & 622,39 & 26,07 & nd \\
\hline$\overline{S d 2}$ & 663,83 & 2,64 & nd \\
\hline
\end{tabular}

nd: não detectado

A disponibilidade dos íons de metais pesados presentes nos resíduos depositados na área do aterro em ordem decrescente foi ferro, manganês e chumbo $(\mathrm{Fe}>>\mathrm{Mn}>\mathrm{Pb})$. Estes metais apresentam diferentes comportamentos geoquímicos, favorecendo retenções e/ou liberação da fase sólida. A heterogeneidade dos resíduos também é responsável pela maior ou menor 
liberação dos íons metálicos; a Figura 7.7.1-1 ilustra a heterogeneidade dos resíduos analisados.

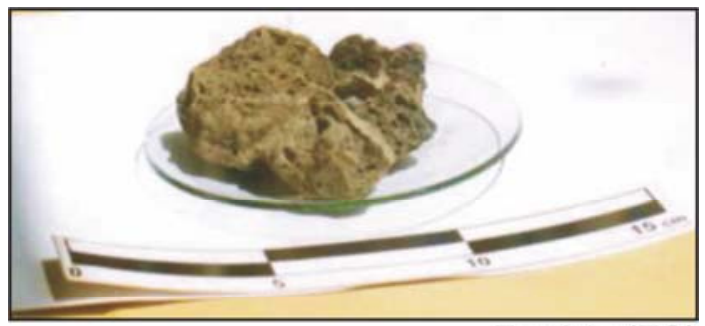

Escória (ES)
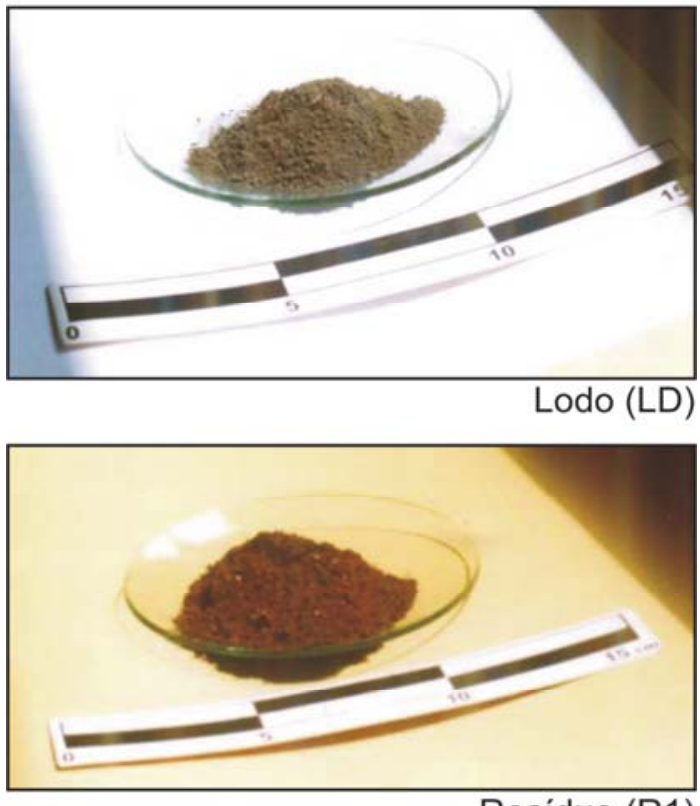

Resíduo (R1)

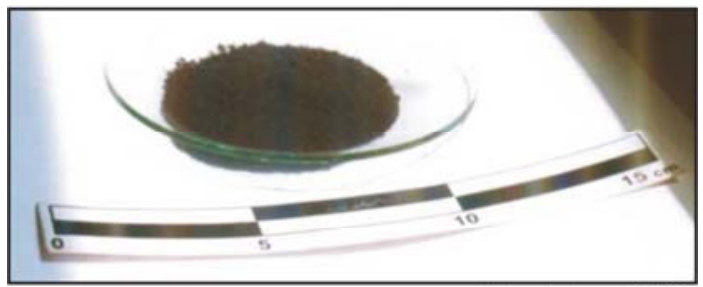

Resíduo (R2)

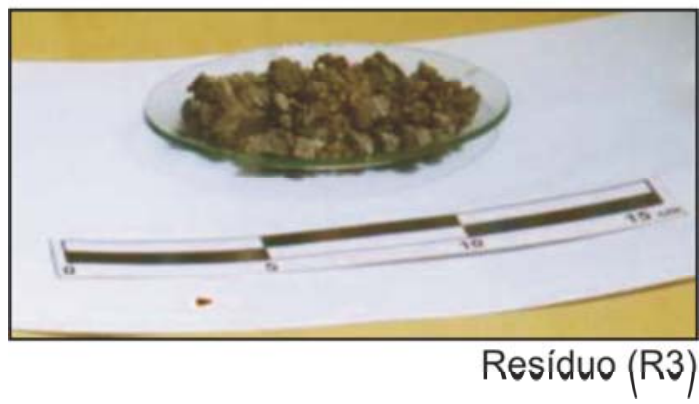

Figura 7.7.1-1: Amostras de resíduos descartados na área do Aterro 
Os materiais dispostos em pilhas apresentam partículas distribuídas heterogeneamente variando desde frações argilosas, como a amostra da pilha de resíduos $\mathrm{R} 2$ composta por lama de aciaria, até pequenos blocos formados por escórias como a amostra R3.

Esta heterogeneidade é resultado de alteração seletiva que ocorre na pilha desde o topo até a base, sujeita ao mecanismo de oferta de oxigênio e taxa de geração de ácidos como o sulfúrico.

A elevada quantidade de ferro e enxofre nestes resíduos leva a formação de sulfetos muito estáveis como o de ferro e chumbo.

O sistema formado principalmente por ferro e sulfetos sofre processo de óxido-redução e hidrólise que podem ser representados pelas equações químicas:

$$
\begin{gathered}
2 \mathrm{FeS}_{2}(\mathrm{~s})+7 \mathrm{O}_{2}(\mathrm{~g})+2 \mathrm{H}_{2} \mathrm{O}(\mathrm{l}) \stackrel{\leftarrow}{\leftrightarrows} 2 \mathrm{Fe}^{2+}(\mathrm{aq})+4 \mathrm{SO}_{4}{ }^{2-}(\mathrm{aq})+4 \mathrm{H}^{+}(\mathrm{g}) \\
2 \mathrm{Fe}^{2+}(\mathrm{aq})+\mathrm{O}_{2}(\mathrm{~g})+4 \mathrm{H}^{+}(\mathrm{aq}) \stackrel{\leftrightarrows}{\leftrightarrows} 4 \mathrm{Fe}^{3+}(\mathrm{s})+2 \mathrm{H}_{2} \mathrm{O}(\mathrm{l}) \\
4 \mathrm{Fe}^{3+}(\mathrm{s})+12 \mathrm{H}_{2} \mathrm{O}(\mathrm{l})+4 \mathrm{H}^{+}(\mathrm{g}) \stackrel{\leftrightarrows}{\leftrightarrows} 4 \mathrm{Fe}(\mathrm{OH})_{3}(\mathrm{~s})+16 \mathrm{H}^{+}(\mathrm{g}) \\
\mathrm{FeS}_{2}(\mathrm{~s})+14 \mathrm{Fe}^{3+}(\mathrm{s})+8 \mathrm{H}_{2} \mathrm{O}(\mathrm{l}) \leftrightarrows 15 \mathrm{Fe}^{2+}(\mathrm{aq})+2 \mathrm{SO}_{4}{ }^{2-}(\mathrm{aq})+16 \mathrm{H}^{+}(\mathrm{g})
\end{gathered}
$$

O oxigênio, além de oxidar o sulfeto, gerando sulfato e pode, dependendo das quantidades e do meio, oxidar o ferro metálico para ferro (III).

Por outro lado o sulfeto é um agente redutor que facilita a formação do $\mathrm{Fe}^{2+}$, que é a forma segundo a qual o ferro torna-se disponibilizado ao meio ambiente.

Como os íons ferro acham-se em grande quantidade o poder oxidante do oxigênio predomina em relação ao sulfeto.

Quanto à acidez têm-se dois fenômenos antagônicos, devido ao fenômeno de hidrólise: 


$$
\begin{gathered}
\mathrm{S}^{2-}(\mathrm{s})+\mathrm{H}_{2} \mathrm{O}(\mathrm{l}) \stackrel{\leftarrow}{\rightarrow} \mathrm{HS}^{-}(\mathrm{g})+\mathrm{OH}^{-}(\mathrm{aq}) \\
\mathrm{Fe}^{3+}(\mathrm{s})+\mathrm{H}_{2} \mathrm{O}(\mathrm{I}) \stackrel{\leftarrow}{\rightarrow} \mathrm{Fe}(\mathrm{OH})_{3}(\mathrm{~s})+\mathrm{H}^{+}(\mathrm{aq})
\end{gathered}
$$

Como se observa elevação de $\mathrm{pH}$ no meio, a reação de sulfetos com água sobrepuja a hidrólise do ferro (III).

$\mathrm{Na}$ pilha de resíduos $\mathrm{R} 2$, a presença de grãos finos dificulta a difusão do oxigênio e, conseqüentemente reduz a taxa de oxidação com liberação dos metais adsorvidos; já na pilha de resíduos $\mathrm{R} 3$, com maior permeabilidade, a taxa de difusão de oxigênio é elevada e, desta forma, a taxa dos sulfetos é bastante alta com as concentrações de sulfatos, $\mathrm{Fe}^{3+} \mathrm{e} \mathrm{H}^{+}$bastante elevados levando a dessorção dos íons metálicos.

A disponibilidade do manganês está relacionada às reações que envolvem oxidação de $\mathrm{Fe}^{2+}$ e $\mathrm{S}^{-}$, que estabilizam o manganês na sua forma mais solúvel (como manganês II), além disso, ocorre difusão das camadas superficiais das pilhas ao interior onde predominam condições anóxicas. Os óxidos de manganês sofrem redução segundo as reações:

$$
\begin{aligned}
& 2 \mathrm{Fe}^{2+}(\mathrm{aq})+\mathrm{MnO}_{2}(\mathrm{~s})+2 \mathrm{HCO}_{3}^{-}(\mathrm{aq})+2 \mathrm{H}_{2} \mathrm{O}(\mathrm{l}) \stackrel{\leftarrow}{\rightarrow} \mathrm{Fe}(\mathrm{OH})_{3}(\mathrm{~s})+\mathrm{Mn}^{2+}(\mathrm{aq})+2 \mathrm{CO}_{2} \\
& \mathrm{MnO}_{2}(\mathrm{~s})+\mathrm{H}_{2} \mathrm{~S}(\mathrm{~g})+\mathrm{H}_{2}(\mathrm{~g}) \stackrel{\leftarrow}{\leftrightarrows} \mathrm{Mn}^{2+}(\mathrm{aq})+\mathrm{S}^{0}(\mathrm{~s})+2 \mathrm{H}_{2} \mathrm{O}(\mathrm{I}) \\
& 3 \mathrm{MnO}_{2}(\mathrm{~s})+\mathrm{S}^{0}(\mathrm{~s})+4 \mathrm{H}^{+}(\mathrm{g}) \leftrightarrows \mathrm{SO}_{4}{ }^{2-}(\mathrm{aq})+3 \mathrm{Mn}^{2+}(\mathrm{aq})+2 \mathrm{H}_{2} \mathrm{O}(\mathrm{l})
\end{aligned}
$$

Outro fator que pode explicar a disponibilidade de manganês está no fato da forma $\mathrm{Mn}^{2+}$ ser estável em ampla faixa de condições de pH-Eh (Hypolito, 1980 ;Stumm \& Morgan, 1998).

Os teores totais de manganês indicam acúmulo deste elemento nas porções mais superficiais das pilhas, conseqüência de sua oxidação e precipitação sob a forma de oxihidróxidos de manganês. 
O chumbo encontra-se predominantemente na forma metálica, podendo encontrar-se também como sulfetos, óxidos etc. entretanto, a reação de água sobre as pilhas produz hidróxidos, carbonatos e mesmo $\mathrm{Pb}^{2+}$ que são formas mais estáveis que em solução.

Como já mencionado, se de um lado a hidrólise do $\mathrm{Fe}^{3+}$ diminui o $\mathrm{pH}$, a do $\mathrm{S}^{2-}$ em água produz $\mathrm{OH}^{-}$e assim, a dissolução, dos compostos de chumbo, dependerão dessas duas reações químicas:

$$
\begin{gathered}
\mathrm{PbCO}_{3}(\mathrm{~s})+\mathrm{H}^{+}(\mathrm{g}) \stackrel{\leftrightarrows}{\rightarrow} \mathrm{Pb}^{2+}(\mathrm{aq})+\mathrm{H}_{2} \mathrm{O}(\mathrm{l})+\mathrm{CO}_{2}(\mathrm{~g}) \\
\mathrm{PbS}(\mathrm{s})+2 \mathrm{H}^{+}(\mathrm{g}) \stackrel{\leftrightarrow}{\leftrightarrows} \mathrm{Pb}^{2+}(\mathrm{aq})+\mathrm{H}_{2} \mathrm{~S}(\mathrm{~g}) \\
\mathrm{Pb}(\mathrm{OH})_{2}(\mathrm{~s})+2 \mathrm{H}^{+}(\mathrm{g}) \stackrel{\leftarrow}{\rightarrow} \mathrm{Pb}^{2+}(\mathrm{aq})+2 \mathrm{H}_{2} \mathrm{O}(\mathrm{l})
\end{gathered}
$$

Os solos/sedimentos associados aos poços de monitoramento são compostos por sedimentos de manguezal associados às escórias. Elas foram utilizadas como material de aterro do manguezal para instalação da indústria, juntamente com os diversos tipos de resíduos descartados na área formando pilhas, que por intemperísmo, contribuíram para composição destes solos/sedimentos, haja vista os resultados das análises mineralógicas e de fluorescência de Raios $X$ destes materiais.

Da mesma forma que os resíduos depositados na área, nos solos/sedimentos os materiais também encontram-se sob a forma de elementos metálicos, provavelmente como ligas e, também terão sua disponibilidade em função da hidrólise do ferro e sulfeto. Esses cátions, dependendo do $\mathrm{pH}$ do meio, podem fixar-se sob a forma de oxihidróxidos e carbonatos ou disponibilizarem-se nas soluções .

Nas amostras de solos/sedimentos associados aos poços de monitoramento e de sedimentos da margem do Rio Piaçaguera os resultados da extração nítrica indicam os teores iônicos potencialmente disponíveis para o meio ambiente. $\mathrm{E}$, de modo semelhante ao observado nas amostras de resíduos depositados na área do 
aterro, verifica-se que a disponibilidade do ferro é muito maior que de manganês, que por sua vez é maior que do chumbo. É importante ressaltar que as amostras de solos/sedimentos também apresentam diferentes disponibilidades dos íons metálicos em função de características mineralógicas e dos resíduos associados a eles.

Os valores orientadores aqui utilizados (EPA, 2004 para áreas industriais) indicaram para a amostra de solo/sedimento associada ao poço de monitoramento PM-2 (S2) apresentou concentração de íons ferro superior ao valor estabelecido pela lista supra citada; as amostras de solos/sedimentos associadas aos poços de monitoramento PM-01 e PM-04, (S1 e S4, respectivamente), e a amostra de sedimento da margem do Rio Piaçaguera coletada a jusante do aterro (Sd2) apresentaram concentrações de íons manganês superiores à referida lista.

A análise conjunta da disponibilidade destes íons metálicos e sua solubilidade nas águas subterrâneas (Tabela 7.2.1-1.) observa-se que houve baixa solubilidade destes íons (Figuras 7.2.1 a, b, c, d, e), indica equilíbrio dos íons ferro, com suas formas insolúveis de oxihidróxido e sulfatos. Os íons manganês mostram sua estabilidade na forma iônica reduzida como manganês (II) e o chumbo, na forma do sal de chumbo aquoso.

\subsubsection{Extração com Extrator do Tipo Soxhlet}

O comportamento dos íons metálicos dos resíduos depositados na área do aterro foi também estudado, através de extrações com extrator do tipo sohxlet (Figura 7.7.2-1.). As lixiviações foram efetuadas com água saturada em $\mathrm{CO}_{2}$ a temperatura ao redor de $70^{\circ} \mathrm{C}$. 


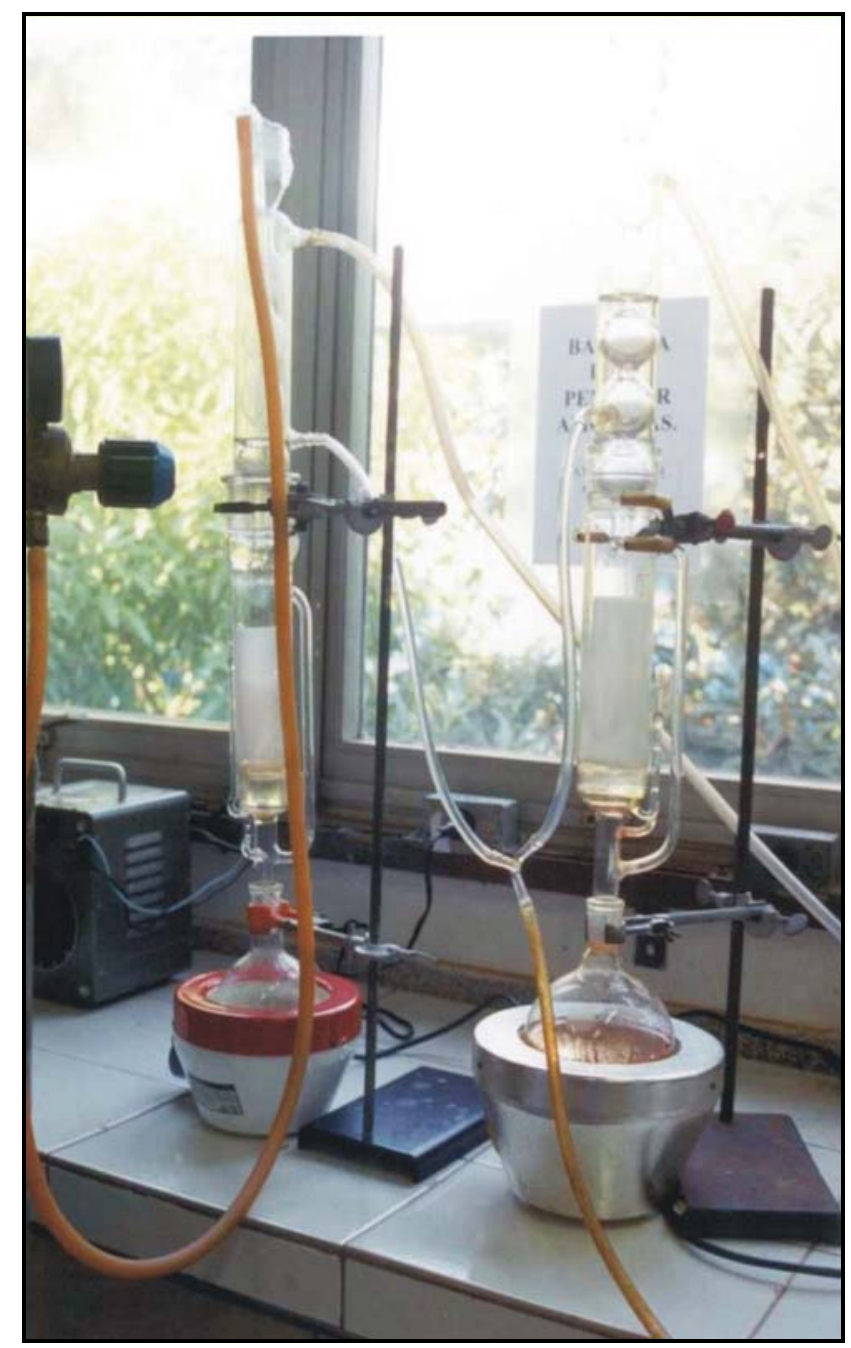

Figura 7.7.2-1: Extrator do tipo soxhlet utilizado nas lixiviações com $\mathrm{H}_{2} \mathrm{O} / \mathrm{CO}_{2}$ nas amostras de resíduos siderúrgicos

Utilizaram-se para os experimentos massas ao redor de $25 \mathrm{~g}$ de amostras de escória (ES), material depositado na célula do Aterro (R1) e resíduos depositados nas pilhas na área do Aterro, R2 e R3, (topo (a), meio (b) e base (c)). A temperatura do condensador do soxhlet foi mantida ao redor de $70^{\circ} \mathrm{C}$ e a taxa de fluxo de 24 gotas $\min ^{-1}$.

O volume de água destilada foi de $500 \mathrm{~mL}$ e o $\mathrm{pH}$ inicial de $5,48 \pm 0,1$.

A evolução dos experimentos foi acompanhada por análises de $\mathrm{Na}^{+}$e $\mathrm{K}^{+}$ (parâmetros escolhidos por serem de fácil controle analítico) em alíquotas de 25 $\mathrm{mL}$ coletadas diariamente; as extrações foram efetuadas até obtenção de valores constantes de desses íons 
c) Amostra do topo da pilha de resído R2 (a)- mi=25,2003g

\begin{tabular}{c|c|c|c}
\hline $\begin{array}{c}\text { parâmetros/ } \\
\text { duração }\end{array}$ & $\mathbf{K}^{+}$ & $\mathbf{N a}^{+}$ & $\mathbf{p H}$ \\
\hline $\mathbf{1}$ & 22,10 & 114,10 & 5,95 \\
\hline $\mathbf{2}$ & 22,60 & 118,00 & 6,20 \\
\hline $\mathbf{3}$ & 27,00 & 118,00 & 6,21 \\
\hline $\mathbf{4}$ & 38,64 & 228,40 & 7,28 \\
\hline $\mathbf{5}$ & 42,10 & 400,00 & 7,47 \\
\hline $\mathbf{6}$ & 43,80 & 424,50 & 7,52 \\
\hline $\mathbf{7}$ & 68,50 & 626,50 & 8,60 \\
\hline $\mathbf{8}$ & 80,00 & 630,00 & 8,60 \\
\hline $\mathbf{9}$ & 80,00 & 630,00 & 8,60 \\
\hline $\mathbf{1 0}$ & 80,00 & 630,00 & 8,60 \\
\hline \multicolumn{3}{|l}{}
\end{tabular}

d) Amostra do meio da pilha de resído $\mathrm{R} 2$ (b)- $\mathrm{mi}=25,0879 \mathrm{~g}$

\begin{tabular}{c|c|c|c}
$\begin{array}{c}\text { parâmetros/ } \\
\text { duração }\end{array}$ & $\mathbf{K}^{+}$ & $\mathbf{N a}^{+}$ & $\mathbf{p H}$ \\
\hline $\mathbf{1}$ & 111,10 & 114,10 & 6,07 \\
\hline $\mathbf{2}$ & 111,60 & 118,00 & 6,34 \\
\hline $\mathbf{3}$ & 317,00 & 218,00 & 6,42 \\
\hline $\mathbf{4}$ & 518,64 & 218,40 & 7,20 \\
\hline $\mathbf{5}$ & 722,10 & 320,00 & 8,76 \\
\hline $\mathbf{6}$ & 923,80 & 495,00 & 8,80 \\
\hline $\mathbf{7}$ & 1180,00 & 495,00 & 8,88 \\
\hline $\mathbf{8}$ & 1180,00 & 495,00 & 8,88 \\
\hline $\mathbf{9}$ & 1180,00 & 495,00 & 8,88 \\
\hline
\end{tabular}

e) Amostra da base da pilha de resído $\mathrm{R} 2$ (c)- $\mathrm{mi}=25,3003 \mathrm{~g}$ parâmetrosl

\begin{tabular}{c|c|c|c}
$\begin{array}{c}\text { parametros/ } \\
\text { duração }\end{array}$ & $\mathbf{K}^{+}$ & $\mathbf{N a}^{+}$ & $\mathbf{p H}$ \\
\hline $\mathbf{1}$ & 147,50 & 414,10 & 7,07 \\
\hline $\mathbf{2}$ & 162,80 & 518,00 & 7,34 \\
\hline $\mathbf{3}$ & 170,00 & 660,00 & 8,40 \\
\hline $\mathbf{4}$ & 230,00 & 660,00 & 8,76 \\
\hline $\mathbf{5}$ & 230,00 & 660,00 & 8,76 \\
\hline
\end{tabular}

f) Amostra do topo da pilha de resído R3 (a)- $\mathrm{mi}=25,0073 \mathrm{~g}$

\begin{tabular}{c|c|c|c}
\hline $\begin{array}{c}\text { parâmetros/ } \\
\text { duração }\end{array}$ & $\mathbf{K}^{+}$ & $\mathbf{N a}^{+}$ & $\mathbf{p H}$ \\
\hline $\mathbf{1}$ & 32,10 & 4,10 & 7,15 \\
\hline $\mathbf{2}$ & 32,60 & 8,00 & 7,34 \\
\hline $\mathbf{3}$ & 47,00 & 8,00 & 7,42 \\
\hline $\mathbf{4}$ & 48,64 & 8,40 & 7,50 \\
\hline $\mathbf{5}$ & 52,10 & 10,00 & 7,76 \\
\hline $\mathbf{6}$ & 53,80 & 12,50 & 7,80 \\
\hline $\mathbf{7}$ & 60,50 & 12,28 & 7,88 \\
\hline $\mathbf{8}$ & 60,78 & 13,50 & 7,88 \\
\hline $\mathbf{9}$ & 61,00 & 13,50 & 9,29 \\
\hline $\mathbf{1 0}$ & 61,00 & 13,78 & 9,29 \\
\hline $\mathbf{1 1}$ & 61,00 & 14,00 & 9,29 \\
\hline
\end{tabular}

g) Amostra do meio da pilha de resído $\mathrm{R} 3$ (b)- $\mathrm{mi}=25,0103 \mathrm{~g}$

\begin{tabular}{c|c|c|c}
\hline $\begin{array}{c}\text { parâmetros/ } \\
\text { duração }\end{array}$ & $\mathbf{K}^{+}$ & $\mathbf{N a}^{+}$ & $\mathbf{p H}$ \\
\hline $\mathbf{1}$ & 22,10 & 8,00 & 7,45 \\
\hline $\mathbf{2}$ & 22,60 & 8,00 & 7,48 \\
\hline $\mathbf{3}$ & 27,00 & 8,23 & 8,42 \\
\hline $\mathbf{4}$ & 28,64 & 9,15 & 9,20 \\
\hline $\mathbf{5}$ & 32,10 & 9,15 & 9,76 \\
\hline $\mathbf{6}$ & 33,80 & 9,88 & 9,80 \\
\hline $\mathbf{7}$ & 41,00 & 10,02 & 9,88 \\
\hline $\mathbf{8}$ & 41,00 & 10,25 & 9,88 \\
\hline $\mathbf{9}$ & 41,00 & 10,78 & 10,29 \\
\hline $\mathbf{1 0}$ & 41,00 & 11,40 & 10,29 \\
\hline
\end{tabular}


Nos primeiros litros de lixiviação as soluções mostraram-se com coloração levemente acastanhada e em seguida observou-se a presença de precipitado de cor branca avermelhada, este material foi identificado através de análises de Difratometria de Raios $X$ como sendo compostos homólogos a calcita com traços de óxidos de ferro.

Os valores de $\mathrm{pH}$ nas lixiviações com $\mathrm{H}_{2} \mathrm{O} / \mathrm{CO}_{2}$, nas amostras dos resíduos de escória, bem como do material depositado na célula do aterro (R1) e nas três regiões das pilhas variaram de forma semelhante, no entanto, na base, a hidrólise de sulfeto em quantidade bastante superior na base têm-se atenuação da concentração de $\mathrm{H}^{+}$com eliminação acentuada de hidroxila.

$$
\mathrm{S}^{2+}(\mathrm{aq})+\mathrm{H}_{2} \mathrm{O}(\mathrm{l}) \stackrel{\leftarrow}{\rightarrow} \mathrm{HS}^{-}(\mathrm{aq})+\mathrm{OH}^{-}(\mathrm{aq})
$$

Os teores de $\mathrm{Na}^{+}, \mathrm{K}^{+}\left(\mathrm{mg} \mathrm{dm}^{-3}\right)$ e $\mathrm{pH}$ dosados nas soluções lixiviadas, em função do volume diário, são fornecidos nas Tabelas 7.7.2-1.( a-h).

Tabelas 7.7.2-2 a, b, c, d, e, f, $\mathbf{g}, \mathbf{h}$ : Dados analíticos de sódio e potássio $\left(\mathrm{mg} \mathrm{dm}^{-3}\right)$ e pH das soluções obtidas por extração soxhlet das amostras de resíduos descartadas na área do Aterro.

a) Amostra de Escória (ES)- $\mathrm{mi}=25,300 \mathrm{~g}$

\begin{tabular}{c|c|c|c}
\multicolumn{4}{c}{ a) Amostra de Escória (ES)- $\mathbf{m i}=25,300 \mathrm{~g}$} \\
\hline $\begin{array}{c}\text { parâmetros/ } \\
\text { duração }\end{array}$ & $\mathbf{K}^{+}$ & $\mathbf{N a}^{+}$ & $\mathbf{p H}$ \\
\hline $\mathbf{1}$ & 11,10 & 14,10 & 6,07 \\
\hline $\mathbf{2}$ & 11,60 & 18,00 & 6,34 \\
\hline $\mathbf{3}$ & 18,64 & 18,40 & 6,42 \\
\hline $\mathbf{4}$ & 20,02 & 20,00 & 7,20 \\
\hline $\mathbf{5}$ & 22,10 & 24,50 & 8,76 \\
\hline $\mathbf{6}$ & 28,50 & 25,00 & 8,80 \\
\hline $\mathbf{7}$ & 28,50 & 26,00 & 8,88 \\
\hline $\mathbf{8}$ & 28,50 & 26,00 & 8,88 \\
\hline
\end{tabular}

b) Amostra da Célula do Aterro (R1)- mi= 25,0751g

\begin{tabular}{c|c|c|c}
\hline $\begin{array}{c}\text { parâmetros/ } \\
\text { duração }\end{array}$ & $\mathbf{K}^{+}$ & $\mathbf{N a}^{+}$ & $\mathbf{p H}$ \\
\hline $\mathbf{1}$ & 19,40 & 19,40 & 5,40 \\
\hline $\mathbf{2}$ & 46,00 & 46,00 & 7,00 \\
\hline $\mathbf{3}$ & 50,00 & 50,00 & 7,00 \\
\hline $\mathbf{4}$ & 50,50 & 50,50 & 13,50 \\
\hline $\mathbf{5}$ & 54,50 & 54,50 & 14,00 \\
\hline $\mathbf{6}$ & 60,60 & 60,60 & 14,00 \\
\hline $\mathbf{7}$ & 64,50 & 64,50 & 14,50 \\
\hline $\mathbf{8}$ & 64,50 & 64,50 & 16,00 \\
\hline $\mathbf{9}$ & 65,00 & 65,00 & 16,00 \\
\hline $\mathbf{1 0}$ & 65,00 & 65,00 & 16,00 \\
\hline
\end{tabular}


h) Amostra da base da pilha de resído R3(c)- mi= 25,3025g

\begin{tabular}{c|c|c|c}
\hline $\begin{array}{c}\text { parâmetros/ } \\
\text { duracão }\end{array}$ & $\mathrm{K}^{+}$ & $\mathrm{Na}^{+}$ & $\mathbf{p H}$ \\
\hline $\mathbf{1}$ & 12,10 & 5,28 & 8,20 \\
\hline $\mathbf{2}$ & 13,60 & 6,75 & 9,34 \\
\hline $\mathbf{3}$ & 27,00 & 7,95 & 9,42 \\
\hline $\mathbf{4}$ & 28,64 & 7,99 & 10,20 \\
\hline $\mathbf{5}$ & 42,10 & 7,99 & 10,76 \\
\hline $\mathbf{6}$ & 43,80 & 8,25 & 10,78 \\
\hline $\mathbf{7}$ & 60,50 & 8,84 & 10,78 \\
\hline $\mathbf{8}$ & 61,50 & 8,90 & 10,78 \\
\hline $\mathbf{9}$ & 61,80 & 8,98 & 10,79 \\
\hline $\mathbf{1 0}$ & 62,00 & 9,00 & 10,79 \\
\hline $\mathbf{1 1}$ & 62,00 & 9,93 & 10,79 \\
\hline $\mathbf{1 2}$ & 62,00 & 15,00 & 10,79 \\
\hline $\mathbf{1 3}$ & 62,00 & 15,20 & 10,79 \\
\hline
\end{tabular}

A projeção gráfica desses resultados encontram-se nas Figuras 7.7.2-2.(a, b) à 7.7.2-9 $(\mathrm{a}, \mathrm{b})$.
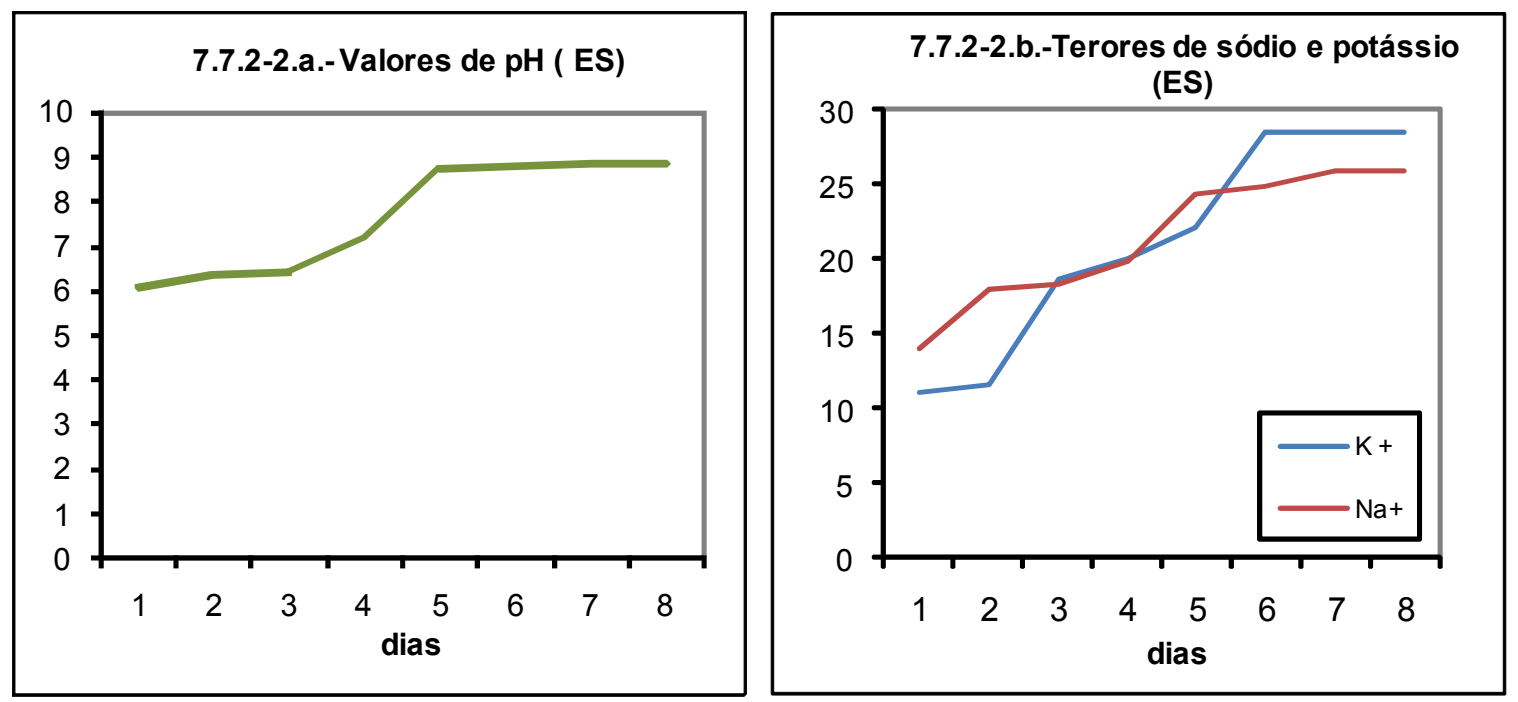

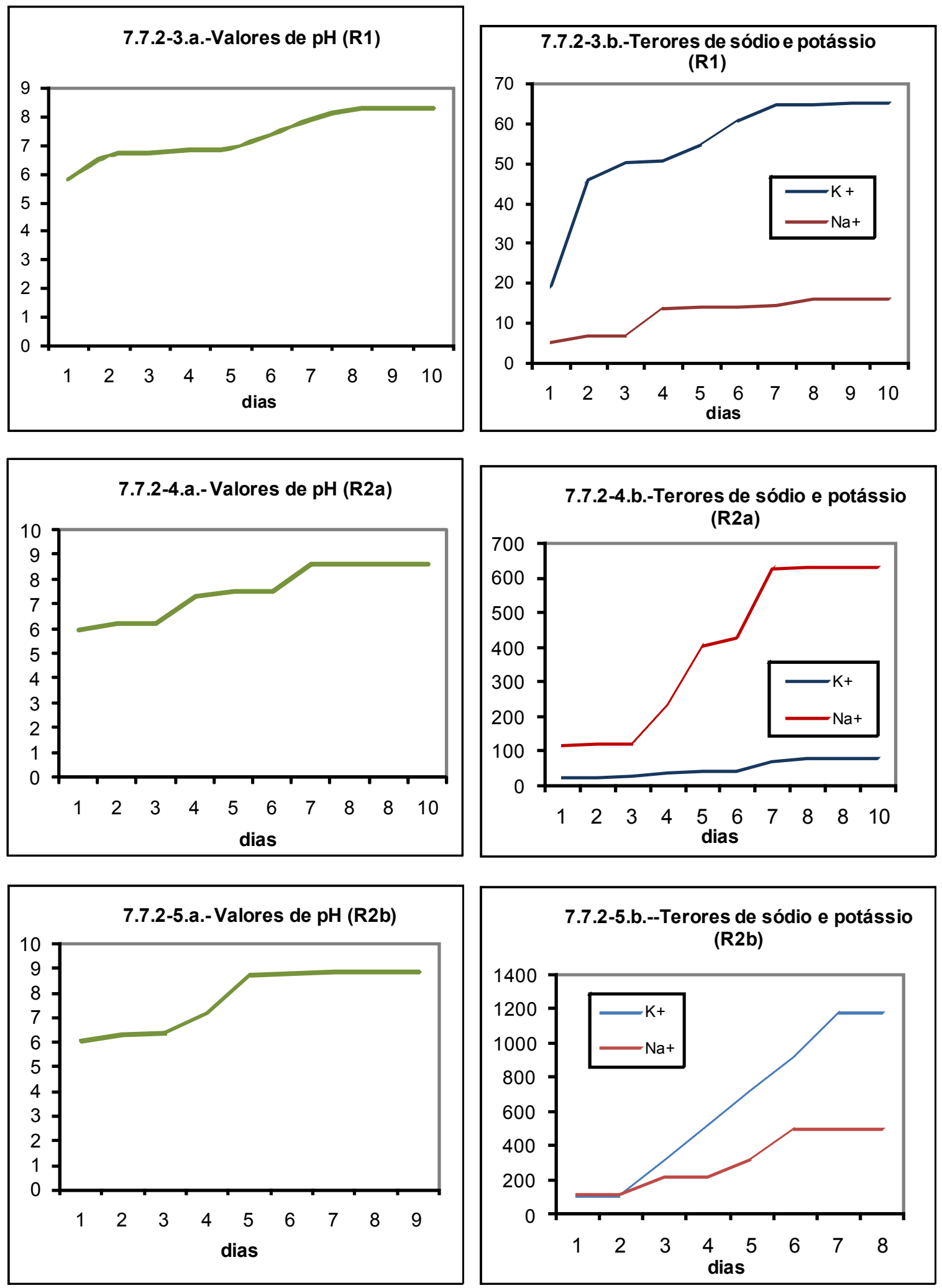

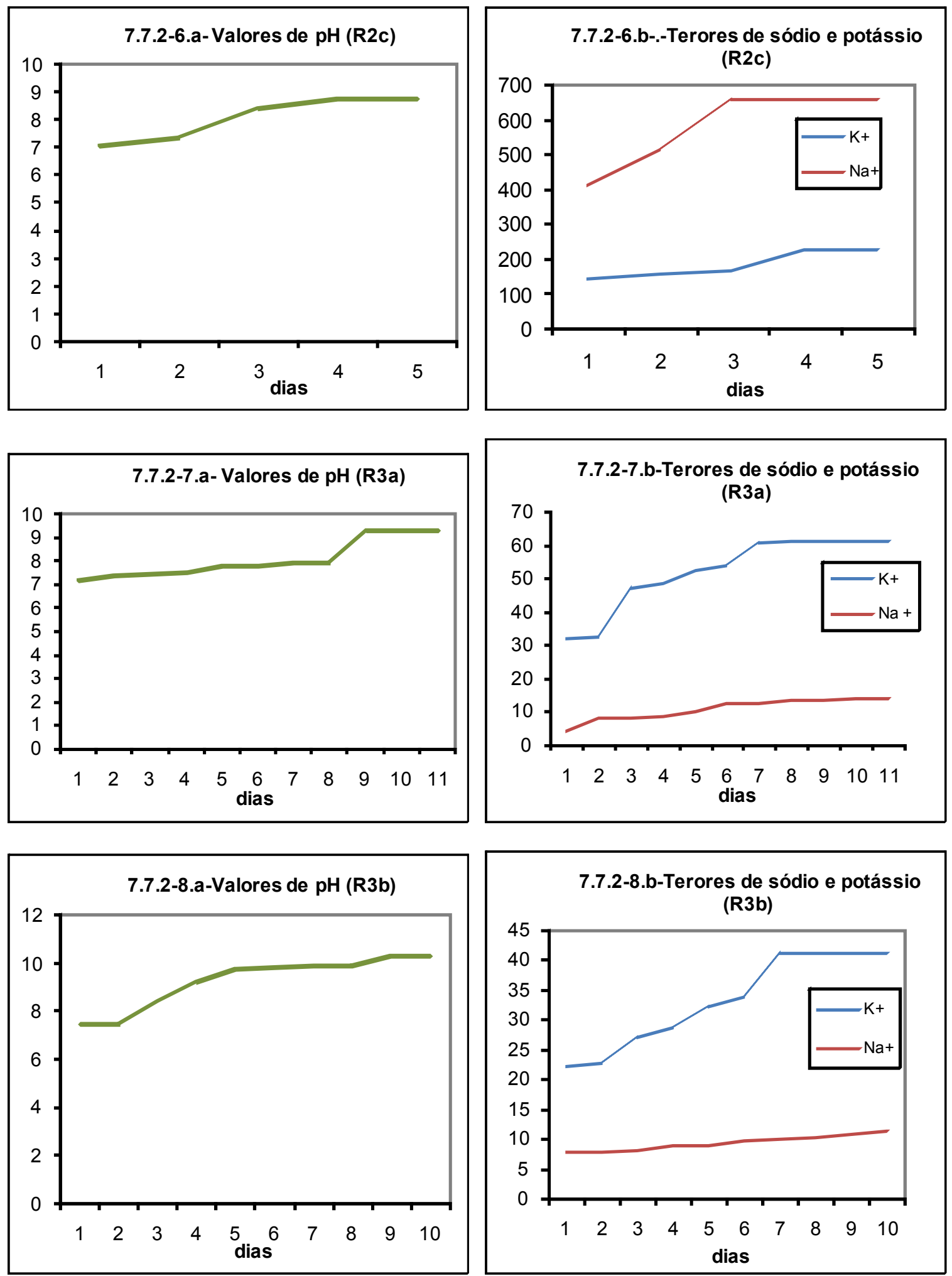

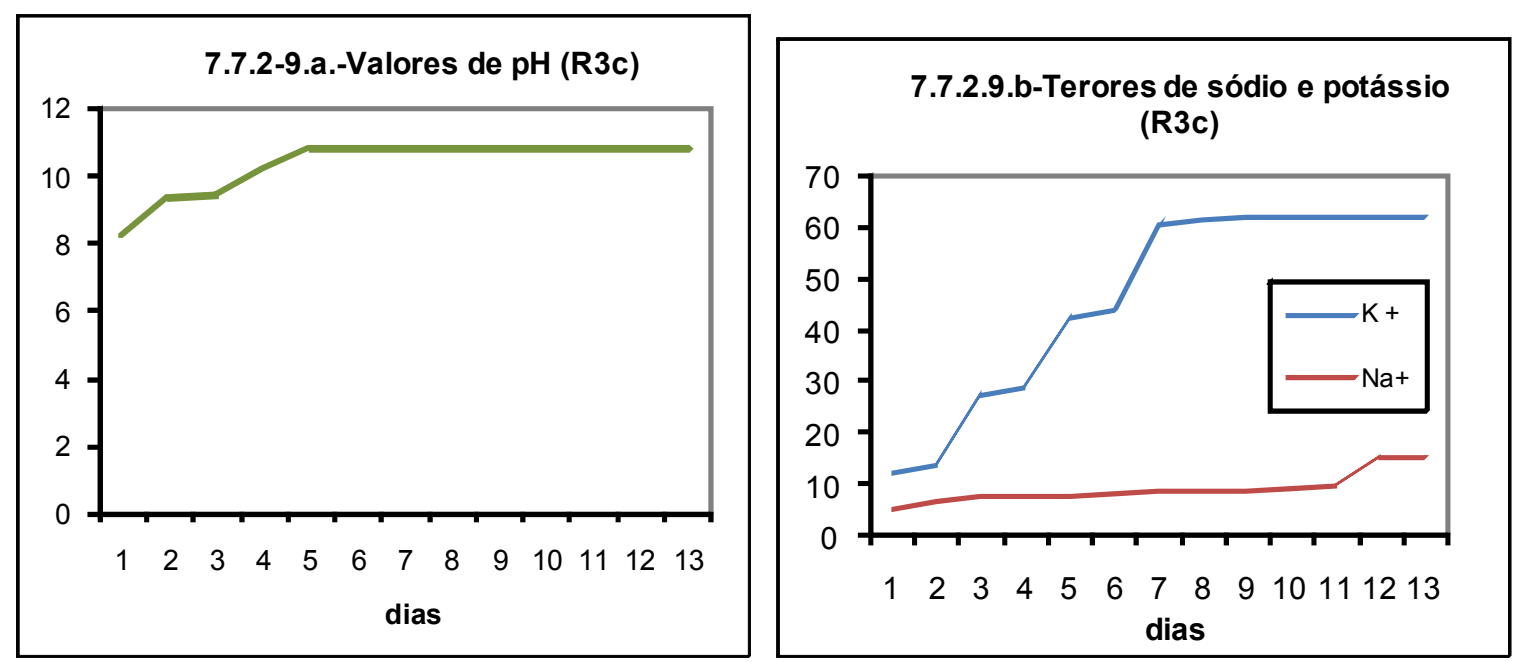

Figuras 7.7.2-2. (a, b) à 7.7.2-9. (a,b): Representação gráfica dos teores de sódio, potássio e pH das soluções obtidas pela lixiviação (soxhlet) das amostras de resíduos depositados na área do Aterro.

O sódio está relacionado aos sedimentos de origem marinha e acha-se associado a cloretos, sulfatos e carbonatos, formando sais muito solúveis. Sua concentração é afetada pela capacidade de adsorção deste elemento na superfície ativa dos colóides.

O potássio nas condições naturais é facilmente afetado por troca de bases e é adsorvido de forma pouco reversível pelas argilas em formação para fazer parte de sua estrutura, circunstância que o diferencia claramente do sódio. É por esse motivo, que nas águas naturais, apesar da abundância de potássio em muitas rochas, apresentam muito menos potássio que sódio, exceto em amostras muito diluídas (Custódio e Lhamas, 1986).

Nas soluções lixiviadas verifica-se, exceto nas amostras de resíduos R2 (meio e base), predomínio do íon potássio em relação ao sódio. Este comportamento se deve à elevada solubilidade dos íons sódio.

$\mathrm{Na}$ amostra de resíduo (R2) que apresenta fragmentos grosseiros de escória, as amostras do meio da pilha e da base, apresentaram comportamento semelhante ao da amostra de escória, com maior teor de íons sódio em relação ao potássio no lixiviado, em função da menor exposição aos agentes intempéricos. 
Devido à hidrólise de $\mathrm{S}^{2-}$, em quantidade bastante superior, tem-se atenuação da concentração de $\mathrm{H}^{+}$, os valores de $\mathrm{pH}$ das amostras lixiviadas apresentaram comportamento semelhantes aumentando no decorrer das lixiviações.

$$
\mathrm{S}^{2+}(\mathrm{aq})+\mathrm{H}_{2} \mathrm{O}(\mathrm{l}) \stackrel{\leftrightarrows}{\rightarrow} \mathrm{HS}^{-}(\mathrm{aq})+\mathrm{OH}^{-}(\mathrm{aq})
$$

Após a estabilização dos parâmetros mencionados acima as soluções foram analisadas por espectrofotometria de absorção atômica para detecção dos cátions e por cromatografia iônica para a detecção dos ânions; os resultados encontramse nas Tabelas 7.7.2-10 e 7.7.2-11 


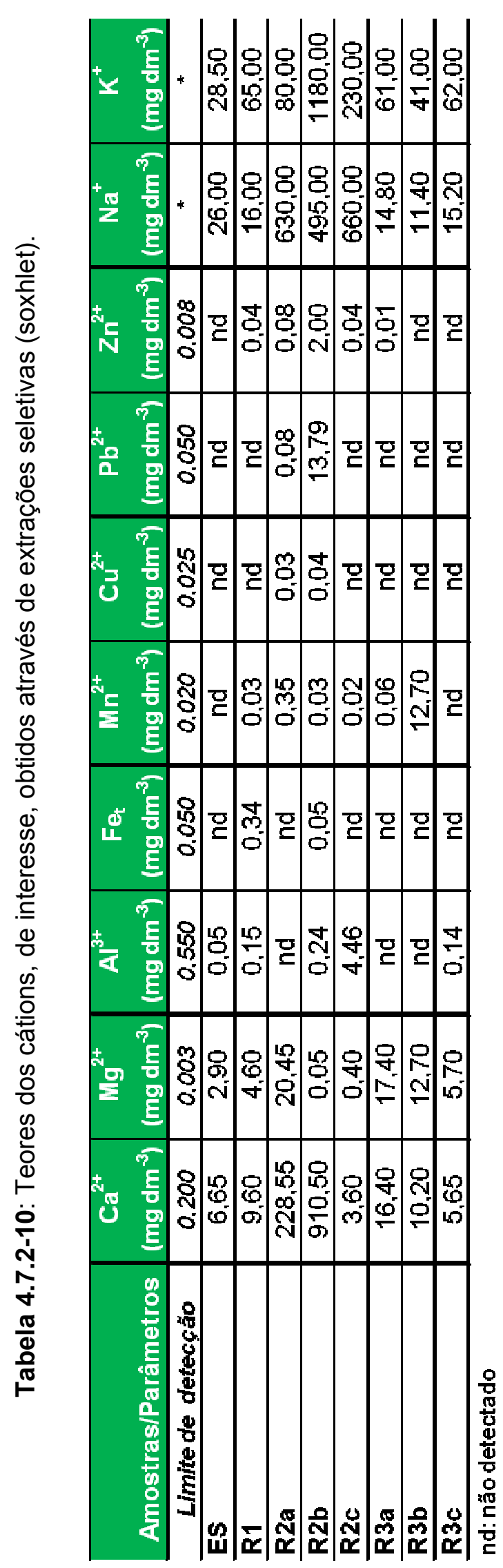


Tabela 4.7.2-11:Teores dos ânions, de interesse, obtidos através de extrações seletivas (soxhlet)

\begin{tabular}{l|c|c}
\hline \multicolumn{1}{c|}{ Amostras/Parâmetros } & $\begin{array}{c}\mathrm{Cl}^{-} \\
\left(\mathrm{mg} \mathrm{dm}^{-3}\right)\end{array}$ & $\begin{array}{c}\mathrm{SO}_{4}^{-} \\
\left(\mathrm{mg} \mathrm{dm}^{-3}\right)\end{array}$ \\
\hline Limite de detecção & 0,070 & 0,020 \\
\hline $\mathbf{E S}$ & 52,490 & 25,290 \\
\hline $\mathbf{R 1}$ & 23,510 & 28,740 \\
\hline $\mathbf{R 2 a}$ & 1163,200 & 298,860 \\
\hline R2b & 1249,300 & 644,090 \\
\hline R2c & 705,910 & 382,430 \\
\hline R3a & 99,550 & 0,810 \\
\hline R3b & 22,670 & 25,500 \\
\hline R3c & 24,860 & 31,780 \\
\hline
\end{tabular}

As soluções lixiviadas permitiram a compreensão dos mecanismos hidrogeoquímicos associados às transformações conseqüentes da disposição de resíduos na área do aterro nas águas superficiais e subterrâneas adjacentes.

Esses cátions, dependendo do $\mathrm{pH}$ do meio, podem fixar-se nos solo/sedimentos sob as formas de óxidos/hidróxidos e carbonatos ou disponibilizarem-se nas soluções.

O ferro metálico ocupa a maior parte dos resíduos, inicialmente com a presença de $\mathrm{O}_{2}$ do ar e água oxida-se a $\mathrm{Fe}^{2+}$ e em seguida a $\mathrm{Fe}^{3+}$.

$$
\begin{aligned}
& \mathrm{Fe}(\mathrm{s}) \stackrel{\hookrightarrow}{\rightarrow} \mathrm{Fe}^{2+}(\mathrm{aq})+2 \mathrm{e} \\
& \mathrm{Fe}^{2+}(\mathrm{aq}) \stackrel{\leftarrow}{\longrightarrow} \mathrm{Fe}^{3+}(\mathrm{aq})+1 \mathrm{e}
\end{aligned}
$$

Como o $\mathrm{S}^{2-}$ é um agente redutor, tem-se facilitada a formação de $\mathrm{Fe}^{2+}$ que é a forma segundo a qual o ferro torna-se disponibilizado ao meio ambiente. O meio ligeiramente ácido que domina o ambiente da área, devido principalmente a hidrólise do $\mathrm{Fe}^{3+}$, vem facilitar a liberação do $\mathrm{Fe}^{2+}$.

$$
\mathrm{Fe}^{3+}(\mathrm{aq})+\mathrm{H}_{2} \mathrm{O}(\mathrm{l}) \stackrel{\leftarrow}{\longrightarrow} \mathrm{Fe}(\mathrm{OH})_{3}(\mathrm{~s})+\mathrm{H}^{+}(\mathrm{aq})
$$


Por outro lado, a precipitação do ferro, que pode levar a forma de óxido/hidróxido, explica seus teores relativamente baixos nas soluções lixiviadas.

Nos resíduos, o manganês encontra-se em três estados de valência: $\mathrm{Mn}^{+2}$ (como cátion adsorvido ou em solução), $\mathrm{Mn}^{+3}$ (como trióxido de manganês, bastante reativo) e $\mathrm{Mn}^{+4}$ (como dióxido de manganês muito estável). Essas três formas encontram-se em equilíbrio dinâmico, em que a ocorrência de $\mathrm{Mn}^{+3} \mathrm{e} \mathrm{Mn}^{+4}$ é favorecida pela elevação do $\mathrm{pH}$ e condições oxidantes e a de $\mathrm{Mn}^{+2}$ em meios com pH baixo e condições redutoras (Hypolito, 1993 e Nascimento et. al., 2006).

O chumbo encontra-se predominantemente na forma metálica, podendo encontrar-se também como sulfetos, óxidos, carbonatos etc.

Apesar de tratar de compostos pouco solúveis, a reação de água sobre os resíduos produz hidróxidos, carbonatos e mesmo $\mathrm{Pb}^{2+}$ que é a forma mais estável em solução.

Com isto, de um lado, a hidrólise do $\mathrm{Fe}^{3+}$ diminui o $\mathrm{pH}$, a do $\mathrm{S}^{2-}$ em $\mathrm{H}_{2} \mathrm{O}$ produz $\mathrm{OH}^{-}$e, sendo assim, a dissolução dos compostos de chumbo, cobre e zinco, dependerão especialmente dessas duas reações químicas.

$$
\begin{aligned}
& \mathrm{PbCO}_{3}(\mathrm{~s})+2 \mathrm{H}^{+}(\mathrm{aq}) \stackrel{\leftarrow}{\rightarrow} \mathrm{Pb}^{2+}(\mathrm{aq})+\mathrm{H}_{2} \mathrm{O}(\mathrm{l})+\mathrm{CO}_{2}(\mathrm{~g}) \\
& \mathrm{PbS}(\mathrm{s})+2 \mathrm{H}^{+}(\mathrm{aq}) \stackrel{\leftrightarrows}{\leftrightarrows} \mathrm{Pb}^{2+}(\mathrm{aq})+\mathrm{H}_{2} \mathrm{~S}(\mathrm{~g}) \\
& \mathrm{Pb}(\mathrm{OH})(\mathrm{s})+2 \mathrm{H}^{+}(\mathrm{aq}) \stackrel{\mathrm{Pb}^{2+}}{(\mathrm{aq})}+\mathrm{H}_{2} \mathrm{O}(\mathrm{l})
\end{aligned}
$$

O cobre e o zinco encontram-se fortemente ligados aos resíduos sob a forma metálica, provavelmente como ligas e também terão sua disponibilidade em função da hidrólise do ferro e sulfeto.

Em relação à mobilidade destes elementos nas pilhas de resíduos observase, de maneira geral, maior disponibilidade na porção mais aerada (topo e meio), provavelmente devido à presença de $\mathrm{CO}_{2}$ atmosférico, e também pela disponibilidade de $\mathrm{SO}_{4}{ }^{2-}$. 
Por outro lado na base, além da ausência de $\mathrm{CO}_{3}{ }^{2-}$, a liberação de $\mathrm{SO}_{4}{ }^{-2}$ é menor, indicando a presença destes íons na forma precipitada.

O comportamento dos ânions $\mathrm{SO}_{4}{ }^{2-}, \mathrm{Cl}^{-}$, estudado através da solução lixiviada, constata-se que eles são mais eliminados no topo em relação à base.

\subsubsection{Atividade}

As leis químicas são sempre validas para soluções que se encontram no estado de equilíbrio e na forma diluída. No equilíbrio porque, nesta condição, se têm valores fixos dos parâmetros envolvidos nas reações químicas e diluídas porque, desta forma, os íons em solução apresentam-se hidratados e não sofrem, ou sofrem muito pouca influência dos íons vizinhos.

Numa solução concentrada, devido à interação entre os íons, ocorre menor mobilidade iônica e os pares de íons comportam-se como partículas não totalmente ionizadas, produzindo desvios acentuados do comportamento ideal das soluções, neste caso, a concentração iônica é menor que a concentração analítica, aquela preparada em laboratório.

A interferência dos íons entre si, quando as soluções não são suficientemente diluídas, obriga, ao invés de concentração, o uso de atividade, que é a concentração efetiva dos íons em solução.

Assim, dados analíticos com concentrações superiores a $10^{-4} \mathrm{M}$ devem ser tratados em termos de atividade e não como soluções comuns, ideais (Thobanoglous et al., 1993). 
A equação que permite o cálculo da atividade (a) é :

$$
a=\gamma C
$$

$\gamma$ - coeficiente de atividade

C- concentração analítica

Para cálculos do coeficiente de atividade dos íons individualmente pode ser utilizada a equação de Debye-Huckel (1932) apud Pierangeli et. al.,2001:

$$
\log \gamma=\frac{A Z_{i}^{2} \sqrt{1}}{1+a_{1}^{0} B \sqrt{1}}
$$

A e B: constantes que dependem da temperatura absoluta, da constante dielétrica e da natureza do solvente. Para a água a $1 \mathrm{~atm}$ e $25^{\circ} \mathrm{C}$, A é igual a 0,51 $\left(\mathrm{mol}^{1 / 2} \mathrm{x} \mathrm{dm}^{-1 / 2}\right)$ e B $0,33\left(2,510^{-8}\right.$ a $\left.1110^{-8} \mathrm{~cm}\right)$.

$Z_{\mathrm{i}}$ : carga dos íons

$a^{0}:$ refere-se ao tamanho efetivo (diâmetro) do íons hidratado

I: força iônica

O coeficiente de atividade varia de acordo com a concentração. Esta variação é complexa, onde o coeficiente de atividade de um íon específico depende da concentração de todos os componentes iônicos em solução. A força iônica (I) foi estimada como a semi-soma dos produtos da concentração de cada íon multiplicado pelo quadrado de sua carga (Lewis e Radall, 1921 in Vogel, 1981): 


$$
I=1 / 2 \sum c_{i} z_{i}^{2}
$$

$\mathrm{c}_{\mathrm{i}}$ : concentração do igésimo componente

$\mathrm{z}_{\mathrm{i}}$ : é sua carga

Griffin \& Jurinak, 1973 In Lindsay, 1979 estimaram a força iônica (I) pela relação:

\section{$\mathrm{I}=\mathbf{0 , 0 1 3} \times \mathrm{CE}$}

I: força iônica $\left(\mathrm{mol} \mathrm{dm}^{-3}\right)$

$\mathrm{CE}$ : condutividade elétrica $\left(\mathrm{mS} \mathrm{cm}^{-1}\right.$ )

A solubilidade de espécies químicas que se encontram em contato com a solução é influenciada pela força iônica do meio. Assim, o aumento da força iônica redunda na diminuição do coeficiente de atividade e, desta forma, aumenta a solubilidade do material sólido.

Neste trabalho, devido à área de estudo localizar-se em região de manguezal com influência de água do mar apresenta grandes variações de salinidade que, por sua vez, traduzem em alterações na força iônica.

O estudo do efeito da força iônica na liberação de íons de metais pesados para o meio ambiente na área do Aterro Industrial, foi realizado através de ensaios laboratoriais, utilizando resíduos oriundos dos processos siderúrgicos e soluções com forças iônicas variadas.

Calculou-se a força iônica de cada ponto de amostragem de água subterrânea através da equação desenvolvida por Griffin \& Jurinark, 1973 (op. 
cit.), a fim de se obter valor médio para a força iônica da área do Aterro (Tabela 7.7.3-1.).

Tabela 7.7.3-1.: Valores de Força lônica (I) calculados para a água subterrânea coletada em poços de monitoramento na área do Aterro Industrial.

\begin{tabular}{|c|c|c|c|c|c|}
\hline Parâmetros & PM1 & $\overline{\mathrm{PM} 2}$ & PM3 & $\overline{\mathrm{PM} 4}$ & PM5 \\
\hline $\mathrm{CE}\left(\mathrm{mS} \mathrm{cm}^{-1}\right)$ & 20,90 & 23,50 & 26,50 & 8,91 & 18,30 \\
\hline I( mol L-1) & 0,27 & 0,31 & 0,34 & 0,12 & 0,24 \\
\hline
\end{tabular}

Para os ensaios foram utilizadas água destilada (AD), solução com valor médio de a força iônica calculada á partir das amostras de águas subterrâneas (IM) e água do mar (AM).

É importante destacar que para uniformização dos resultados foram utilizados para os ensaios 5 litros de água destilada, 5 litros da solução com força iônica média e ajustado pH com valor médio das amostras de água subterrânea da área $(7,89)$ e 5 litros de água do mar coletados em local próximo à área de estudos. A água do mar foi analisada por espectofotometria de absorção atômica e cromatografia líquida, para determinação das concentrações dos íons de interesse, cujos resultados encontram-se, respectivamente, nas Tabelas 7.7.3-2. e 7.7.3-3, respectivamente.

Tabela 7.7.3-2: Análise Química $\left(\mathrm{mg} \mathrm{dm}^{-3}\right)$ da água do mar (AM) coletada próxima á área de estudos utilizada nos ensaios laboratorias .

\begin{tabular}{l|c|c|c|c|c}
\multicolumn{1}{c|}{ Parâmetros } & $\mathrm{Cl}^{-}$ & $\mathrm{SO}_{4}{ }^{-2}$ & $\mathrm{Fe}_{\mathrm{t}}$ & $\mathrm{Mn}^{2+}$ & $\mathrm{Pb}^{2+}$ \\
\hline Lim. Detec. & 0,013 & 0,002 & 0,006 & 0,002 & 0,010 \\
\hline AM & 23363,00 & 2844,00 & $\mathrm{nd}$ & 0,12 & 0,13 \\
\hline
\end{tabular}

nd: não detectado 
Tabela 7.7.3-3.: Valores de potencial hidrogeniônico $(\mathrm{pH})$, potencial redox (Eh), condutividade elétrica (CE) e força iônica (I) das soluções em contato com os resíduos em experimentos sobre comportamento sólido/solução.

\begin{tabular}{c|c|c|c}
\hline Soluções & $\mathrm{pH}$ & $\mathrm{CE}\left(\mathrm{mS} \mathrm{cm}^{-1}\right)$ & $\mathrm{I}\left(\mathrm{mol} \mathrm{L-}{ }^{1}\right)$ \\
\hline AD (Água Destilada) & 5,860 & 0,003 & 0,00004 \\
\hline IM (força iônica média) & 7,89 & 19,62 & 0,25506 \\
\hline AM (água do mar) & 8,17 & 51,7 & 0,67210 \\
\hline
\end{tabular}

Foram moídas a 200 mesh $50 \mathrm{~g}$ (pesadas até a quarta decimal) de amostras de escória (ES), lodo (LD) depositado no fundo do tanque de coleta de percolado da célula do aterro, material depositado na célula do aterro (R1), amostras da pilha de resíduo de lama de aciaria (R2- topo, meio e base) e amostra composta da pilha de resíduo de material grosseiro contendo escória na sua constituição (R3topo, meio e base). Amostras de solos/sedimentos associados aos poços de monitoramento (S1 a S4) foram mantidos, sob agitação constante por um período de 24 horas, em contato com as soluções (AD, IM e AM) (Figura 7.7.3-1.).

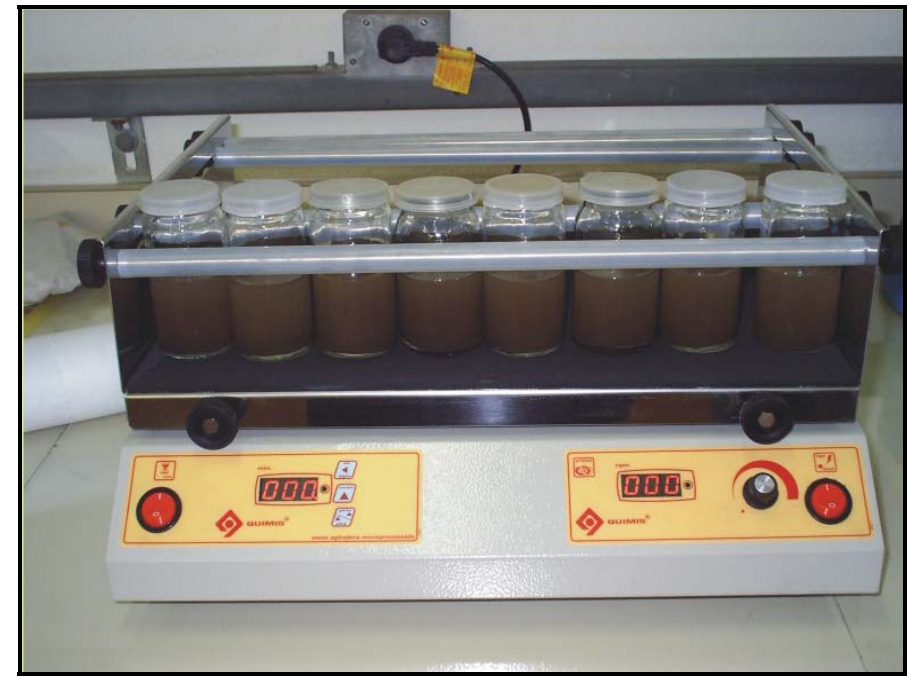

Figura 7.7.3-1.: Agitador horizontal com amostras de resíduos siderúrgicos em contato com soluções com forças iônicas variadas (AD, IM e AM). 
Após o período de agitação mediram-se os valores de pH e CE e em seguida as soluções foram filtradas (Millipore $0,45 \mu \mathrm{m}$ ), acidificadas e analisadas quimicamente por espectrofotometria de absorção atômica de chama e cromatografia líquida.

Os resultados experimentais, monitoramento analítico, cálculo de força iônica e $\Delta \mathrm{pH}$ encontram-se nas Tabelas 7.7.3-4, 7.7.3-5 (a, b) e 7.7.3-6, respectivamente.

Tabela 7.7.3-4.: pHs finais e respectivas condutividade elétrica $\left(\mathrm{mS} \mathrm{cm}^{-1}\right)$ em ensaios de sólidos/soluções com força iônica variada

\begin{tabular}{|c|c|c|c|c|c|c|}
\hline \multirow[t]{2}{*}{ Amostras } & \multicolumn{2}{|c|}{ Água Destilada (AD) } & \multicolumn{2}{|c|}{$\begin{array}{l}\text { Solução com força } \\
\text { iônica média (IM) }\end{array}$} & \multicolumn{2}{|c|}{ Água do Mar (AM) } \\
\hline & $\mathrm{pH}$ & CE & $\mathrm{pH}$ & CE & $\mathrm{pH}$ & $\mathrm{CE}$ \\
\hline Escória (ES) & 12,30 & 1,63 & 12,53 & 33,00 & 9,86 & 51,80 \\
\hline Lodo (LD) & 9,89 & 0,15 & 11,87 & 30,20 & 8,47 & 52,10 \\
\hline Célula do Aterro (R1) & 12,25 & 2,71 & 12,48 & 33,90 & 9,98 & 52,10 \\
\hline Pilha de lama aciaria (R2) & 9,3 & 0,32 & 12,26 & 30,60 & 10,17 & 52,20 \\
\hline Pilha de resíduos com escória (R3) & 12,13 & 1,67 & 12,26 & 32,60 & 10,17 & 52,20 \\
\hline Solo associado PM-1 (S1) & 10,98 & 0,24 & 11,77 & 30,70 & 9,16 & 51,90 \\
\hline Solo associado PM-2 (S2) & 9,57 & 0,18 & 11,27 & 30,40 & 8,92 & 52,00 \\
\hline Solo associado PM-3 (S3) & 12,14 & 1,13 & 12,05 & 31,90 & 9,96 & 52,00 \\
\hline Solo associado PM-4 (S4) & 11,88 & 32,6 & 12,40 & 32,60 & 9,98 & 52,00 \\
\hline
\end{tabular}

Tabela 7.7.3-5.a: Monitoramento analítico dos cátions $\left(\mathrm{mg} \mathrm{dm}^{-3}\right)$ em ensaios de força iônica nas amostras de resíduos siderúrgicos e solos/sedimentos associados ao poços de monitoramento da área do Aterro Industrial

\begin{tabular}{|c|c|c|c|c|c|c|c|c|c|}
\hline \multirow{2}{*}{ Amostras } & \multicolumn{3}{|c|}{ Água Destilada (AD) } & \multicolumn{3}{|c|}{ Solução com força iônica média (IM) } & \multicolumn{3}{|c|}{ Agua do Mar (AM) } \\
\hline & $\mathrm{Fe}_{\mathrm{t}}$ & $\mathrm{Mn}^{2+}$ & $\mathrm{Pb}^{2+}$ & $\mathrm{Fe}_{\mathrm{t}}$ & $\mathrm{Mn}^{2+}$ & $\mathrm{Pb}^{2+}$ & $\mathrm{Fe}_{\mathrm{t}}$ & $\mathrm{Mn}^{2+}$ & $\mathrm{Pb}^{2+}$ \\
\hline Escória (ES) & 2,93 & 0,21 & 0,00 & 3,16 & 0,99 & 0,00 & 21,65 & 1,14 & 0,39 \\
\hline Lodo (LD) & 0,07 & 0,03 & 0,00 & 3,05 & 0,22 & 0,00 & 1,00 & 0,46 & 0,20 \\
\hline Célula do Aterro (R1) & 0,53 & 0,11 & 0,00 & 3,71 & 0,12 & 0,00 & 2,01 & 0,11 & 1,85 \\
\hline Pilha de lama aciaria (R2) & 4,75 & 0,13 & 0,02 & 4,34 & 0,19 & 0,39 & 5,74 & 0,33 & 2,03 \\
\hline Pilha de resíduos com escória (R3) & 0,12 & 0,06 & 0,00 & 0,00 & 0,02 & 0,00 & 1,49 & 0,09 & 0,48 \\
\hline Solo associado ao PM-1 (S1) & 4,63 & 0,56 & 0,00 & 4,47 & 0,39 & 0,00 & 12,63 & 0,81 & 0,00 \\
\hline Solo associado ao PM-2 (S2) & 13,64 & 0,25 & 0,00 & 18,35 & 0,35 & 0,20 & 77,13 & 0,19 & 2,50 \\
\hline Solo associado ao PM-3 (S3) & 2,91 & 0,64 & 0,00 & 0,90 & 0,02 & 0,00 & 0,61 & 0,15 & 3,73 \\
\hline Solo associado ao PM-4 (S4) & 3,45 & 0,49 & 0,00 & 2,41 & 0,28 & 0,00 & 0,61 & 0,15 & 3,73 \\
\hline
\end{tabular}


Tabela 7.7.3-5.b: Monitoramento analítico dos ânions $\left(\mathrm{mg} \mathrm{dm}^{-3}\right)$ em ensaios de força iônica nas amostras de resíduos siderúrgicos e solos/sedimentos associados ao poços de monitoramento da área do Aterro Industrial

\begin{tabular}{l|c|c|c|c|c|c}
\multirow{2}{*}{ Amostras } & \multicolumn{2}{|c|}{$\begin{array}{c}\text { Água Destilada } \\
\text { (AD) }\end{array}$} & \multicolumn{2}{c|}{$\begin{array}{c}\text { Solução com força } \\
\text { iônica média (IM) }\end{array}$} & \multicolumn{2}{c}{ Água do Mar (AM) } \\
\cline { 2 - 7 } & $\mathrm{Cl}^{-}$ & $\mathbf{S O}_{4}{ }^{2-}$ & $\mathrm{Cl}^{-}$ & $\mathbf{S O}_{4}{ }^{2-}$ & $\mathrm{Cl}^{-}$ & $\mathbf{S O}_{4}{ }^{2-}$ \\
\hline Escória (ES) & 10,90 & 12,40 & 7477,00 & 23,40 & 10550,00 & 578,00 \\
\hline Lodo (LD) & 155,00 & 24,90 & 6540,00 & 30,30 & 11081,00 & 684,00 \\
\hline Célula do Aterro (R1) & 57,80 & 35,80 & 5389,00 & 73,10 & 10944,00 & 565,00 \\
\hline Pilha de lama aciaria (R2) & 25,50 & 56,50 & 4894,00 & 65,90 & 11069,00 & 120,00 \\
\hline Pilha de resíduos com escória (R3) & 20,20 & 6,50 & 11180,00 & 22,20 & 19810,00 & 840,00 \\
\hline Solo associado ao PM-1 (S1) & 7,60 & 2,80 & 10889,00 & 5,00 & 21085,00 & 561,00 \\
\hline Solo associado ao PM-2 (S2) & 181,00 & 8,60 & 4409,00 & 13,50 & 11205,00 & 403,00 \\
\hline Solo associado ao PM-3 (S3) & 13,90 & 10,00 & 4126,00 & 25,90 & 10614,00 & 403,00 \\
\hline Solo associado ao PM-4 (S4) & 156,20 & 2,00 & 4797,00 & 12,40 & 10914,00 & 431,00 \\
\hline
\end{tabular}

Tabela 7.7.3-6.: Força iônica $\left(\mathrm{mol} \mathrm{dm}^{-3}\right)$ e $\Delta \mathrm{pH}$ de soluções obtidas em ensaios de resíduos do Aterro Siderúrgico com força iônica variada.

\begin{tabular}{|c|c|c|c|c|c|c|}
\hline \multirow[t]{2}{*}{ Amostras } & \multicolumn{2}{|c|}{ Água Destilada (AD) } & \multicolumn{2}{|c|}{$\begin{array}{c}\text { Solução com força iônica } \\
\text { média (IM) }\end{array}$} & \multicolumn{2}{|c|}{ Água do Mar (AM) } \\
\hline & I & $\Delta \mathrm{pH}$ & 1 & $\Delta \mathrm{pH}$ & I & $\Delta \mathrm{pH}$ \\
\hline Escória (ES) & 0,0200 & 6,440 & 0,4300 & 4,650 & 0,6700 & 1,690 \\
\hline Lodo (LD) & 0,0020 & 4,030 & 0,3900 & 3,990 & 0,6800 & 0,300 \\
\hline Célula do Aterro (R1) & 0,0350 & 6,390 & 0,4400 & 4,600 & 0,6800 & 1,810 \\
\hline Pilha de lama aciaria (R2) & 0,0003 & 3,440 & 0,4000 & 4,380 & 0,6800 & 2,000 \\
\hline Pilha de resíduos com escória (R3) & 0,0200 & 6,270 & 0,4200 & 4,380 & 0,6800 & 2,000 \\
\hline Solo associado ao PM-1 (S1) & 0,0030 & 5,120 & 0,4000 & 3,890 & 0,6700 & 0,990 \\
\hline Solo associado ao PM-2 (S2) & 0,0020 & 3,710 & 0,4000 & 3,390 & 0,6800 & 0,750 \\
\hline Solo associado ao PM-3 (S3) & 0,0150 & 6,280 & 0,4100 & 4,170 & 0,6800 & 1,790 \\
\hline Solo associado ao PM-4 (S4) & 0,0300 & 6,020 & 0,4200 & 4,520 & 0,6800 & 1,810 \\
\hline
\end{tabular}

$\mathrm{O} \mathrm{pH}$ aparece como um dos principais fatores reguladores da solubilidade $\mathrm{e}$ disponibilidade dos íons nas soluções; se o pH final for maior que o inicial significa que o fenômeno ocorreu com o consumo de $\mathrm{H}^{+}$. Pelos valores de $\Delta \mathrm{pH}$ constatase que na solução com água pura (AD) ocorreu maior consumo de $\mathrm{H}^{+}$e o menor foi observado na solução com água do mar (AM).

Os dados experimentais demonstraram a forte influência da salinidade na disponibilidade iônica na área do aterro - obteve-se em todos os experimentos maior mobilidade com força iônica elevada, ou seja, com água do mar. 
O comportamento dos íons de todo o material disposto no aterro acha-se intimamente associado à liberação de ferro e enxofre que, por sua vez dependem dos potenciais normais de óxido redução $\left(\mathrm{E}^{0}\right)$ e dos fenômenos de hidrólise.

Os elevados teores de sulfato nas soluções indicam maiores teores de sulfeto nos materiais e, portanto, ambiente mais redutor.

O ferro em relação ás forças iônicas comportou-se de modo variado, ora mais solúvel como quando em contato com a água do mar, ora apresentou baixa mobilidade com água pura e com força iônica média.

O manganês mostrou comportamento semelhante ao do ferro, ou seja, em condições de menor consumo de $\mathrm{H}^{+}$( $\mathrm{pH}$ elevado) teve facilitadas às formações de óxidos-hidróxidos de manganês.

O chumbo em meio fortemente alcalino pode se dissolver produzindo plumbito $([\mathrm{PbOOH}])$, todavia, com facilidade, precipita na forma de carbonato, cloreto, sulfato e sulfeto. Estas observações levam a conclusão de que o chumbo é praticamente fixo junto aos materiais dispostos no aterro e sua disponibilidade ocorre devido à força iônica elevada da água do mar. A liberação de chumbo na amostra da pilha de resíduos R2 ocorreu por se tratar de lama de aciaria constituída de material extremamente fino com elevada superfície específica. 


\section{CONCLUSÃO}

A área de estudos, por tratar-se de um aterro formado pela deposição de materiais siderúrgicos com características bastante diversificadas, a área de estudos, constitui-se num sistema extremamente complexo para estudos da disponibilidade iônica ao meio ambiente.

Os resultados químicos, físico-químicos, mineralógicos e texturais das amostras sólidas coletadas na área do aterro e na margem do Rio Piaçaguera foram detalhadamente correlacionadas com as águas subterrâneas, superficiais e efluentes.

As principais fontes de poluição da área de estudos consistem de resíduos ricos em ferro, manganês e, em menores proporções, fazendo parte, na maioria das vezes, de materiais amorfos, chumbo, zinco, cobre e compostos de enxofre.

O material sólido original é constituído em sua grande parte por metais em mistura com sulfetos e óxidos e a disponibilidade iônica desse material foi quantificada através de extrações nítricas que indicaram tratar-se de fonte de emissão difusa de metais pesados nocivos ao meio ambiente.

O ferro metálico do resíduo exposto às intempéries sofre oxidação produzindo ferro (II) e ferro (III) que se hidrolisa transformando-se em hidróxido passando, posteriormente, a óxidos/hidróxidos pela perda de água. A hidrólise do ferro (III) ocorre com produção de $\mathrm{H}^{+}$baixando acentuadamente o $\mathrm{pH}$.

Outros componentes de relevância são os compostos de enxofre especialmente sulfetos. Eles apresentam características redutoras, oxidam-se a sulfato, facilitando a formação de ferro em grau de oxidação mais baixo como ferro (II), mais móvel. Os sulfetos também sofrem hidrólise, contudo, contrariamente ao ferro (III), a reação com água faz com que aumente o $\mathrm{pH}$. A alta concentração de compostos de enxofre, proveniente do próprio ambiente de manguezal como também de impurezas dos minérios utilizados, pôde ser constatada pela presença de gás sulfídrico, facilmente identificada pelo forte odor característico em toda área. 
A presença do manganês, terceiro componente de relevância dos resíduos, está relacionada às reações que envolvem oxidações do ferro e sulfetos, que o estabiliza na sua forma mais solúvel que é a de manganês (II).

$\mathrm{O}$ chumbo, zinco e cobre, nas condições reinantes de pH, encontram-se predominantemente na forma insolúvel como sulfetos, óxidos, hidróxidos, carbonatos e mesmo em solução como íons simples ou complexados.

Em todos os poços de monitoramento, exceto PM4, o bicarbonato é dominante na forma de carbono inorgânico dissolvido e assim, teores de condutividade elétrica são elevados. Em águas com pH maior que 10, como em PM4, o íon carbonato transforma-se em espécie dominante, apresentando, nestes pontos, baixos valores de condutividade elétrica, indicando precipitação de íons metálicos na forma de carbonato e/ou óxidos/hidróxidos.

Os dados químicos e físico-químicos das águas subterrâneas associadas aos pontos de coleta dos materiais sólidos indicaram baixa mobilidade iônica que, no entanto, em função das condições ambientais, fornecem intermitentemente íons poluentes ao ambiente. Desta forma, o comportamento iônico deve-se principalmente aos fatores $\mathrm{pH}$ e Eh do sistema sólido/solução.

Se, de um lado, o ambiente de estudos apresentou pH médio próximo de 8 , o que facilita formação de compostos pouco solúveis, de outro, devido as condições redutoras, tem-se facilitada a mobilidade de íons como de ferro (II) e manganês (II). Sendo os teores destes íons nas águas dos poços pouco significativos podese concluir que o pH é o parâmetro dominante que imprime estabilidade aos produtos neoformados insolúveis. Este fato é evidenciado ao se compararem os dados analíticos das soluções e lodo do tanque de captação de efluentes das células e das soluções de drenagem do aterro. As primeiras, sujeitas apenas às águas de chuva, com pH superior a 9, têm precipitados contendo carbonatos, óxidos/hidróxidos de alumínio, ferro, cobre chumbo etc. e a solução em equilíbrio com esses sólidos praticamente isenta de íons de metais pesados. 
Os resíduos do aterro, não pertencente às células, sujeitos às intempéries e variações das marés, produzem altas concentrações de cloretos, sulfatos e valores baixos em ferro, manganês, chumbo e zinco.

Os resíduos descartados, apesar de estáveis, encontram-se submetidos a um contínuo processo dinâmico sujeitos a expressivas modificações graças à ação das águas pluviais e às variações das marés. A influência desses dois parâmetros foi estudada simulando lixiviações pluviométricas através de extrator do tipo sohxlet, em experimentos com água saturada em $\mathrm{CO}_{2}\left(70^{\circ} \mathrm{C}\right)$ e submetendo os sólidos sob diferentes condições de salinidade.

Os experimentos que simularam a ação das águas de chuvas nos resíduos revelaram mobilidades significativas apenas dos constituintes mais solúveis como sódio, potássio, cálcio e magnésio.

Os resíduos do aterro em contato com as soluções com forças iônicas variadas, que simularam o contato do material sólido com solução das marés, produziram maior mobilidade na solução com força iônica mais elevada, isto é nos ensaios realizados com água do mar.

Em todo o aterro os resíduos sofrem, nas marés baixas, influência de água salobra e da água salgada nos períodos das marés altas.

Esses experimentos permitiram concluir a pouca influência das águas de chuvas na mobilidade iônica dos resíduos do aterro e que os principais fatores de dissolução e mobilidade são representados pelo $\mathrm{pH}$ do meio e variação do nível d'água sob influência das marés.

Na margem do Rio Piaçaguera foi detectado acúmulo de materiais carreados dos resíduos depositados no aterro e a contribuição iônica do aterro para o Rio, foi comprovada pelas análises químicas dos sedimentos da margem e águas coletadas a montante e a jusante nos limites do aterro.

Os resultados indicaram que a contribuição de cada material do aterro, apesar de características diferenciadas, cuja estabilidade é função das condições do meio, representam perigo potencial com risco de bioacumulação dos íons 
contaminantes nos organismos, expondo a população ribeirinha ao consumo de pescado, crustáceos e outros organismos comprometidos pela poluição.

Sendo a variação do $\mathrm{pH}$ do sistema estudado um dos principais fatores que regulam a migração iônica, uma das possibilidades de remediação/mitigação pode ser sua manutenção em valores superiores a 8 . Assim, seria recomendável a construção de uma barreira reativa permeável formada por calcário nos limites do aterro na margem direita do Rio Piaçaguera. 


\section{REFERÊNCIAS BIBLIOGRÁFICAS}

ALLOWAY, R.J. Heavy Metals in Soils. London, Blackie Academic \& Professional, 368p., 1995.

AMARAL, P.G.C. Contribuição Palinológica ao Estudo da evolução do manguezal do Rio Itanhaém, litoral sul de São Paulo. 2003. 71 p. Dissertação (Mestrado) - Instituto de Geociências Universidade de São Paulo, São Paulo, 2003.

ANJOS, J.A.S. A. Avaliação da eficiência de uma zona alagadiça (wetland) no controle da poluição por metais pesados: O caso da Plumbum em Santo Amaro da Purificação/BA. 2003. 328 p. Tese (Doutorado)- Escola PolitécnicaDepartamento de Engenharia de Minas e de Petróleo da Universidade de São Paulo, São Paulo, 2003.

ASSOCIAÇÃO BRASILEIRA DE NORMAS TÉCNICAS (ABNT) Resíduos Sólidos - Classificação. NBR-10004. São Paulo: ABNT. 1987.

ASSOCIAÇÃO BRASILEIRA DE NORMAS TÉCNICAS (ABNT). Lixiviação de Resíduos. NBR-10005. São Paulo: ABNT. 1987.

ASSOCIAÇÃO BRASILEIRA DE NORMAS TÉCNICAS (ABNT). Solubilização de resíduos - Procedimentos. NBR-10006. São Paulo: ABNT. 1987.

AZEVEDO, F.A.; CHASIN, A.A.M. Metais: Gerenciamento e Toxicidade. Editora Atheneu São Paulo. 554 p., 2003.

BARCELLOS, R.G.S., SILVA-FILHO, E.V., SELLA, S.M., BARCELLOS, P.M.S. E SANTELLI, R. E. Geoquímica de $\mathrm{Fe}$ e $\mathrm{Mn}$ em águas subterrâneas em ambientes de manguezal. In: Anais do X Congresso Brasileiro de Geoquímica e II Simpósio de Geoquímica dos Paises do Mercosul. 2005, Porto de Galinhas. 2005.

BARCELOUX, D.G. Manganese. Clin. Toxicol., New York, v.37, n.2, p.293-307, 1999. 
BARCELOUX, D.G. Copper. Clin. Toxicol., New York, v.37, n.2, p.217-230, 1999.

BARCELOUX, D.G. Zinc. Clin. Toxicol., New York, v.37, n.2, p.279-292, 1999.

BECKETT, P. H. T. The Use Extractants in Studies on Trace Metals in Soils, Sewage Sludges, and Sludge-Treated Soils. Springer - Verlag New York Inc. Advandces in soil Science, v. 9 p. 144-176, 1989.

BORMA, L.S. Acidificação e Liberação de Metais Pesados em Sedimentos Dragados Ricos em Sulfetos de Ferro: Estudo de Caso do Sistema Lagunar de Jacarepaguá/RJ. 1998. Tese (Doutorado)- COPPE/UFRJ, Rio de Janeiro, 1998.

BROKINS, D.G. Eh-ph diagrams for geochemistry. Berlin : Springer, 176 p., 1988.

BURGUESS, W.A. Recognition of health hazards in industry. A rewiew of materials and process. 3. ed.: New Jersey John Wilwy \& Sons. 538 p., 1995.

CALMANO, W., HONG, J., FÖRSTNER, U. Binding and Mobilization of Heavy Metals in Contaminated Sediments Affected by $\mathrm{pH}$ and Redox Potential. Water Science and Technology, v. 28, n 8-9, p. 223-235, 1993.

CITRON, G., SCHEFFER-NOVELLI. Introduction a la ecologia del manglar., Montevideo, USCO-ROSTLAC . 109 p., 1983.

COMPANHIA DE TECNOLOGIA DE SANEAMENTO AMBIENTAL DO ESTADO DE SÃO PAULO. (CETESB). Sistema Estuarino de Santos e São Vicente. Relatório Final. São Paulo. 176 p., 2001.

COMPANHIA DE TECNOLOGIA DE SANEAMENTO AMBIENTAL DO ESTADO DE SÃO PAULO. (CETESB). Estabelecimento de Valores Orientadores para Solos e Águas Subterrâneas no Estado de São Paulo. Relatório Final. São Paulo. 246 p., 2005. 
COMPANHIA DE TECNOLOGIA DE SANEAMENTO AMBIENTAL DO ESTADO DE SÃO PAULO (CETESB). Disponível em: http:// www.cetesb.sp.gov.br, acessado em junho de 2007.

CONSELHO NACIONAL DO MEIO AMBIENTE. RESOLUÇÃO (CONANA) n ${ }^{0} 20$ : Estabelece a classificação das águas e os níveis de qualidade exigidos. Disponível em:<http://www.mma.gov/port/conama/res/res86/res2086.html, acessado em julho de 2007.

CONSULTORIA PAULISTA. Dragagem do Canal de Piaçaguera e gerenciamento dos pasivos ambientas. Consultoria Paulista de Estudos Ambientais S/C Ltda. 2004.

CUSTODIO,E., LHAMAS, M.R. Hidrogeologia. Barcelona: Omega, 1996.

DEUSTCH, W.J. Groundwater Geochemistry: fundamentals and applications to contamination. CRC PRESS, Boca Raton, Florida, 220 p., 1997.

ENVIRONMENT CANADÁ (EC). Canadian Sediment Quality Guidelines for the Protection of Aquatic Life. Summary Tables. Disponível em http://www.ec.gc.ca. , acessado em agosto de 1999.

ENVIRONMETAL PROTECTION AGENCY (EPA), -Stanford J. Smucker Ph.D., EPA Region 9. Technical Support Team (SFD-8-B). 75 Hawthorne Street, San Francisco, CA 94105-3901. 2004.

FERNANDES,L.D.F. Transporte de poluentes em estuarios. 2003. Trabalho Final.- Instituto Técnico Superior. Universidade Técnica de Lisboa, Lisboa, 2003.

FERREIRA, T.O. Solos de Mangue do Rio Crumahú (Guarujá-SP): pedologia e contaminação por esgoto doméstico. 2002. 113 p. Dissertação (Mestrado)Escola Superior de Agricultura Luiz de Queiroz, Universidade de São Paulo, Piracicaba, 2002.

FERRER, L.M. Fixação e Mobilidade de Espécies de Mercúrio no Sistema Sedimento/Água do Mangue no Município de Cubatão. 2001. 122 p. 
Dissertação (Mestrado)- Instituto de Geociências da Universidade de São Paulo, São Paulo, 2001.

GAMEIRO, C.A.L.P. Variação espacial e temporal do fitoplâncton do estuário do Tejo. 2000. 57 p. Relatório de estágio profissionalizante Faculdade de Ciências da Universidade de Lisboa - Departamento de Biologia Vegetal Aplicada, Lisboa, 2000.

GARRELS, R.M.; CHRIST, C.L. Solutions, Minerals and Equilibria. Harper \& Row Publishers. New York, 450 p., 1965.

GUTBERLET, J. Cubatão: Desenvolvimento, Exclusão Social e Degradação Ambiental. São Paulo: Editora da Universidade de São Paulo, Fapesp. 244 p., 1996.

HERZ, R. Manguezais do Brasil. São Paulo: IO/USP, 221 p., 1991.

HYPOLITO, R. Criptomelana - Síntese e Estabilidade. 1980. 160 p. Tese de Livre Docência, Instituto de Geociências, Universidade de São Paulo. São Paulo, 1980.

HYPOLITO, R. Geoquímica da Interação solo/rocha/água (GGE-800). Metais Pesados. Parte I. Programa de Recursos Minerais e Hidrogeologia. CEPASIGc-USP, Texto Didático, 67 p., 2007.

HYPOLITO, R., SILVA, L.H., ANDRADE, S. NASCIMENTO, S.C. EZAKI, S. Kit analítico quantitativo para determinação de alcalinidade de águas naturais. Revista da Propriedade industrial. RPI n ${ }^{0}$ 1915, 127 p., 2007.

HYPOLITO, R.; GIOVANOLI, R.; VALARELLI, J. V. E ANDRADE, S. Gênese e Paragênese dos Principais Óxidos Supérgenos de Manganês. An. Acad. Bras. Ci., 65 (4): 377-387. 1993.

INSTITUTO BRASILEIRO DE GEOGRAFIA E ESTATÍSTICA (IBGE). Disponível em : www.ibge.gov.br, acessado em agosto 2007. 
INSTITUTO DE PESQUISAS TECNOLÓGICAS (IPT). Unidades de conservação ambiental e áreas correlatas no estado de São Paulo. São Paulo. Divisão de Minas e Geologia Aplicada. v 1, 1998.

JOURNAUX, A. Carta do meio ambiente e sua dinâmica: Baixada Santista. São Paulo: CETESB 33 p., 1985.

KABATA-PENDIAS, A.; PENDIAS,H.A . Trace Elements in Soils and Plants. 2nd. ed. Boca Raton, CRC Press. 1992.

KROSCHWITZ, J.I. KRK,O. Encyclopedia of chemical tecnology. 4 th ed. New York: Jhon Wiley \& Sons,. v. 14, 1995.

LIMA, I, V.; PEDROSO, M.F. Ecotoxicologia do Ferro e seus compostos. Centro de Recursos Ambientais (BA), 111 p., 2001.

MAIA, A.D. Avaliação da Geração de Drenagem Ácida em um Solo Fabricado em Laboratório Contendo Sulfeto de Ferro e Matéria Orgânica. 2004. 213 p. Dissertação (Mestrado). COPPE/UFRJ. Rio de Janeiro, 2004.

MARQUES, J. F. Comportamento de íons $\mathrm{Pb}, \mathrm{Zn}$ e $\mathrm{Cu}$ em área impactada por escória, produto da reciclagem de baterias chumbo-ácido.2004. Dissertação (Mestrado), Instituto de Geociências, Universidade de São Paulo, 2004.

MARTINS, I; LIMA, I.V. Ecotoxicologia do Manganês e seus compostos. Centro de Recursos Ambientais (BA), 122 p., 2001.

MASSAD. F. Baixada Santista: Implicações na História Geológica no Projeto de Fundações. São Paulo. Solos e Rochas: Revista Latino Americana de Geotecnia. V.22, n 1, p. 3-49, 1999.

MATTIAZZO-PREZOTTO, M.E. Comportamento de cobre, cádmio, crômio, níquel e zinco adicionados a solos de clima tropical em diferentes valores de pH. 1994. Tese de Livre Docente da Escola Superior de Agricultura "Luiz de Queiroz", da Universidade de São Paulo, Piracicaba. 1994.

McBRIDE, M. B. Environmental Chemistry of soils. Oxford University Press. New York Toronto, p. 406, 1994. 
MERIAN. E. Metals and their compounds in the environment: occurrence, analysis and biological relevance. Weinheim: VCH, 1438 p, 1991.

NASCIMENTO, S.C.; HYPOLITO, R.; RIBEIRO, A.A. Disponibilidade de metais pesados em aterro de indústria siderúrgica. Revista Eng. Sanit. Ambiental. Rio de Janeiro. vol.11. $\mathrm{n}^{0}$.3. 2006.

NELSON, R. L.; DAVIS, F.G.; SUTTER, E.; SOBIN, L.H, KIKENDALL, J.W. BOWEN, P. Body iron stores and risk of colonic neoplasia. Journal Natl. Cancer Inst. 16,86 (6):455-60. 1994.

OLAUSSON, E. AND CATO, I. (Eds.) Chemistry and biogeochemistry of estuaries. New York, Jhon Willey and Sons, 452 p., 1980.

PAOLIELLO, M.M.B.; CHASIN, A.A.M. Ecotoxicologia do chumbo e seus compostos. Centro de Recursos Ambientais (BA), 150 p., 2001.

PIERANGELI, M.A.P., GUILHERME, L.R.G., OLIVEIRA, N.C., SILVA, M.L.N. Efeito da força iônica da solução de equilíbrio sobre a adsorção/dessorção de chumbo em Latossolos brasileiros. Pesquisa Agropecuária Brasileira, Brasília, v. 36, n8, p. 1077-1084, 2001.

PONNEMPERUMA, F.N. The chemystry of submerged soils. Advances Agronomy, v. 24, p. 29-96, 1972.

PRAKASA, R.M.; SWAMY, A.S.R. Clay mineral distribution in the mangrove of the Godavari delta. Clay Research, v. 6, n. 2, p. 81-86, 1987.

QUEVAUVILLER, PH.; RAURET,G.; SÁNCHEZ-LÓPEZ, J.F.; RUBIO, R. URE, A.; MUNTAU H. Certification of Trace Metal Extractable Contents in a Sediment Reference Material Following a Three-steps Sequential Extraction Procedure. Science of the Total Environment, v. 205, p. 223-234, 1997.

QUINÁGLIA, G.A. Estabelecimento de um protocolo analítico de preparação de amostras de solo para determinação de metais e sua aplicação em um estudo de caso. 2001. 164 p. Dissertação (mestrado)- Faculdade de Saúde Pública, Universidade de São Paulo, São Paulo, 2004. 
REINSON, G.E. Transgressive Barrier Island and Estuarine Systems. In: WALKER, R.G. \& JAMES, N.P. (Eds.) Facies models- response to sea level change. Geological Association of Canada, Ontario, 454 p, 1992.

ROMEIRO, S.B.B. Química na siderurgia. Área de educação Química. Série Química e Tecnologia. Instituto de Química. Universidade Federal do Rio Grande do Sul, 39 p,1997.

ROSS, J. L. S.; MOROZ, I. C. Mapa Geomorfológico do Estado de São Paulo. Laboratório de Geomorfologia - Dept. de Geografia - FFLCH-USP/Laboratório de Geologia Aplicada - IPT- Fapesp-- Mapas e Relatório. Escala 1:500.000, 1997.

SANTOS, A.C; COLACCIOPOS, S.; DALBÓ, C.M.R; SANTOS, N.A.G. Ocupacional exposure to lead, kidney function tests and blood pressure. Am. J. Ind. Med. v.26, p. 635-643, 1992.

SATAWATHA, N.; PATRICK JR., S.; MOORE, P.A. Effect of controlled redox conditions on metal solubility in acid sulfate soils. Plant and Soil, vol. 113,.p. 281-290,1991.

SHEPARD, F.P. Revised Nomenclature for Depositional Coastal Features. Ameri. Ass. Pet. Geol. Bull., Tulsa. v.36, nº 10, p.1902-1912, 1965.

SIENKO, M.J.; PLANE, R.A. Elementos de transição II. 5. ed. São Paulo Química.Nacional, 463 p., 1977.

SILVA I.X.; MORAES, R.P.; SANTOS, R.P.; POMPÉIA, S.L.; MARTINS, S.E. Avaliação do estado de degradação dos ecossistemas da Baixada SantistaSP. CETESB. São Paulo. 45 p., 1981.

SMITH, L.A.;MEANS,J.L.; CHEN, A.; ALLEMAN, B.; CHAPMAN, C.C.;TIXIER, JR, J.S.; BRAUNING,S.E.;GAVASKAR, A.R.; ROYER, M.D. Remedial options for metals-contaminated sites. New York, CRC Press, p. 17-33, 1995.

SPOSITO, G.;LUND, L.J.; CHANG, A.C. Trace Metal Chemistry in Arid Zone Field Soil Amended With Sewage Sludge. Fractionation of $\mathrm{Ni}, \mathrm{Cu}, \mathrm{Zn}$ and $\mathrm{Pb}$ in Solid Phases. Soil Science Society American Journal, v. 46, p. 260-264,1982. 
STUM, W.; MORGAN, J. J. Aquatic Chemistry Chemical Equilibira and Rates in Natural Waters. New York, John Wiley \& Sons. Ed. $3^{\text {nd }}, 102$ p., 1998.

SUGIO, K. Dicionário de geologia sedimentar e áreas afins. Rio de Janeiro Bertrand Brasil. 1222 p, 1998.

SUGUIO, K. MARTINS, L. Formações Quaternárias Marinhas do Litoral Paulísta e Sul Fluminense. São Paulo. In: International Symposium on Coastal Evolution in the Quaternary. Publicação Especial n ${ }^{0}$ 1, p. 11-18, 1978.

TCHOBANOGLOUS, G.; THEISEN, H.; VIGIL, S. Integrated Solid Waste Management. Engineering Principles and Management Issues. Nova lorque, McGraw-Hill. 978 p., 1993.

UKPONG, L.E. Mangrove swamp at a saline/fresh water interface near Creek Town, Southeastern Nigeria. Catena, v. 29, p. 61-71, 1997.

URE, A.; QUEVAUVILLER, PH.; MUNTAU, H; GRIEPINK, B. Speciation of Heavy Metal in Soils and Sediments. An account of the Improvement and Harmonization of Extraction Techniques Undertaken the Commission of the European Communities. Inter. J. Environ. Anal. Chem., v 51, p.135-151, 1993.

VOGEL, A.I. Química analítica qualitativa. São Paulo, Ed. Mestre Jou, 665 p., 1981.

WORLD HEALTH ORGANIZATION (WHO). Environmental Health Criteria, n.17 Manganese. Geneva. 110 p., 1981.

WORLD HEALTH ORGANIZATION (WHO). Environmental Health Criteria, n.165 - Inorganic Lead. Geneva. p. 25-35, 1995.

www.google.com, acessado em setembro, 2007.

YE, Y., TAM, N.F.X., WONG, Y.S. Liverstock wastewater treatment by a mangrove pot-cultivation system and the effect of salinity on the nutrient removal efficiency. Marine Pollution Bulletin, v.42, $\mathrm{n}^{0}$ 6, p. 513-521, 2001. 